Portland State University

PDXScholar

8-11-2005

\title{
An Assessment of the Impacts of Climate Change on the Upper Clackamas River Basin with a Distributed Hydrologic Model
}

David Graves

Portland State University

Follow this and additional works at: https://pdxscholar.library.pdx.edu/open_access_etds

Part of the Geographic Information Sciences Commons, and the Physical and Environmental Geography Commons

Let us know how access to this document benefits you.

\section{Recommended Citation}

Graves, David, "An Assessment of the Impacts of Climate Change on the Upper Clackamas River Basin with a Distributed Hydrologic Model" (2005). Dissertations and Theses. Paper 2432.

https://doi.org/10.15760/etd.2429

This Thesis is brought to you for free and open access. It has been accepted for inclusion in Dissertations and Theses by an authorized administrator of PDXScholar. Please contact us if we can make this document more accessible: pdxscholar@pdx.edu. 


\section{THESIS APPROVAL}

The abstract and thesis of David Graves for the Master of Science in Geography were presented August 11,2005, and accepted by the thesis committee and the department.

COMMITTEE APPROVALS:

Heejun Chang, Chair

Daniel Johnsón

Geoffrey Duh

Alan Yeakley
Renresentative of the Office of Graduate Studies

DEPARTMENT APPROVAL:

Martha Works, Chair

Department of Geography 


\begin{abstract}
An abstract of the thesis of David Graves for the Master of Science in Geography presented August 11, 2005.
\end{abstract}

Title: An Assessment of the Impacts of Climate Change on the Upper Clackamas River Basin with a Distributed Hydrologic Model

The Pacific Northwest is dependent on seasonal snowmelt for water resources that support a significant portion of its economy. Increased temperatures resulting from higher concentrations of atmospheric greenhouse gases may cause disruptions to these resources because of reductions in the annual snowpack and variations of the timing of snowmelt. This study reconstructs and applies a GIS-based distributed hydrologic model at a monthly scale to assess the effects of future climate change on runoff from the Upper Clackamas River Basin (located near Portland, Oregon). Historic flow data and snow measurements are used to calibrate and test the performance of the hydrologic model for a contemporary period (1971-2000), and the model is run for two future scenarios (2010-2039 and 2070-2099) using IS92 climate change scenarios from two global climate circulation models (Hadley and Canadian Centre for Climate) as inputs.

The results forecast that mean peak snowpack in the study area will drop dramatically ( $36 \%$ to $49 \%$ by $2010-2039$, and $83 \%$ to $88 \%$ by $2070-2099$ ), resulting in earlier runoff and diminished spring and summer flows. Increases to mean winter runoff by the $2070-2099$ period vary from moderate $(13.7 \%)$ to large $(46.4 \%)$, 
depending on the changes to precipitation forecasted by the global climate circulation models. These results are similar to those of other studies in areas dependent on snowpack for seasonal runoff, but the reductions to snowpack are more severe in this study than similar studies for the entire Columbia Basin, presumably because the elevations of much of the Upper Clackamas Basin are near the current mid-winter snow line. 
(AN ASSESSMENT OF THE IMPACTS OF CLIMATE CHANGE

ON THE UPPER CLACKAMAS RIVER BASIN

WITH A DISTRIBUTED HYDROLOGIC MODEL '

by

DAVID GRAVES

A thesis submitted in partial fulfillment of the

requirements for the degree of

\author{
MASTER OF SCIENCE \\ in \\ GEOGRAPHY
}

Portland State University

2005 


\section{TABLE OF CONTENTS}

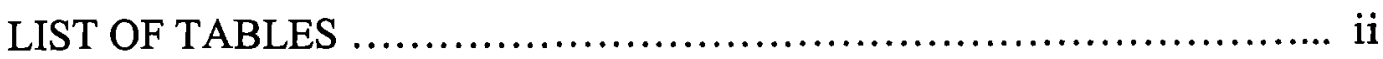

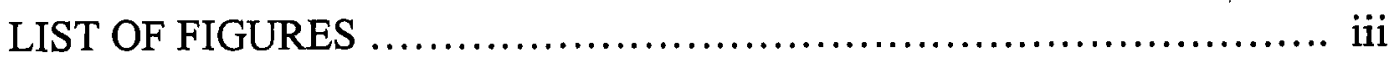

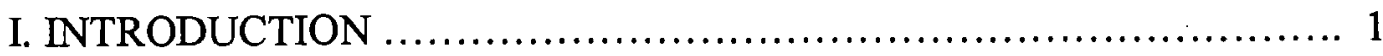

II. HYDROLOGIC PROCESSES AND MODELS $\ldots \ldots \ldots \ldots \ldots \ldots \ldots \ldots \ldots . \ldots$

Precipitation

Snow Accumulation and Melt

Soil Infiltration and Storage of Moisture

Evaporation and Transpiration

Hydrologic Models

III. STUDY AREA DESCRIPTION

Geology and Soils

Climate

Hydrology

Basin Ecology and Water Quality

Land Use

IV. DATA AND METHODS

Input Data

Assessment of Soil Infiltration and Field Capacity

Data Construction for Gridded Study

Model Structure and Implementation

V. MODEL CALIBRATION AND VALIDATION

Model Calibration

Model Validation

VI. MODEL APPLICATION FOR CLIMATE CHANGE SCENARIOS 77

VII. RESULTS AND DISCUSSION ...................................... 83 Annual Effects of Climate Change

Monthly and Seasonal Changes to Flow

Monthly and Seasonal Changes to Snowpack

Discussion

VIII. CONCLUSIONS 105

REFERENCES CITED 109 


\section{LIST OF TABLES}

TABLE

PAGE

Table 1: A review of some hydrologic models

Table 2: Mean winter precipitation and temperature and ENSO/PDO cycles 30

Table 3: Processes not simulated in hydrologic model

Table 4: Tuning parameters used for calibration

Table 5: Modifications to the structure of the original model 64

Table 6: Initial and final values of calibrated parameters

65

Table 7: Results of Sensitivity Analysis (1971-2000)

Table 8: Results of Kolmogorov-Smirnov Test for normal data distribution

Table 9: Statistical tests used for validation of model with 1986-2000 data

69

Table 10: Changes to mean monthly temperatures of the UCB from GCMs

Table 11: Annual UCB precipitation and modeled outputs of 5 climate scenarios

83

Table 12: Seasonal UCB measured and modeled flow rates

Table 13: Seasonal modeled runoff change by elevation range

Table 14: The correlation of seasonal modeled runoff change to elevation 


\section{LIST OF FIGURES}

Figure 1: Soil water capacities (Klocke and Hergert 1996) 11

Figure 2: Map of Clackamas River Basin and study area 20

Figure 3: Map of UCB geologic types $\quad 22$

Figure 4: STATSGO Map units and soil characteristics 24

Figure 5: Mean monthly temperature (1971-2000): UCB 25

Figure 6: Mean monthly precipitation (1971-2000): UCB 26

Figure 7: Average SWE (1981-2000): Clackamas Lake SNOTEL 27

Figure 8: Annual winter precipitation and ENSO/PDO cycles 29

Figure 9: Annual winter temperature and ENSO/PDO cycles 29

Figure 10: Watersheds of the UCB 31

Figure 11: Ecoregions of the UCB $\quad 34$

Figure 12: 1992 Land cover of the UCB $\quad 39$

Figure 13: Soil infiltration by map unit $\quad 42$

Figure 14: Soil curve number - UCB . . 43

Figure 15: Soil available water capacity - UCB 44

Figure 16: Wilting point of soils - UCB $\quad 45$

Figure 17: Field capacity - UCB 46

Figure 18: Structure of GIS hydrologic model $\quad 52$

Figure 19: Diagram of water management in the Oak Grove Fork watershed 54

Figure 20: Comparison of mean monthly direct runoff and indirect runoff 63

Figure 21: Monthly intensity of precipitation in the UCB 63

Figure 22: Mean monthly measured vs. modeled (initial and final) flows 66

Figure 23: Mean monthly comparison of observed and modeled flows $\quad 70$

Figure 24: Monthly comparison of observed and modeled flows 71

Figure 25: Comparison of actual and modeled SWE at Clackamas Lake SNOTEL 73

Figure 26: Comparison of actual and modeled SWE at Peavine Ridge SNOTEL 74

Figure 27: Mean Monthly Model Outputs, 1986-2000 75

Figure 28: Relative location of UCB and neighboring GCM grid cells $\quad 80$

Figure 29: UCB mean monthly modeled flows of baseline and 2020s

Figure 30: UCB mean monthly modeled flows of baseline and 2080s 85

Figure 31: Modeled flow change by UCB watershed during high flow months 87

Figure 32: Modeled flow change by UCB watershed during high flow months 88

Figure 33: Seasonal UCB flow change from baseline: Hadley 2020s scenario 90

Figure 34 Seasonal UCB flow change from baseline: CCC 2020s scenario 90

Figure 35: Seasonal UCB flow change from baseline: Hadley 2080s scenario 91

Figure 36 Seasonal UCB flow change from baseline: CCC 2080s scenario ${ }^{\circ} 91$

Figure 37: Average modeled snow water equivalent under five scenarios 94

Figure 38: Modeled distribution of snowpack with the CCC simulation 96

Figure 39: Modeled distribution of snowpack with the Hadley simulation 97 


\section{INTRODUCTION}

Seasonal snowmelt supports large portions of the urban and rural economies of the Pacific Northwest. An extensive reservoir system on the Columbia and Snake rivers stores water for flood control and seasonal fluctuations in demand, but the storage of mountain precipitation in the form of snow is essential to the functioning of ecological and economic systems that use this water. Despite a large network of dams and reservoirs, the total reservoir capacity of the Columbia Basin is only $30 \%$ of total flow and the winter snowpack is its most effective storage medium (Miles et al. 2000). Heavy winter precipitation falls as snow in the mountains and this water is slowly released when this snow melts during the spring and summer, supporting downstream uses. Hydropower facilities designed according to seasonal snowmelt cycles generate the majority of the electricity used in the burgeoning urban economies located west of the Cascades; prolific salmon runs throughout the Columbia Basin are adapted to migrate and spawn during spring and summer runoff; and agricultural hubs east of the Cascades rely primarily on snowmelt to irrigate their crops through dry summer months.

Since the industrial revolution, anthropogenic releases have increased the atmospheric concentrations of greenhouse gases, primarily carbon dioxide and methane, but also including ozone, nitrogen oxides, sulfur oxides, chlorofluorocarbons, hydrocarbons, and other elements. This increase in greenhouse gases is correlated to a warming trend that has occurred globally, including in the Pacific Northwest (Schneider 1997; IPPC 2001). Global climate circulation models forecast that this warning trend will continue during the $21^{\text {st }}$ century, although the 
magnitude of this change is somewhat uncertain, depending on several complex variables and interactions within and between the oceans and the atmosphere, as well as the societal response to this issue (IPPC 2001).

In the Pacific Northwest, increasing temperatures will likely cause disruptions to water resources because of reductions in the annual snowpack and variations of the timing of snowmelt. Even small increases in temperatures may have a significant effect on the timing of runoff, particularly in areas of moderate elevation near the current mid-winter snow line (Mote et al. 2003). Regonda et al. (2005) found that over the past 50 years, peak spring flows have been occurring earlier throughout the Western United States, and have advanced most in mountainous areas of the Pacific Northwest below 2500 meters, where winter temperatures are close to the melting point. However, Stewart et al. (2005) showed the opposite trend in the basins of the lower Willamette Valley, where spring melt actually occurred later, possibly because of the overriding effect of the Pacific Decadal Oscillation.

Recent studies of the Columbia Basin portend significant disruptions to the economy and natural systems that rely on seasonal water supplies in the Pacific Northwest under several climate change scenarios (Hamlet and Lettenmaier 2000; Miles 2000; Mote et al. 2003; Payne et al. 2004; Service 2004). Simulations of the Columbia Basin have forecast an increasing stress on water management systems and difficult tradeoffs between ecological uses (such as salmon migration) and economic uses (such as irrigation and hydropower production) under a warming climate. Past experience also supports these projections: low stream flow conditions during the 1992 water year caused an approximate loss of $\$ 273$ million for the Bonneville Power 
Administration, as well as other water shortages throughout the basin (Miles et al. 2000).

Hydrologic modeling offers an approach to simulate the effects of climate change on both large and small basins in order to better anticipate the potential impacts on local water resources. It is important to study local impacts because water is most often managed as a local resource and conditions often vary greatly between watersheds.

This study reconstructs and applies a hydrologic model to assess the effects of $21^{\text {st }}$ century climate change on runoff from the Upper Clackamas River Basin, which is located southeast of Portland, Oregon. The model is a spatially distributed approach, which considers the heterogeneous characteristics of the watershed (land cover, topography, and soils) and models key physical processes throughout the study area. This type of approach is made easier by the use of GIS technology, providing an alternative to the simpler "lumped" method, which considers the watershed as a single, homogeneous entity.

The Upper Clackamas River Basin (UCB) is a forested area that hosts a productive salmon fishery and four large hydroelectric facilities. The UCB receives large amounts of snow during the winter, but its moderate elevation means that a warming climate could change much of this snowfall to rain. A soil water balance model that was designed by Knight et al. (2001) is used at a monthly scale with $1 \mathrm{~km}$ cells to generate an estimation of the potential effects of climate change on the timing and quantity of runoff from the UCB. GIS data including climate, soils, and land cover data are used as inputs and the model is programmed from existing scientific 
literature into a database program (MS Access). Historic flow data and snow measurements are used to calibrate the performance of the hydrologic model over a contemporary period (1971-1985). Once calibrated, the model is validated for a second period (1986-2000) using goodness-of-fit statistical methods. The validated model is then run for two future scenarios (2010-2039 and 2070-2099) using projections of climate change from two global climate circulation models (Hadley and Canadian Centre for Climate) as inputs. The results are presented in statistical and graphical formats and are assessed to answer the following hypothesis and related research question:

Hypothesis

Temperature increases and precipitation changes projected by global models of increased greenhouse gas concentrations would significantly alter runoff patterns from the Upper Clackamas River Basin, causing earlier snowmelt runoff and diminished summer flows.

\section{Related Research Question}

How well does a distributed hydrologic model predict runoff from a medium-sized Pacific Northwest watershed where snowmelt is the most important contributor to runoff? 


\section{HYDROLOGIC PROCESSES AND MODELS}

A conceptual hydrologic model is designed to simulate some of the physical processes that occur within the atmosphere, landscape, and soil. Before introducing the model used in this research, it is helpful to describe the major processes that affect runoff from a watershed as well as some other applications of hydrologic models.

\section{Precipitation}

Precipitation is the principal controller of the hydrologic cycle. Its relative abundance, timing, and intensity limit the quantity and rate of runoff from a catchment. Precipitation occurs through a warm-cloud process when moisture in the atmosphere condensates and coalesces into water droplets, and two conditions exist: (1) a sufficient moisture supply; and (2) sufficient vertical motion to cause cooling of the air and collisions between droplets (Jones 1997). Air rises through natural or forced convection, and it cools until it reaches the dew point where the air is saturated. Beyond this point, condensation releases the latent heat of vaporization. In practice, condensation nuclei in the air such as clay particles are almost always part of the precipitation process. These particles act as a surface for rain to condensate around, and allow precipitation to occur before the air is supersaturated (Jones 1997).

Several methods exist to measure precipitation, from ground-based measurements like the weighing rain gauge, which measure actual receipts, to more expensive devices such as weather radar, which send active pulses of radiation and capture the energy that is deflected off of falling precipitation. No one method is perfect and multiple approaches are commonly incorporated to improve accuracy and 
for the purpose of calibration (Jones 1997). Areal precipitation may be estimated by extrapolating point measurements, but requires an estimation of the error of the measurements and a method to interpolate these points across the area. In mountainous areas, this process is difficult if insufficient measurements are available (a common problem) because precipitation can vary considerably according to altitude and topography (Dunne and Leopold 1978).

Precipitation occurs on a continuum and the runoff response of a watershed to a rainfall event depends on local conditions such as the saturation of the soil from previous rain. Flooding is also affected by the intensity of rainfall, and intense storms will usually produce greater runoff than steady rains, given the same quantity of precipitation (Dunne and Leopold 1978). The temporal scale of precipitation data is therefore a constraint; a flood event may be easy to assess with hourly precipitation data but won't be apparent in monthly reports.

\section{Snow Accumulation and Melt}

While warm-cloud processes produce rainfall droplets, a cold-cloud process may occur in the atmosphere at sub-freezing temperatures and produces ice crystals. The saturation vapor pressure over ice is slightly less than that over water, but this small difference is important because it allows ice crystals to grow quickly once formed, as they readily pull moisture out of the air (Jones 1997). Like water droplets, ice crystals also form around condensation nuclei in the air, and grow until they are heavy enough to fall. Ice crystals may melt on the way to the surface and become rainfall, or collide with each other and form snow. 
Snow may be created at any latitude, but.surface temperatures must be sufficiently low for it to reach the earth and persist on the ground. The heaviest snow accumulations are found in mountains of the mid-latitude and subpolar regions, which have low temperatures and receive relatively high amounts of precipitation (Price 1981). Snow absorbs less shortwave radiation because of its high albedo and it is an efficient emitter of longwave radiation. These two characteristics contribute to a positive feedback mechanism by which snow cover, once established, is only diminished by a substantial increase in radiation or heat (Jones 1997). Snow insulates the underlying soil, and its temperature is maintained around $0^{\circ} \mathrm{C}$ while pressure and temperature gradients contribute to its metamorphism into different forms (Price 1981).

Snowmelt is driven predominantly by the energy balance of the snowpack, but is also affected by the spatial heterogeneity of the snow, processes of crystal metamorphosis, and the development of isothermic conditions within the snowpack (Jones 1997). The initial warming of the snow causes the metamorphism of crystals into larger and denser clusters that are "ripened" for melting (Jones 1997). Melting usually occurs at the top layer of the snow and the melt water then percolates down through the pack. The flow of water out of the snowpack is dependent on the underlying soil, which may absorb and transfer the water downslope or cause overland flow to occur if the soil is saturated or impermeable.

Several field methods exist to measure snow depth and constitution, and these measurements are helpful in the validation of model results. Snowmelt is measured 
through a combination of snow gauges and ground surveys, remote sensing of snow cover and its characteristics, and downstream flow gauges. Snow may be significantly redistributed by wind in areas with little or no forest cover and towards the lee sides of ridges (Marks et al. 2001). Slope is also an important factor for the redistribution of snow, affecting avalanches as well as the incremental movement of snow downslope (Price 1981). Aspect is a very important predictor of melting, particularly in mountainous areas with complex terrain at the middle and upper latitudes. In Glacier National Park, Montana, most remaining glaciers occur on northern and eastern aspects, which receive relatively less solar radiation (Key et al. 1998). Forest cover also affects the rate of snowmelt when it blocks incoming radiation. Canopy warming may increase longwave radiation, but the net impact of forests has been found to be an overall reduction in melt rates (Semadeni-Davies 1997). The choice of a representative location for a snow gauge is thus important because snow receipts and movement are affected by the local terrain and vegetation.

\section{Soil Infiltration and Storage of Moisture}

Soil infiltration capacity is an important component of many hydrologic models. Infiltration rates vary considerably but are generally higher in thick, dry soils and during low rainfall intensities (Jones 1997). Water infiltrates the soil at a high initial rate, and as the soil becomes saturated, infiltration decreases and direct runoff (overland flow) increases. Soil structure and texture are probably the most important soil characteristic influencing the rate of infiltration (Gerrard 2000). Sands and gravels have the highest infiltration rates and soils with blocky or prismatic structures 
allow greater infiltration (Jones 1997; Gerrard 2000). Soil pH also affects infiltration; neutral or moderately alkaline soils often have crumb structures that increase infiltration and their higher nutrient content attracts organisms such as earthworms, which create pores that water enters. Relief is another important factor; steep slopes have lower infiltration capacities and convex slopes have higher rates of infiltration than concave slopes (Jones 1997).

Infiltration rates are also affected by vegetation and seasonal influences. Plants intercept precipitation in their leaves, increasing evaporation and decreasing water that is available for soil infiltration. However, vegetation generally has a net impact of increasing infiltration, because water that reaches a vegetated surface may easily enter the soil through cracks around stems, trunks, and roots (Jones 1997). Vegetation also adds more organic content to the soil, which increases infiltration rates by providing matter that binds soil together in clumps, and by attracting soil fauna that create pore spaces such as earthworms (Dunne and Leopold 1978). Seasonally, soil infiltration rates are generally thought to be higher during the summer when soils are drier, but Johnson and Beschta (1981) found it be significantly higher (50\%) during the late fall than the summer in forested experimental sites in the central and southern Oregon Cascades. The cause for this difference is unknown, although one possibility cited in this study is a hypothetical non-wettable surface condition of the Cascade forest soils that is caused by high soil temperatures during the summer.

Infiltrated water enters the soil and is traditionally described as being stored in two different zones. The zone of aeration contains pores normally filled with air, which provide a capacity for moisture storage. Soil moisture refers to the water 
content of this zone. When the zone of aeration is saturated, water then escapes through indirect runoff (throughflow) to contribute downslope to the stream network. Below the zone of aeration, a zone of saturation exists within the bedrock or parent material that is also described as the permanent water table (Jones 1997). This is a simplification, however, and in reality, the two zones interact with each other. Surface soils are permanently saturated in some areas, creating anaerobic conditions and hydric soil types near the surface. Surface water also enters the zone of saturation over time, and water from the zone of saturation contributes effluent seepage into the basin as base flow (Jones 1997).

Simple soil water models commonly focus on the zone of aeration to determine direct and indirect runoff, without attempting to simulate fluctuations of the zone of saturation. Several processes and terms describe the capacity of the zone of aeration to store water. When precipitation or melting snow enter the soil, a portion of it is stored in the pore spaces and the rest is drained by gravity. Smaller pores retain water longer because capillary forces are stronger in these pores (Dunne and Leopold 1978). The field capacity of the soil is the maximum water content that a soil can hold after the soil has been saturated and then freely drained by gravity, and depends on the volume and size of the pores in the soil (Klocke and Hergert 1996).

When a soil reaches field capacity, surplus moisture easily escapes through evaporation, transpiration, or runoff (Gerrard 2000). Because field capacity refers to the moisture-holding capacity of the water, it includes both hygroscopic water and water that is available to vegetation. Hygroscopic water is soil moisture that is not available to plants because it is held in thin films around soil particles, mostly those of 
clay minerals (Gerrard 2000). The wilting point is the tension at which plants cannot remove this hygroscopic water and will permanently wilt. It is commonly described as 15 bars of pressure but will vary somewhat based on plant type (Jones 1997;

Gerrard 2000). The available water capacity of the soil is the amount of water that a soil may hold that is available to plants and is therefore the difference between the wilting point and the field capacity of the soil (see Figure 1). It is usually recorded as a proportion (moisture (in)/ soil depth (in)) but may also be calculated as an absolute volume in a soil. (NRCS 1997).

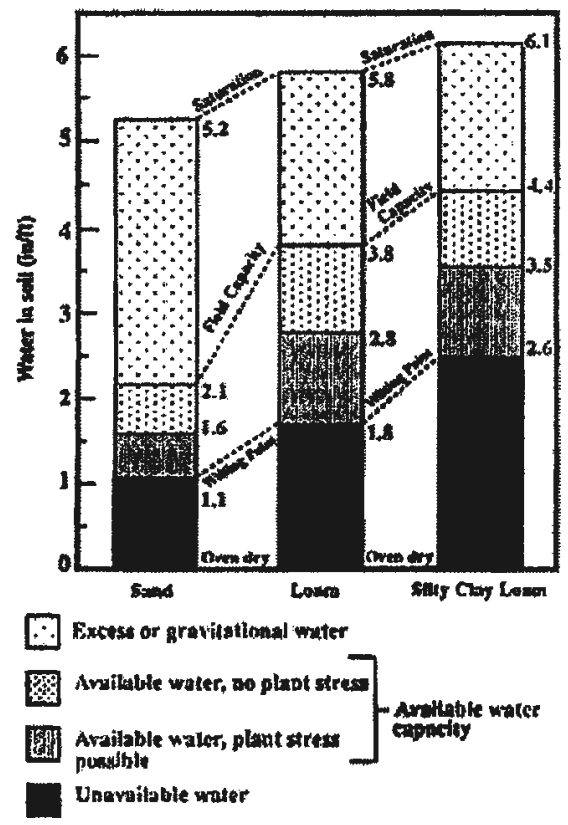

Figure 1: Soil water capacities (Klocke and Hergert 1996)

\section{Evaporation and Transpiration}

In most areas, a large proportion of precipitation doesn't leave a watershed as runoff, but instead escapes to the atmosphere through evaporation or transpiration by plants. A hydrologic model should include these two important processes, although 
they are often considered together as evapotranspiration because transpiration is notoriously difficult to measure (Jones 1997).

Evaporation refers to the conversion of water from a liquid to a gas and the transfer of that gas to the atmosphere. Energy is needed for this exchange, and it most often is derived from sunlight. Latitude, season, time of day, and cloud cover are therefore important factors that determine the rate of evaporation (Dunne and Leopold 1978). Globally, mountainous areas produce a disproportionately large share of runoff in part because they experience lower rates of evaporation (Viviroli and Weingartner 2004). Evaporation is often measured as the loss of water from small pans placed in the field. A pan is small and receives larger relative amounts of energy through its base and sides, so water evaporates from it at a greater rate than it would from a natural body of water. To account for this, a pan coefficient is used to approximate the ratio between actual evaporation and pan evaporation. This coefficient will vary based on local conditions, and if it has not been empirically determined, then an average annual value of .70 to .75 is often assumed (Dunne and Leopold 1978).

Transpiration refers to the perspiration of moisture from plants to the atmosphere, primarily through stomata and cuticles in plant leaves. Stomata open as a result of osmotic pressure changes that are related to air temperature: at higher air temperatures, transpiration will occur at a greater rate. Transpiration is used by plants to moderate their temperature and to provide other basic functions related to photosynthesis and respiration.

Several methods have been developed to estimate and predict evapotranspiration $(E T)$. Fundamentally, $E T=$ precipitation - runoff $+/$ - storage. ET 
is constrained, however, by the amount of moisture that is readily available in soil and plants. Potential ET (the amount of ET that would occur with an unlimited supply of moisture) and actual ET (the proportion of potential ET that occurs given available moisture) are generally calculated with separate equations. Temperature indice equations determine potential ET based primarily on the air temperature, while mass transfer equations determine potential ET based on the vapor saturation deficit of the atmosphere. Some or all of these factors that influence Potential ET may be used in monthly calculations: (1) monthly fraction of annual hours of daylight; (2) vegetative cover or crop type; (3) average air temperature; (4) average humidity; (5) average wind speed; (6) soil cover/albedo (7) canopy cover (Dunne and Leopold 1978; Jones 1997). Canopy cover can greatly influence evaporation, because precipitation that is intercepted by a dense canopy is more likely to evaporate than precipitation that falls directly to the surface where it may infiltrate the soil or become runoff

Actual ET depends on the amount of moisture readily available for evaporation; when a soil is flooded above its field capacity to store water then the excess moisture may evaporate readily. If there is less moisture available in the soil, then it can be expected that actual ET will be proportionally less than potential ET.

\section{Hydrologic Models}

Hydrologic modeling assists water managers in planning for both long-term and short-term disruptions to supply and dependent resources, including estimations of the potential impacts of climate change. Deterministic hydrologic models are designed to approximate the physical processes that generate runoff. As described above, these 
processes are complex and occur across different spatial and temporal scales. Models should be designed to account for these processes or use empirical measurements to incorporate their effects.

Deterministic models fall into three categories based on their attention to physical processes: empirical (purely statistical models with no consideration of physical processes), physical (models that attempt to recreate the complex physical processes governing runoff), and conceptual (a compromise between physical and empirical models) (Jones 1997). These models may also be categorized based on their approach to spatial variability. Lumped models assume homogenous conditions over a basin. Distributed models simulate spatial variation throughout a basin and may incorporate advances in Geographic Information Systems (GIS) technology. Distributed approaches are better suited for use in heterogeneous landscapes that are typical in mountainous areas, because differences in physiographic and hydroclimatic conditions can be better represented (Semadeni-Davies, 1997; Knight et al., 2001).

Spatial and temporal scales are important components of model design. Hydrologic models describe processes that occur on a fine spatial scale, but they must often be designed at a coarse scale when basin size, available data, or processing constraints limit the detail of the spatial resolution. Temporal scale may also be limited by the available data and the objectives of the model (Semadeni-Davies 1997).

An examination of hydrologic models illustrates the varied approaches that have been used to simulate hydrologic processes in different basins. The examples described in Table 1 are not a comprehensive assessment of all of the many modeling 
approaches that are used, but instead are a few selected samples of different studies that have been conducted to assess climate change. 
Table 1: A review of some hydrologic models used to assess the impacts of climate change

\begin{tabular}{|c|c|c|c|c|}
\hline Name & Description & Study Area & Results & Reference \\
\hline $\begin{array}{l}\text { Modified } \\
\text { version } \\
\text { of } \\
\text { Snowmelt } \\
\text { Runoff } \\
\text { Model } \\
\text { (SRM- } \\
\text { ETH) }\end{array}$ & $\begin{array}{l}\text { Model lumps the physical terrain into five } \\
\text { elevation bands to represent the basin and } \\
\text { uses snow cover from satellites as the primary } \\
\text { input. It evaluates runoff for past conditions } \\
\text { using empirical measurements of flow from } \\
\text { the watershed and runoff coefficients are } \\
\text { developed for rain and snow based on this } \\
\text { data and precipitation and temperature } \\
\text { records. }\end{array}$ & $\begin{array}{l}\text { Upper } \\
\text { Rhine- } \\
\text { Felsberg } \\
\text { Basin ( } 3250 \\
\mathrm{~km}^{2} \text { in the } \\
\text { eastern } \\
\text { Swiss Alps }\end{array}$ & $\begin{array}{l}\text { Future climate scenarios (from } 2030 \text { and } 2100 \text { ) were } \\
\text { compared with a normalized year to anticipate future } \\
\text { changes in runoff. The authors found an expected } \\
\text { decrease in snow accumulation and a disruption to the } \\
\text { seasonal flow from the basin }\end{array}$ & $\begin{array}{l}\text { Seidel et al. } \\
(1998)\end{array}$ \\
\hline $\begin{array}{l}\text { Degree- } \\
\text { Day } \\
\text { Snowmelt } \\
\text { Model }\end{array}$ & $\begin{array}{l}\text { Degree-day approach predicts snow } \\
\text { accumulation and melt. Semi-distributed } \\
\text { model divides the study areas into 200-meter } \\
\text { elevation bands, which are then further } \\
\text { subdivided by land cover information to form } \\
\text { discrete areas with assumed uniform } \\
\text { characteristics. Monthly climate data are } \\
\text { used to generate pseudo-daily values, } \\
\text { eliminating extreme events that might bias the } \\
\text { results. }\end{array}$ & $\begin{array}{l}\text { Three } \\
\text { watersheds } \\
\text { in Northern } \\
\text { Europe: } \\
\text { Valuoja } \\
\left(3.94 \mathrm{~km}^{2}\right) \text { in } \\
\text { Estonia, and } \\
\text { Kultsjon } \\
\left(1109 \mathrm{~km}^{2}\right) \\
\text { and } \\
\text { Gimdalsbyn } \\
\left(2164 \mathrm{~km}^{2}\right) \\
\text { in Sweden }\end{array}$ & $\begin{array}{l}\text { The model was run for a different series of historical } \\
\text { years (1940's-1990) in each study area and tested } \\
\text { statistically with historical stream flow and snow gauge } \\
\text { records. The temporal accumulation and melt of snow } \\
\text { was predicted fairly accurately in all three basins ( } r= \\
0.87,0.85,0.55 \text { ), although the snow season peak tended } \\
\text { to be calculated somewhat later than the actual date. } \\
\text { Modeling in the smallest watershed, the Valuoja, } \\
\text { provided the most accurate results. In the Kultsjon } \\
\text { basin, the seasonal pattern was well represented but } \\
\text { estimates for overall runoff were low and the model } \\
\text { wasn't able to predict Snow Water Equivalence (SWE) } \\
\text { above the tree line because of snowpack redistribution. } \\
\text { In the Gimdalsbyn, the largest basin, annual discharge } \\
\text { estimates were accurate, but the timing of the melt was } \\
\text { not correct. }\end{array}$ & $\begin{array}{l}\text { Semadeni- } \\
\text { Davies } \\
\text { (1997) }\end{array}$ \\
\hline $\begin{array}{l}\text { Soil- } \\
\text { based } \\
\text { model } \\
\text { (SWAT) }\end{array}$ & $\begin{array}{l}\text { A coupled variable analysis shows the } \\
\text { significance of five different variables } \\
\text { (temperature, precipitation, } \mathrm{CO}_{2} \text {, radiation, } \\
\text { and humidity) on water yield. }\end{array}$ & $\begin{array}{l}\text { Upper Wind } \\
\text { River Basin } \\
\text { of Wyoming }\end{array}$ & $\begin{array}{l}\text { Assessed the effects of climate change. Annual water } \\
\text { yield is most affected by precipitation and that } \\
\text { temperature is the most influential variable for the } \\
\text { timing of streamflow, while the other variables affect } \\
\text { water yield to a lesser extent. These variables are also } \\
\text { found to offset each other in some cases (for example, } \\
\text { increased temperature offset increased precipitation). }\end{array}$ & $\begin{array}{l}\text { Stonefelt et } \\
\text { al. (2000) }\end{array}$ \\
\hline
\end{tabular}




\begin{tabular}{|c|c|c|c|c|}
\hline $\begin{array}{l}\text { Struma } \\
\text { River } \\
\text { Model }\end{array}$ & $\begin{array}{l}\text { Distributed, soil water-balance model } \\
\text { incorporates GIS. Physiographic, land-cover, } \\
\text { and hydro-climatic data are collected to } \\
\text { conceptually model monthly and annual } \\
\text { runoff under variable climate conditions. }\end{array}$ & $\begin{array}{l}\text { Struma } \\
\text { River Basin } \\
\text { of Bulgaria }\end{array}$ & $\begin{array}{l}\text { The model was run over the } 1961 \text { to } 1990 \text { period, } \\
\text { comparing monthly simulated flow to mean observed } \\
\text { flow. The model slightly underestimated winter flow } \\
\text { and slightly overestimated April and summer flows. The } \\
\text { resolution of the model (2 km) may not have been fine } \\
\text { enough to capture many local basin variations. } \\
\text { Nevertheless, the authors found the model to perform } \\
\text { "reasonably well" in estimating contemporary climate } \\
\text { and runoff conditions. It was subsequently employed to } \\
\text { evaluate the effects of future climate change scenarios } \\
\text { in the same basin. The model predicted that snowmelt } \\
\text { will occur earlier, causing increased spring runoff but } \\
\text { diminished summer runoff, with no significant change in } \\
\text { annual flow. }\end{array}$ & $\begin{array}{l}\text { Knight et } \\
\text { al. (200I), } \\
\text { Chang et } \\
\text { al. (2002) }\end{array}$ \\
\hline $\begin{array}{l}\text { VIC } \\
\text { Hydrolog } \\
\text { y Model } \\
\text { and } \\
\text { ColSim } \\
\text { Reservoir } \\
\text { Model }\end{array}$ & $\begin{array}{l}\text { Integrated approach that considers physical } \\
\text { and anthropogenic factors together. The VIC } \\
\text { Hydrology Model was run with long-term } \\
\text { monthly mean precipitation and temperature } \\
\text { statistics at a } 1 / 8 \text { degree scale. It was } \\
\text { successfully tested for the } 1961-1997 \text { period } \\
\text { and then run with future projections from } \\
\text { global climate models (Hadley Centre and the } \\
\text { Max Planck Institute) for inferred conditions } \\
\text { during } 2025,2045, \text { and } 2095 \text {. The runoff } \\
\text { results from this model were integrated with } \\
\text { the ColSim Reservoir Model, which simulates } \\
\text { the major characteristics of the Columbia } \\
\text { River water resources system including the } \\
\text { major dams and reservoirs. This simulation } \\
\text { accounts for hydropower generation, } \\
\text { reservoir storage, flow targets for fisheries, } \\
\text { agricultural withdrawals, and recreation uses. } \\
\text { The integration of both models provides an } \\
\text { assessment of possible reductions in water } \\
\text { resources and their effect on water resources. }\end{array}$ & $\begin{array}{l}\text { Columbia } \\
\text { River Basin }\end{array}$ & $\begin{array}{l}\text { The results included a decrease in snowpack } \\
\text { accumulation because of warmer winter temperatures } \\
\text { and higher volumes of precipitation. This reduction is } \\
\text { exemplified by the March } 1 \text { SWE, which was projected } \\
\text { to be } 75 \% \text { to } 85 \% \text { of normal for the } 2025 \text { base year, and } \\
55 \text { to } 65 \% \text { of normal for the } 2045 \text { base year. This } \\
\text { reduction in snowpack and increase in temperatures is } \\
\text { projected to lead to earlier spring melt and a greater } \\
\text { frequency of drought conditions during the summer } \\
\text { months. The authors found that adaptation of the water } \\
\text { resource system to these changes by } 2025 \text { would be } \\
\text { difficult. The results are most dramatic for the } 2095 \\
\text { assessment, which show a radical transformation of the } \\
\text { Columbia system from a snowmelt dominated to a } \\
\text { transient snowmelt system. }\end{array}$ & $\begin{array}{l}\text { Hamlet and } \\
\text { Lettenmaie } \\
r(2000)\end{array}$ \\
\hline
\end{tabular}


The studies described in Table 1 illustrate some of the choices that are made when designing models to investigate the hydrologic impacts of climate change. For example, models that are designed for mountainous areas must carefully simulate snow accumulation and melt, while models designed for lowland areas may not be affected greatly by these processes but may be more sensitive to effects from land use practices. In general, these simulations show that in areas where snow is important, warmer temperatures will likely cause earlier spring runoff and may also reduce the quantity of overall runoff. Precipitation is a very important factor, however, and while it may be expected to increase globally through increased evaporation, changes to precipitation may vary. widely at the local scale. 


\section{STUDY AREA DESCRIPTION}

The Clackamas River Basin is a medium-sized watershed $\left(2,430 \mathrm{~km}^{2}\right)$, originating at the crest of the Cascade Mountains and flowing downstream through a forested valley and rural and urban sections to its confluence with the Willamette River, southeast of Portland (Figure 2). This study considers the upper part of the basin $\left(1,260 \mathrm{~km}^{2}\right)$, located above a series of managed reservoirs. Most $(90 \%)$ of this portion of the basin is forested and at moderate elevations (335 to 2,197 meters) (U.S. Geological Survey 1999). While this area currently generates a high proportion of its runoff from seasonal snowmelt, the intermediate elevation profile means that snow accumulation may be vulnerable to temperature increases. A previous assessment of the impacts of climate change in the Columbia Basin shows that "large reductions in flow are likely in smaller river basins with a relatively large portion of their catchments near the current mid winter snow line," because incremental warming there may cause less snow fall to occur (Mote et al. 2003). To date, no known study has examined the potential effects of climate change on the water resources of the Clackamas River Basin. 


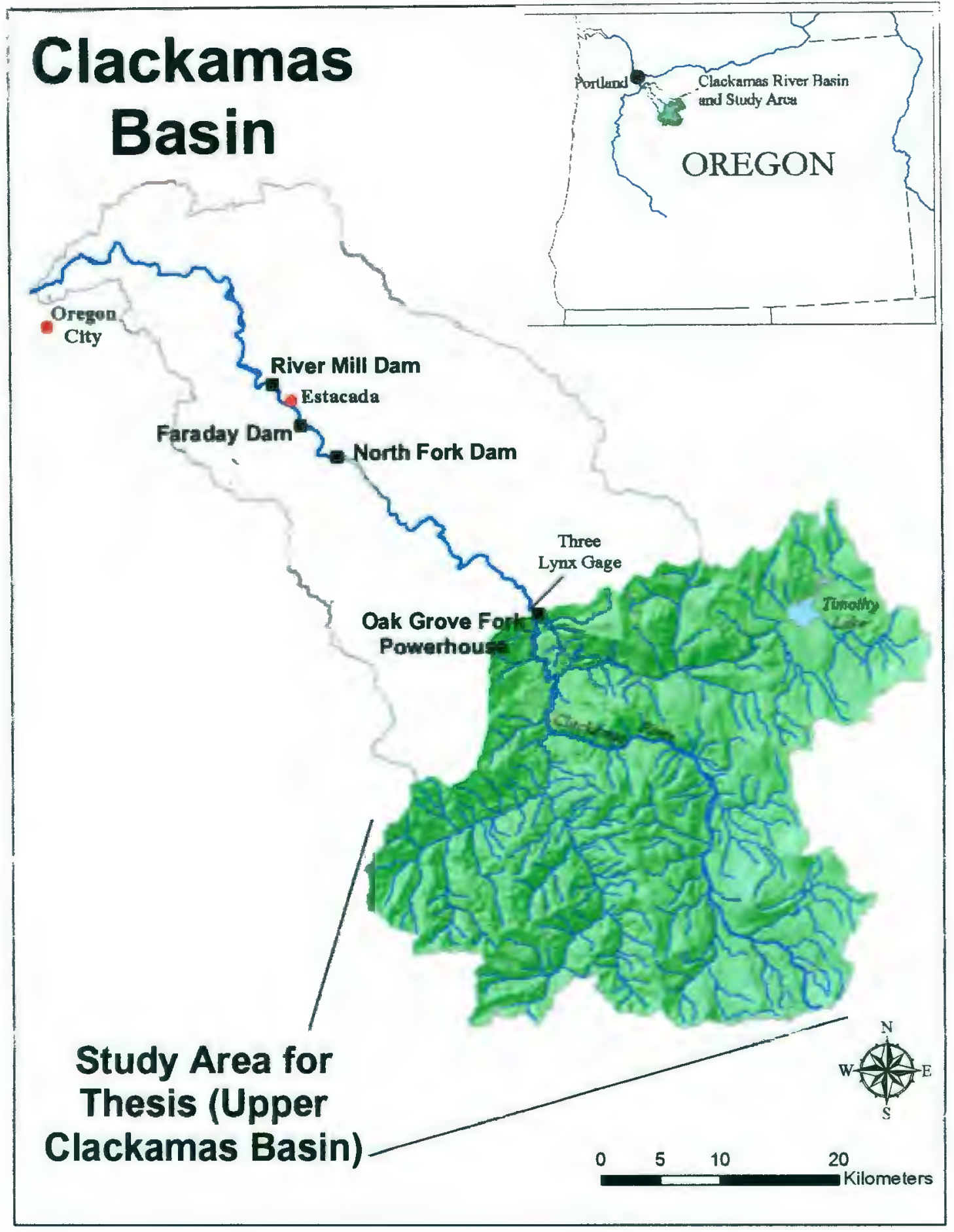

Figure 2: Map of Clackamas River Basin and study area 


\section{Geology and Soils}

The UCB is situated on the western flanks of the Cascade Mountains Range, and processes that occur in these mountains mainly determine its geology and soils. The Cascade Mountains are formed by geologic uplift that occurs along the subduction zone between the Pacific and North American Plates. As these plates converge, magma is forced upwards through openings in the surface, and it then cools and solidifies. This igneous material is weathered through both chemical and physical processes, and colluvial and alluvial processes move it downslope. Violent eruptions may also disperse ash over wide areas. Volcanic rocks and ash are therefore the major parent materials for most soils found in the watersheds that drain the Cascade Mountains

The Cascade Mountains consist of active volcanoes that are located along the Cascade Crest to the east (the High Cascades), and older, inactive mountains that are situated to the west (the Western Cascades). The UCB includes portions of both the High Cascades (in its eastern and northern area) and the Western Cascades (in its western and southern area) as shown in Figure 3 (Tague and Grant 2004). The Western Cascades are steep and deeply incised because of the considerable erosion that has occurred since their formation, while the High Cascades form a broad volcanic platform with a lower relief (Ingebritsen et al. 1992; Tague and Grant 2004). The last major period of glaciation in the Cascades (the Fraser Glaciation) ended about 10,000 years ago, and the retreating glaciers scoured the landscape, shaping the valleys and ridges of the UCB (Sherrod et al, 1996). 


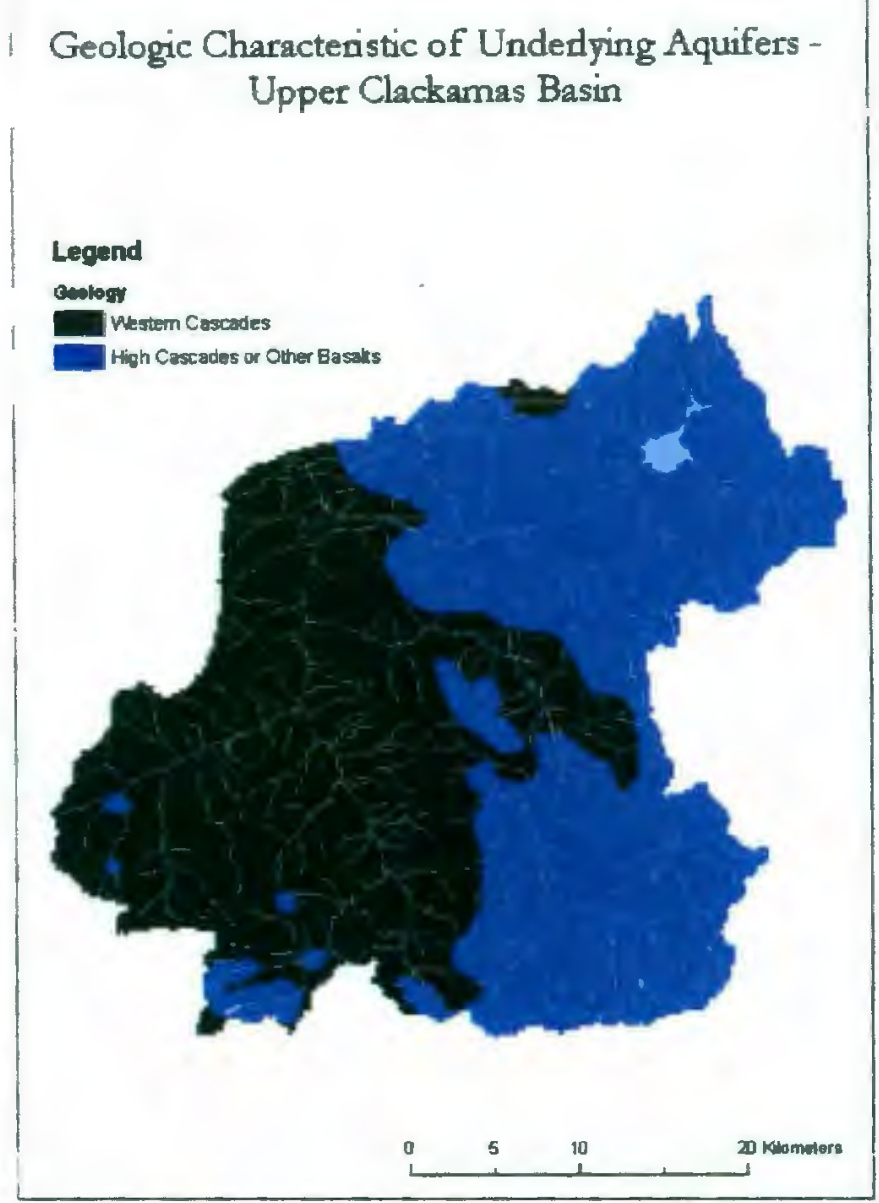

Figure 3: Map of UCB geologic types (recreated from Tague and Grant 2004)

While the upper parts of the basin are built mostly of material ejected and eroded from the Cascades, the lower Clackamas valley consists of large quantities of deposited basalts. Large inland volcanic eruptions centered around 15 million years ago produced lava flows that inundated the Columbia River and the surrounding valleys. These lava flows cooled, leaving thick layers of rock that underlie much of the Columbia Basin. Anderson (1978) examined the extent and origin of these Columbia River Basalts in the Clackamas River Basin by collecting stratigraphic samples and analyzing their constitution and geochemical properties. While cross- 
sections of the valley walls in the lower Clackamas are stacked with these basalts, Anderson found that they also extend into the upper basin, including partially up the Oak Grove Fork and the upper mainstem Clackamas Rivers.

Lithologic discontinuities (distinct breaks in the soil profile that indicate changes in parent material) are noted in both the foothills and mountains of western Oregon (Whittig et al. 1956; Parsons 1978; Glasmann and Kling 1980). Ridgetops and active slopes of greater than 45 degrees tend to have thin and poorly developed soils, while major river valleys show greater soil development, valley fill, and alluvial fans, especially below unstable south and west facing slopes (Parsons 1978). Loessal deposits from the historic release of glacial meltwater from Lake Missoula (the Willamette Silts) are common in the lower valleys but not in higher elevation areas such as the UCB (Glenn 1965; Glassman and Kling 1980; Gerig 1985).

The Natural Resource Conservation Service (NRCS) has created a hierarchical system of soil survey information for the U.S. The STATSGO database is derived from NRCS 1:250,000-scale soil maps, and is the most detailed soil data source for the UCB. The STATSGO database delineates the UCB into five map units and contains considerable information about each unit (see Figure 4). In general, the soils of the UCB are Inceptisols (generally young or underdeveloped soils) in the river valleys, and Andisols (soils formed from a volcanic parent material) and Spodosols (highly leached, acidic soils characterized by a subsurface accumulation of humus) in the higher-elevation areas (NRCS 1997; Gerrard 2000).

Most UCB soils are formed from a colluvium consisting of andesites, basalt, volcanic ash, or weathered basic igneous rock. The soil series data show most of these 
soils to be moderately deep to deep and well drained. However, map unit OR144, which is found on an undulating plateau located around the headwaters of the basin, is distinctively different. The soils there are situated on moraines and classified as being very deep and being primarily formed from a parent material of ash and glacial till.

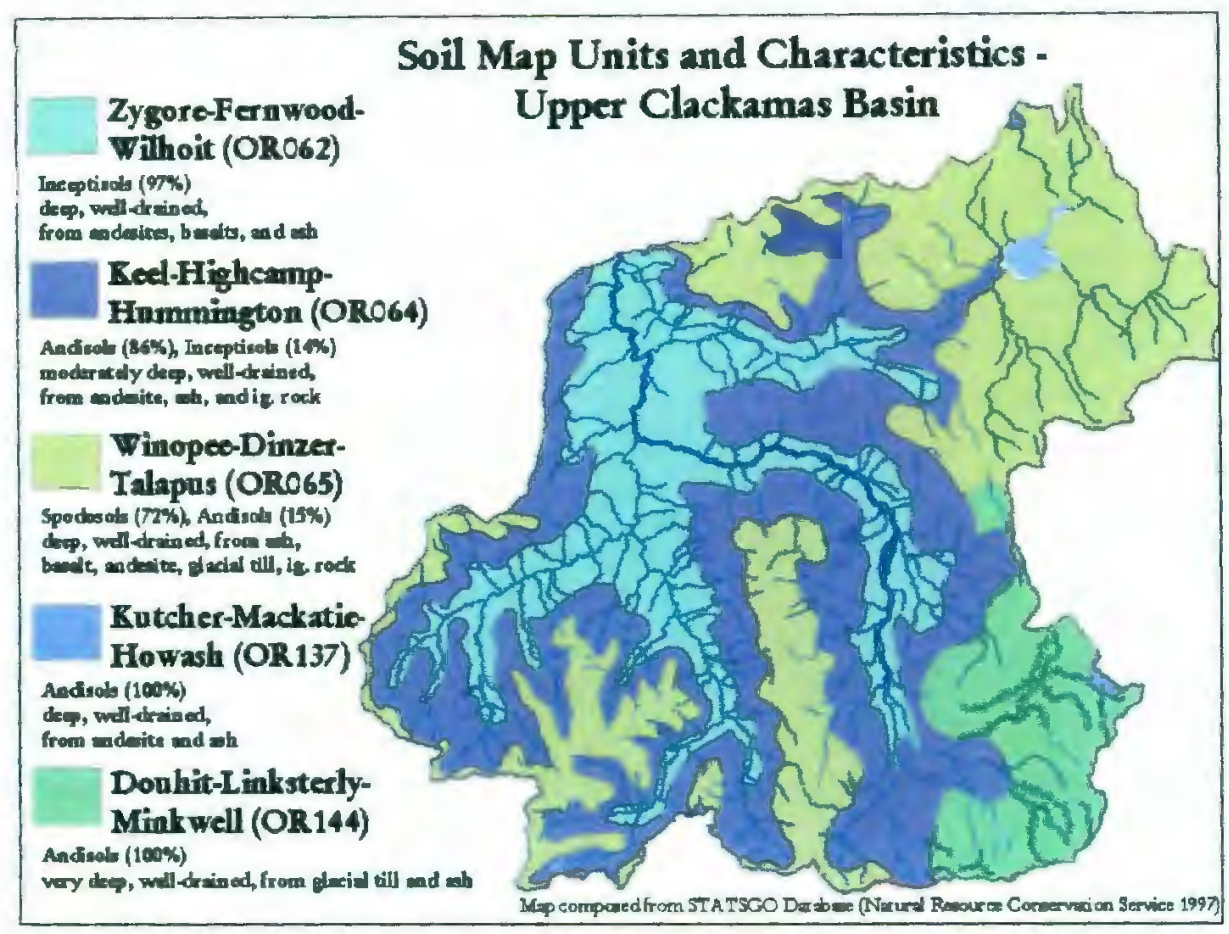

Figure 4: STATSGO map units and soil characteristics (Data from Natural Resource Conservation Service 1997)

\section{Climate}

The climate of a location is determined by several factors, including latitude, continentality, altitude, and terrain. At the latitude of the UCB (around $45^{\text {th }}$ parallel), insolation is high during the summer and low during the winter, producing distinct seasonal fluctuations in temperature. Proximity to the Pacific Ocean $(\sim 150 \mathrm{~km})$ moderates these fluctuations somewhat because of the high specific heat of the water 
in the ocean; water heats and cools slowly, curbing the extreme temperatures that occur over land. An additional moderating factor is the barrier influence of the Cascade Mountains; this range protects the west side of Oregon during the winter from the extreme lows in temperature that occur over continental areas (Dart and Johnson 1981). Average monthly temperatures fall within a moderate annual range, but winter temperatures are sufficiently low enough to produce snow (see Figure 5).

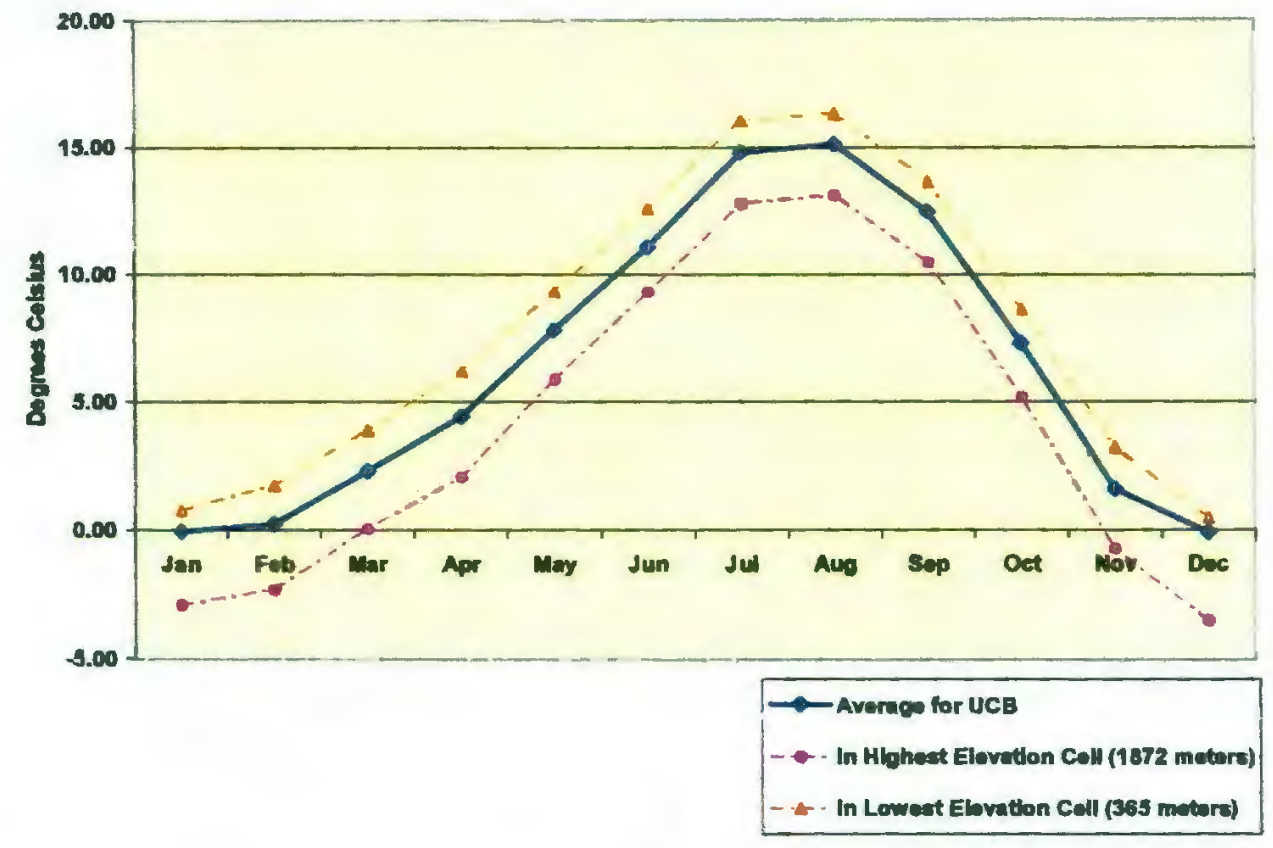

Figure 5: Mean monthly temperature (1971-2000): UCB average and highest and lowest areas) (data from PRISM Model, Spatial Climate Analysis Service 2004)

Most precipitation to the UCB is delivered by frontal systems from the Pacific Ocean between October and May. The Cascade Mountains serve as a barrier to these westerly systems; as air is forced to rise, it cools, its relative hurnidity increases, and moisture readily condenses as rain or snow. This orographic effect soaks large amounts of precipitation out of frontal systems before they are able to pass 
to eastern Oregon. Precipitation intensifies during the early winter, and west of the Cascades the wettest month (December) is nearly ten times as wet as the driest month (July) (Mote et al. 2003). Mean monthly precipitation data (Figure 6) confirms this trend in the UCB.

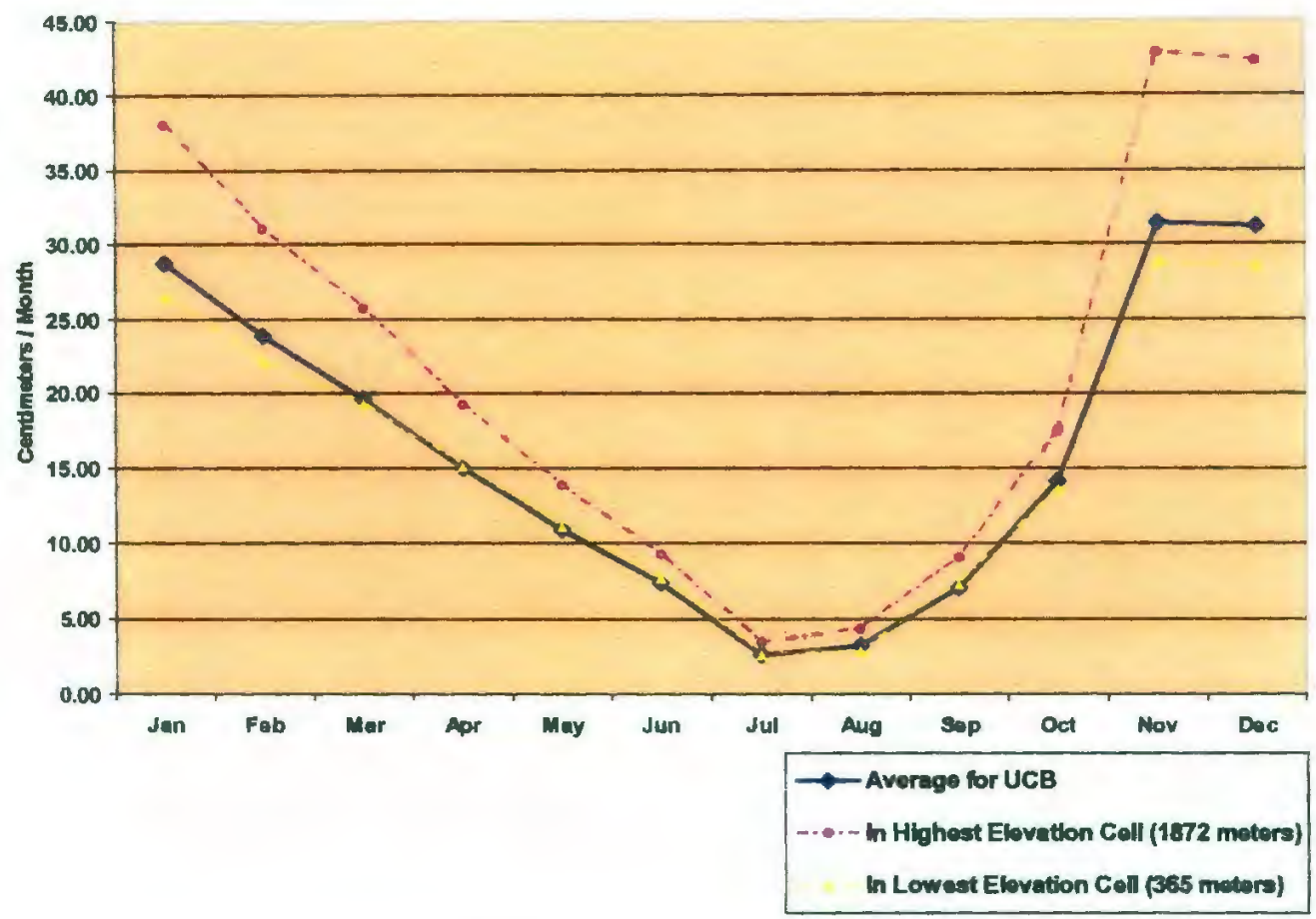

Figure 6: Mean monthly precipitation (1971-2000): UCB average and highest and lowest areas) (data from PRISM Model, Spatial Climate Analysis Service 2004)

The elevations of most areas of the UCB are lower than the nearby slopes of Mt. Hood and Mt. Jefferson, but are still high enough to generate substantial amounts of snow in most years. As air is forced to rise by the terrain it cools according to the environmental lapse rate (approximately 1-2 $\mathrm{C}$ per 300 meters) (Price 1981). This rate varies according to local conditions, including temperature inversions, cloud cover, and aspect, but is consistent enough to mean that when the Willamette Valley is being soaked by a cool winter rain, the west slopes of the Cascades will usually 
receive snow. Because the lower valleys of the UCB are nearly 1,000 meters below the peaks, this lapse rate also means that during portions of the year (generally, the late fall and early spring), the valleys of the UCB will receive rain while the upland areas get snow. Figure 7 shows a graph of average monthly snow cover at a SNOTEL site located at an elevation $(1037 \mathrm{~m})$ close to the mean elevation of the study area (1062 m). From 1981 to 2000 , the average snowpack there peaked around the beginning of March and fell quickly during the early spring, although this pattern varied considerably from year to year.

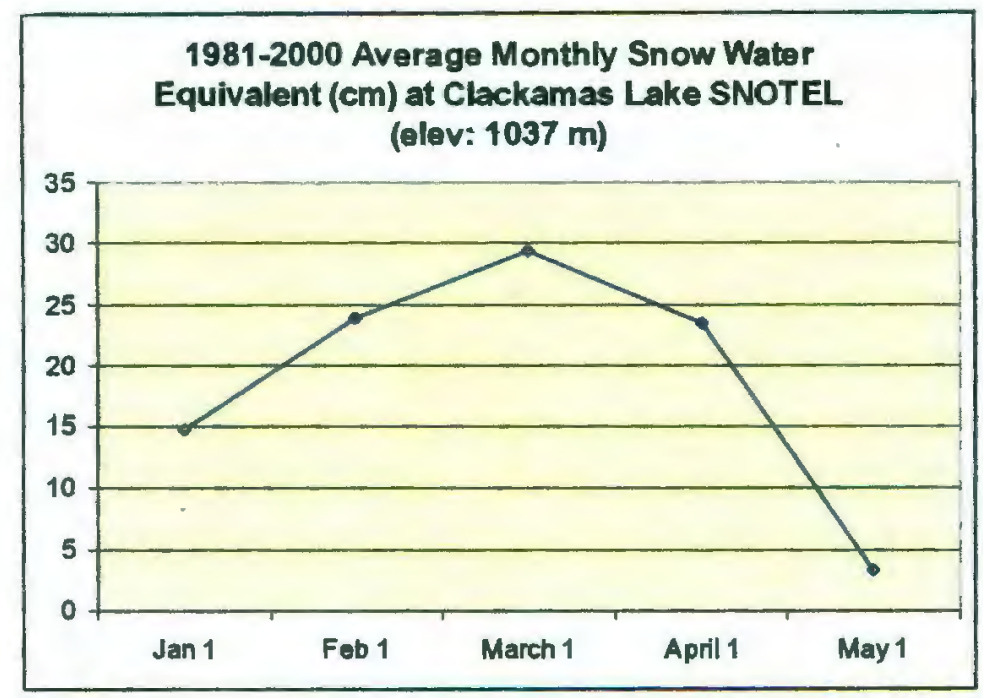

Figure 7: Average SWE (1981-2000): Clackamas Lake SNOTEL (data from Natural Resource Conservation Service 2004)

In the Pacific Northwest, conditions in the Pacific Ocean are the major determinant of year-to-year variability and climate cycles such as the El Nino Southern Oscillation (ENSO) and the Pacific Decadal Oscillation (PDO). The great amount of solar energy received in the tropical Pacific Ocean readily evaporates water and produces wind, initiating weather patterns that drive currents and systems throughout the Pacific region. In El Nino years, the eastern Pacific Ocean warms 
disproportionately and disrupts the normal weather pattern. During these events the Pacific Northwest may experience long periods of sunny and mild winter weather as storm systems are diverted north or south. During La Nina years, opposite conditions exist and the Pacific Northwest may be heavily inundated with winter storms.

On a longer time scale, climate in the Pacific Northwest varies according to the PDO. During recent times, temperatures in the central Pacific Ocean have varied by about $0.5^{\circ \circ} \mathrm{C}$ every 20 to 30 years. The PDO is said to be in a positive or "high" state when the temperatures of the Central Pacific Ocean are colder than average, and in a negative or "low" state when they are warmer than average (Collier and Webb 2002). When the PDO is in a positive state, the Aleutian Low (a frequent low pressure system south of Alaska) is strengthened, and it deflects much of the weather that would normally affect the Pacific Northwest to the south. The PDO was generally positive between 1947 and 1977, and was mostly negative after 1977. The PDO may have switched during the late 1990's, but this is not yet certain.

Snowmelt and runoff in Oregon are affected by both the ENSO and PDO cycles and the overall variability in annual water supply has been shown to be approximately 5-20\% (Beebee and Manga 2004). Figures 8-9 and Table 2 show the relationship between ENSO and PDO to winter (December to March) precipitation and temperature in the UCB based on PRISM climate data. These data confirm that in the UCB, E1 Nino years produce higher winter temperatures and lower winter precipitation, while La Nina produce the opposite effects. They also confirm similar trends for the PDO, but only a portion of the positive phase (1971-1977) is represented in the study period. 
UCB Winter Precipitation (Dec-Mar): Relationship to ENSO and PDO Cycles

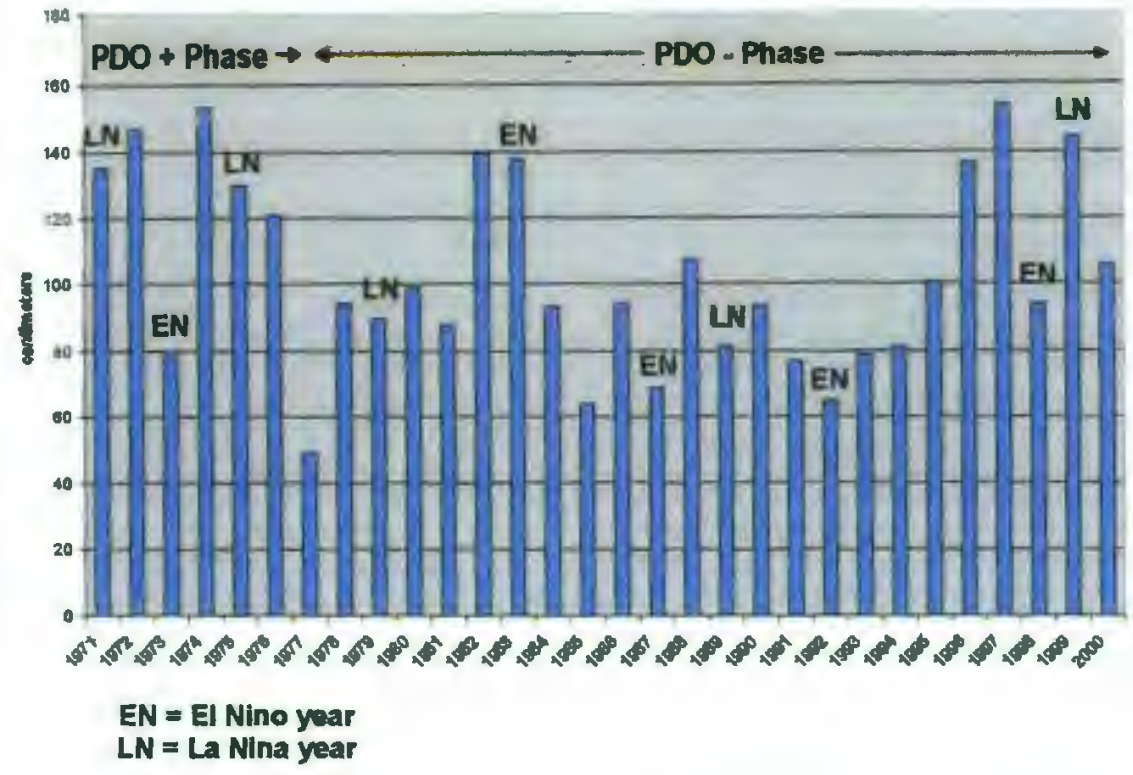

Figure 8: Annual winter precipitation and ENSO/PDO cycles (data from Natural Resource Conservation Service 2004)

UCB Winter Temperature (Dec-Mar): Relationship to ENSO and PDO Cycles

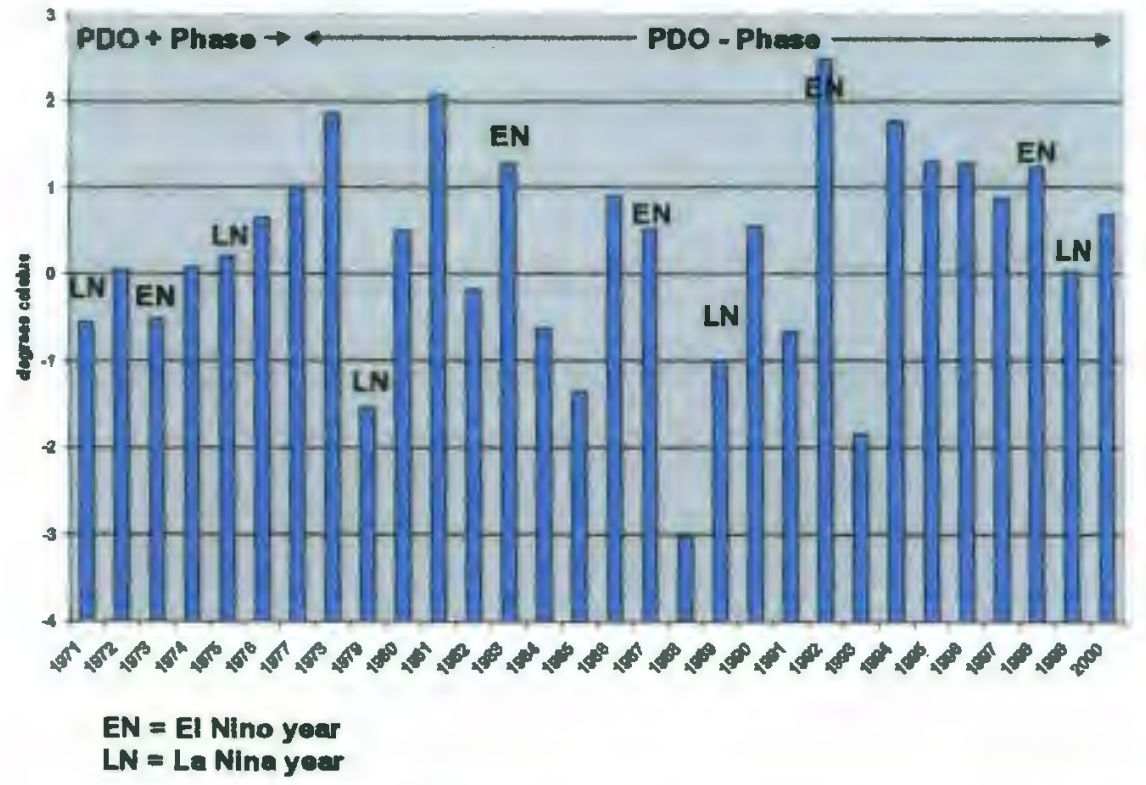

Figure 9: Annual winter temperature and ENSO/PDO cycles (data from Natural Resource Conservation Service 2004) 
Table 2: Mean winter precipitation and temperature and ENSO/PDO cycles (data from Natural Resource Conservation Service 2004)

\begin{tabular}{|l|l|l|}
\hline $\begin{array}{l}\text { ENSO Cycle } \\
(1971-2000):\end{array}$ & $\begin{array}{l}\text { Average Winter } \\
\text { (Dec-Mar) } \\
\text { Temperature }\left({ }^{\circ} \mathrm{C}\right)\end{array}$ & $\begin{array}{l}\text { Average Winter } \\
\text { (Dec-Mar) } \\
\text { Precipitation }(\mathrm{cm})\end{array}$ \\
\hline Normal Years & 0.20 & 103.1 \\
\hline El Nino Years & 1.00 & 89.1 \\
\hline La Nina Years & -0.33 & 122.7 \\
\hline $\begin{array}{l}\text { PDO Cycle }(1971- \\
\text { 2000): }\end{array}$ & & \\
\hline $\begin{array}{l}\text { Positive Phase } \\
(1971-1977)\end{array}$ & .13 & 116.5 \\
\hline $\begin{array}{l}\text { Negative Phase } \\
(1978-2000)\end{array}$ & .31 & 99.4 \\
\hline
\end{tabular}

\section{Hydrology}

Abundant precipitation and steep terrain produce a dense network of quickmoving streams draining much of the UCB. Steep gorges generally give way to broader valleys as these tributaries feed the higher-order rivers. An undulating plateau near the crest of the Cascades hosts several small lakes and wetlands. The UCB includes four watersheds ( $5^{\text {th }}$ field hydrologic units) and 19 subwatersheds (6th field hydrologic units), as shown in Figure 10. The Collowash and Upper Clackamas watersheds are free-flowing and dominated by seasonal snowmelt while the Oak Grove Fork watershed is highly regulated for hydropower production, with its flow being determined by managed releases from an earthen dam at Timothy Lake. The majority of flow from the Oak Grove fork watershed is diverted through a pipeline to a downstream generating facility at the Oak Grove Fork powerhouse where it is delivered into the mainstem Clackamas River. The middle Clackamas River watershed receives contributing flow from these three upstream watersheds. 


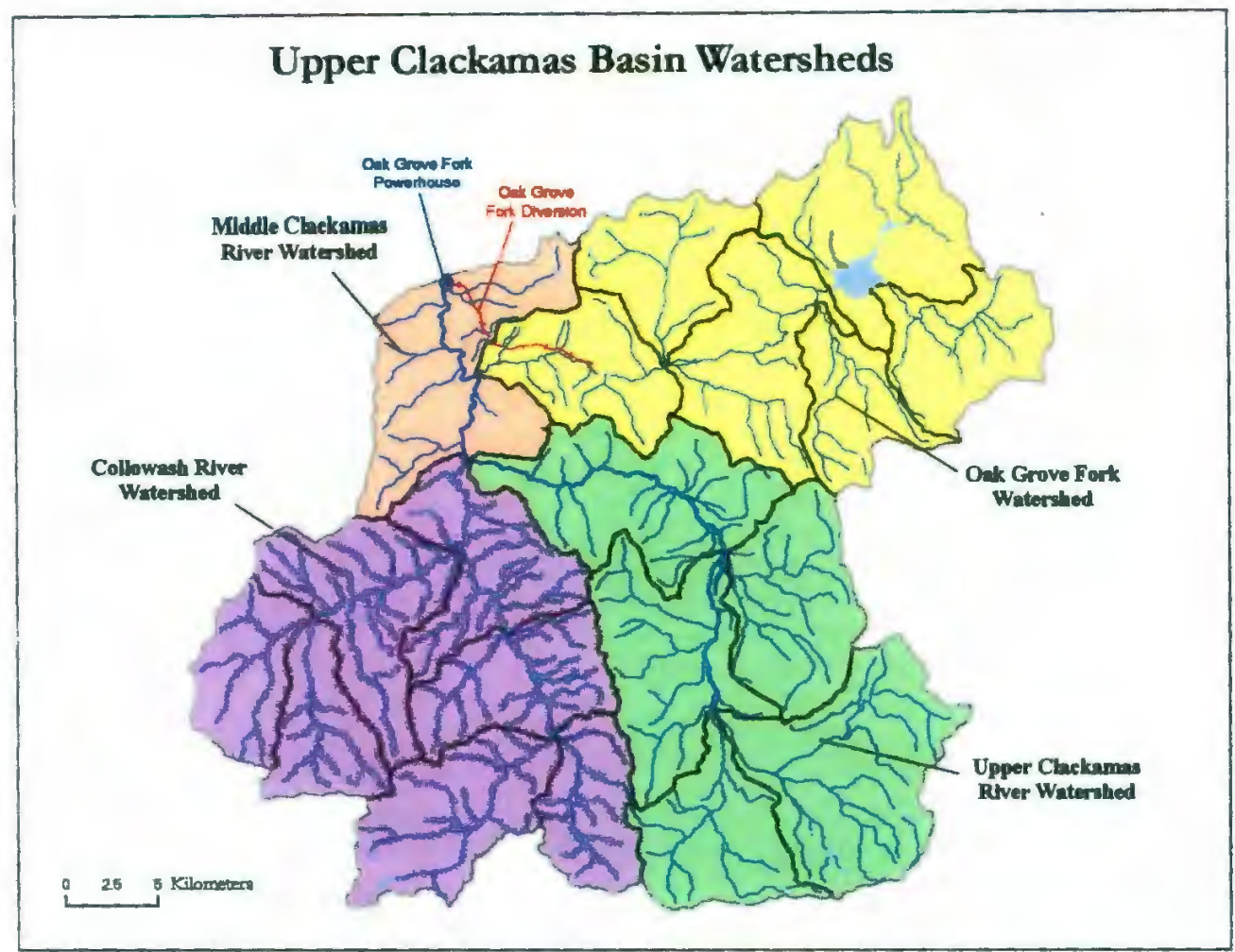

Figure 10: Watersheds of the UCB (data from Regional Ecosystem Office 2003)

The National Ground Water Atlas (US Geological Survey 1994) shows mostly volcanic and sedimentary-rock aquifers underlying the $\mathrm{UCB}$, with portions of the western extent of the study area being underlain by "Pilocene and younger basalticrock aquifers" and "aquifers in pre-Miocene rocks". There is a large regional aquifer system of unconsolidated deposits (the Puget Willamette Trough) that is located downstream of the UCB study area and extends under most of the Willamette lowlands and the Puget Sound region. Volcanic and sedimentary rock aquifers generally consist of a variety of rocks including Pliocene and younger basaltic rocks and semi consolidated sand and gravel.

The storage and recharge/discharge potential of aquifers are related to their permeability and porosity. Unconsolidated deposits generally have a high porosity, 
while the porosity of volcanic and sedimentary rock aquifers is highly variable and depends on whether there is fragmented material, interflow zones, and faults within the rock. In the mountains and foothills of the Cascades, demand for groundwater is low and the terrain is rough, so the hydrogeologic characteristics of volcanic and sedimentary rock aquifers are often unknown (U.S. Geological Survey 1994). In the UCB there are no USGS groundwater monitoring wells, but some research into the groundwater system has been conducted, principally to ascertain its potential for geothermal energy (Ingebritsen et al. 1992; Sherrod et al. 1996). The Oak Grove Fork of the UCB is known to contain relatively permeable lava flows from the Pliocene and Pleistocene eras, which produces a higher groundwater recharge rate than the area below the UCB, where relatively impermeable tuffaceous strata exists (Sherrod et al. 1996). In general, the age of the underlying rocks may be used to estimate the permeability of groundwater aquifers; older rocks lose permeability through hydrothermal alteration of volcanic glass to clays and zeolites and recystallization to higher-temperature minerals (Ingebritsen et al. 1992).

Tague and Grant (2004) delineated the eastern drainages of the Willamette basin into the Western (older) Cascades and High (recent) Cascades (Figure 3) and researched the effect of their underlying geology on the low-flow regimes of their streams. The Western Cascades are dominated by well-drained soils and andesite and basaltic flows, shallow subsurface confining layers, and a well-developed surface drainage network. The High Cascades have poorly developed soils, are underlain by highly porous and permeable volcanic layers, and lack a well-developed surface drainage system. The flow regimes of streams was found to be directly related to the 
proportion of High Cascade geology; catchments with a larger proportion of High Cascade geology experience greater baseflows and less seasonal variation because permeable aquifers play a greater role in the hydrologic cycle. Catchments with a larger proportion of Western Cascades geology experience greater storm peak flows and lower summer base flows because aquifers are relatively impermeable (Tague and Grant 2004). The UCB consists of approximately 50\% High Cascade geology and $50 \%$ Western Cascades geology, and thus is affected by both of these regimes.

\section{Basin Ecology and Water Quality}

The UCB is part of a large area of contiguous forests that extend from the Cascades range west into the valleys. The species compositions of these forests depend primarily on climate, and they are best studied as elevation-dependent zones as described by Dart and Johnson (1981). The valleys and lower elevations are dominated by Douglas-fir and western hemlock trees, with western red cedars often found growing in the well-watered soils of stream valleys. Douglas-firs grow quickly after disturbances (such as fires) while Western hemlocks are shade-tolerant and are the climax species when forests are undisturbed for long periods. At elevations around 1,100 meters, lower temperatures and greater precipitation favor a shift to true fir species (Pacific silver, noble fir, and subalpine fir), the mountain hemlock, and in moist soils, the Engelmann spruce. The trees of this range are diminished in size because of the harsher conditions, and the band of the true fir zone is relatively narrow. Subalpine forests occur above about 1,500 meters in elevation, where snow accumulations are greater, the grower season is shorter, slopes are steeper, and soils 
are generally shallow. Trees from the species of the true fir zone are represented here, but are generally smaller in stature and may be accompanied by lodgepole pine, whitebark pine, and alpine larch (Dart and Johnson 1981). A few craggy peaks extend above treeline (around 1,700 meters) in the UCB, offering panoramic views of the extensive forests located below and serving as likely locations for small populations of alpine vegetation (mosses, sedges, and lichens).

Omernik (1987) and the U.S. EPA (1995) produced a hierarchical system of ecoregions for the U.S. E.P.A. This system delineates ecoregions based on multiple geographic characteristics as causes or indicators of ecological conditions. The UCB includes parts of three different ecoregions, which are shown and described in Figure 11.

\section{Ecoregions of the Upper Clackamas Basin}

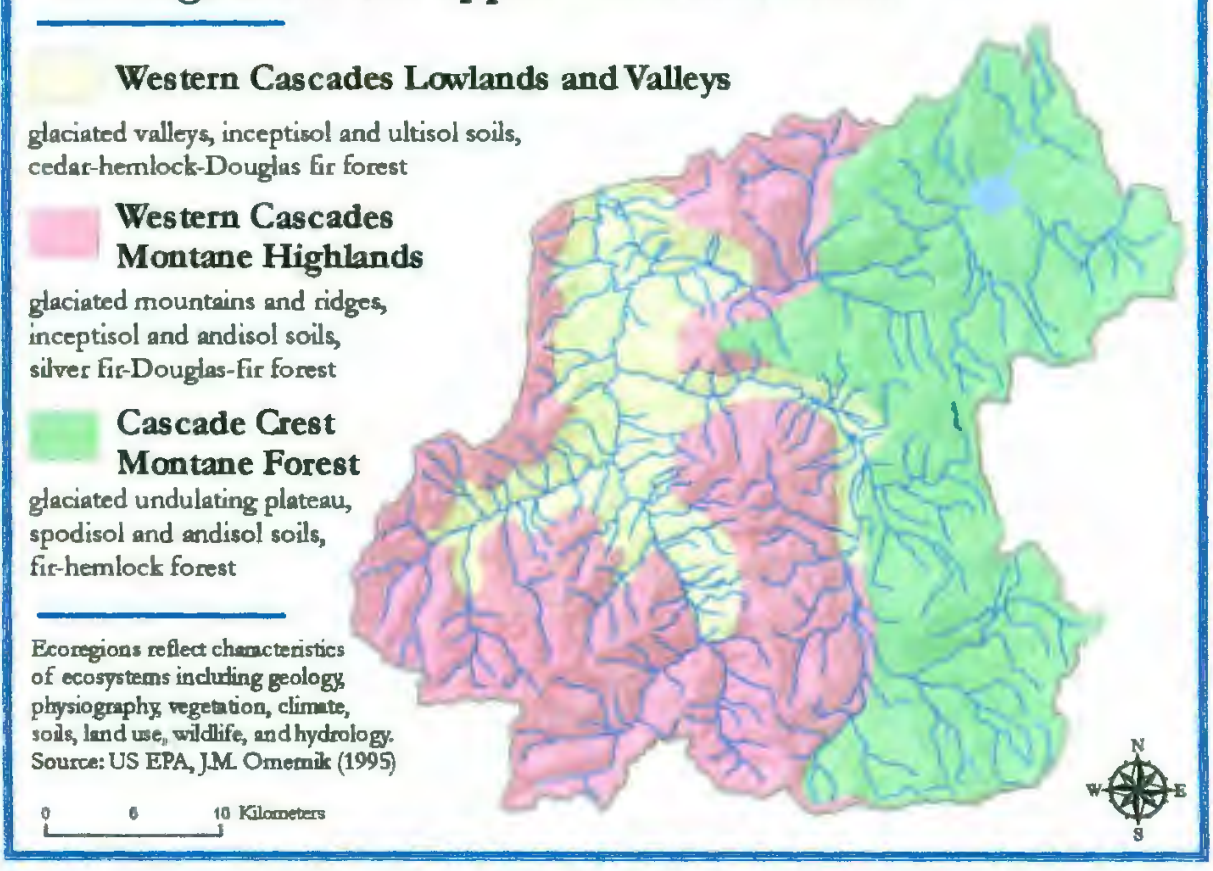

Figure 11: Ecoregions of the UCB (data from Omernik 1987 and U.S. EPA 1995) 
Four runs of anadromous salmonids (spring Chinook, Coho, and winter and summer Steelhead) migrate through and spawn in the upper reaches of the Clackamas river system (StreamNet 2004). Limiting factors to salmon habitat include natural barriers such as waterfalls and high temperatures $\left(>15^{\circ} \mathrm{C}\right)$ in some unshaded riparian areas of the Upper Collowash and Clackamas rivers (ODFW 1999). Dissolved oxygen is closely correlated to water temperature in the basin, and is also a limiting factor for salmon spawning.

In 1998, the US Geological Survey conducted a comprehensive water quality assessment of the Clackamas River Basin, with an emphasis on nutrient and algal conditions (Carpenter 2003). Basic water quality parameters (dissolved oxygen, $\mathrm{pH}$, temperature, flow, and conductance) were assessed at several sampling locations in the upper and lower mainstem and tributaries of the Clackamas. While the streams of the UCB generally have high water quality, Carpenter (2003) found several negative conditions that exist during parts of the year: (1) high temperatures and low dissolved oxygen levels at some sites during low flow periods of the late summer, although these measurements are instantaneous and state water quality standards are based on longer (7 or 30 day) criteria; (2) increased nutrients in streams, likely from forest management practices including the erosion of phosphorus from phosphate-rich soils; and (3) high temperatures and increased phosphorous (possibly from blue-green algae blooms) in the Oak Grove Fork when releases occur from the Timothy Lake reservoir. 


\section{Land Use}

Taylor (1999) offers a well-researched description of the historical human habitation and land use in the Clackamas River Basin. Up to 10,000 years ago, various bands of Native Americans traveled throughout the Lower Columbia region, and large, permanent villages were probably established on the lower Clackamas River floodplain between 2,000 and 3,000 years ago by the Clackamas Indians Tribe (est. pop: 1,800 ). During the early 1800 's, the Clackamas Indians were heavily impacted by introduced epidemics, and by mid-century only 88 tribal members remained. In 1855, the Clackamas Indians ceded their lands to white settlers and many resettled to other areas.

Oregon City was founded near the confluence of the Clackamas and Willamette Rivers in 1829 by white settlers, and became the first incorporated city west of the Rocky Mountains in 1846 (City of Oregon City 2000). Increasing human settlement, water pollution, habitat degradation, and dam building on the Willamette and lower Clackamas Rivers subsequently contributed to a sharp decline of salmon and steelhead (Taylor 1999). Aside from impacts to salmon and steelhead runs, the UCB remained mostly unaffected by human settlement at the beginning of the 20th century. Abundant opportunities for hydropower development provided the incentive to develop transportation into the upper basin. In the early 1900 s, a railway was built through to Estacada, and the newly incorporated city became the center of hydropower development on the river. The Cazadero Dam was constructed upstream of Estacada in 1907, and the River Mill Dam was completed downstream of Estacada in 1911 (Taylor 1999). In 1921, a road was extended to the Oak Grove Fork hydropower 
project, located near the lowest point of the study area for this thesis. A compactedearth dam was completed in 1956 on the upper Oak Grove Fork, converting Timothy Meadows into a $5.7 \mathrm{~km}^{2}$ (1,400-acre) reservoir (Timothy Lake), which has since been used for storage for the hydropower system. The North Fork Dam was completed in 1958, adding substantial capacity to the Clackamas River hydropower system (Taylor 1999).

A steady expansion of the road network followed, and the Clackamas River Basin currently contains approximately 790 kilometers of roads (Taylor 1999). New roads opened up large areas of the upper basin that were previously difficult to access, and this facilitated an increasing timber harvest, which continued until the mid-1990's. Between 1950 and $1970,33.5 \mathrm{~km}^{2}$ (8,273 acres) of timber were cut in the UCB, while during the period between 1970 and $1994,85 \mathrm{~km}^{2}$ (21,000 acres) were cut. In all, over $29 \%$ of the upper basin was harvested for timber during the 1950-1994 period (Taylor 1999). Some mining also occurred in the UCB, including prospecting for gold, silver, and copper during the 1910's, and cinnabar in the 1930's and 1940's, which produced sizable quantities of mercury in the Oak Grove Fork (Taylor 1999).

Logging still occurs throughout the upper basin today, albeit at a slower pace (Taylor 1999). Cut areas in various stages of regrowth are evident, and persistent land use effects of logging on the watershed include increased erosion, elevated water temperatures, and the removal of pool habitat and large woody debris in streams. The long-term effects of road building include erosion of nearby hillsides and sedimentation of streams, and the re-alignment of many stream and river segments. 
Landslides are also a frequent occurrence on the roads of the UCB (Sherrod et al. 1996).

In Oregon, there has been considerable research into the effects of timber harvesting on hydrology. Research has shown that the logging of the forests of western Oregon increase runoff, at least initially (Harr et al. 1979; Jones 2000). Areas that have been logged show less evapotranspiration because of the loss of vegetation and greater overland flow because of soil compaction, both of which lead to higher peak, seasonal, and annual flows from a catchment (Harr et al. 1979). Jones (2000) found that this effect on peak flows may diminish considerably and possible reverse itself as regrowth occurs.

Today, the CRB is an important source of water resources for multiple uses. The four major dams on the Clackamas River generate a total annual average of 758 million kilowatt-hours per year of electricity for Portland General Electric (PGE 2003). The basin provides municipal water supplies for approximately 175,000 people (The League of Women Voters 2002). The close proximity of the UCB to Portland and its many natural attractions has also made it increasingly popular for recreation, including camping, hiking, angling, hunting, white-water boating, and scenic drives. Current land cover in the UCB is mostly forested and contains virtually no development aside from the road network, hydropower facilities, and a few homes and buildings. Logging has occurred throughout much of the basin except for the Bull of the Woods wilderness area, which is permanently protected in a roadless state and covers an area of $108 \mathrm{~km}^{2}(8.5 \%$ of the study area). $5.9 \%$ of the UCB was classified 
as "transitional" in a 1992 assessment (see Figure 12), consisting predominantly of cut areas that are regenerating (USGS, 1999).

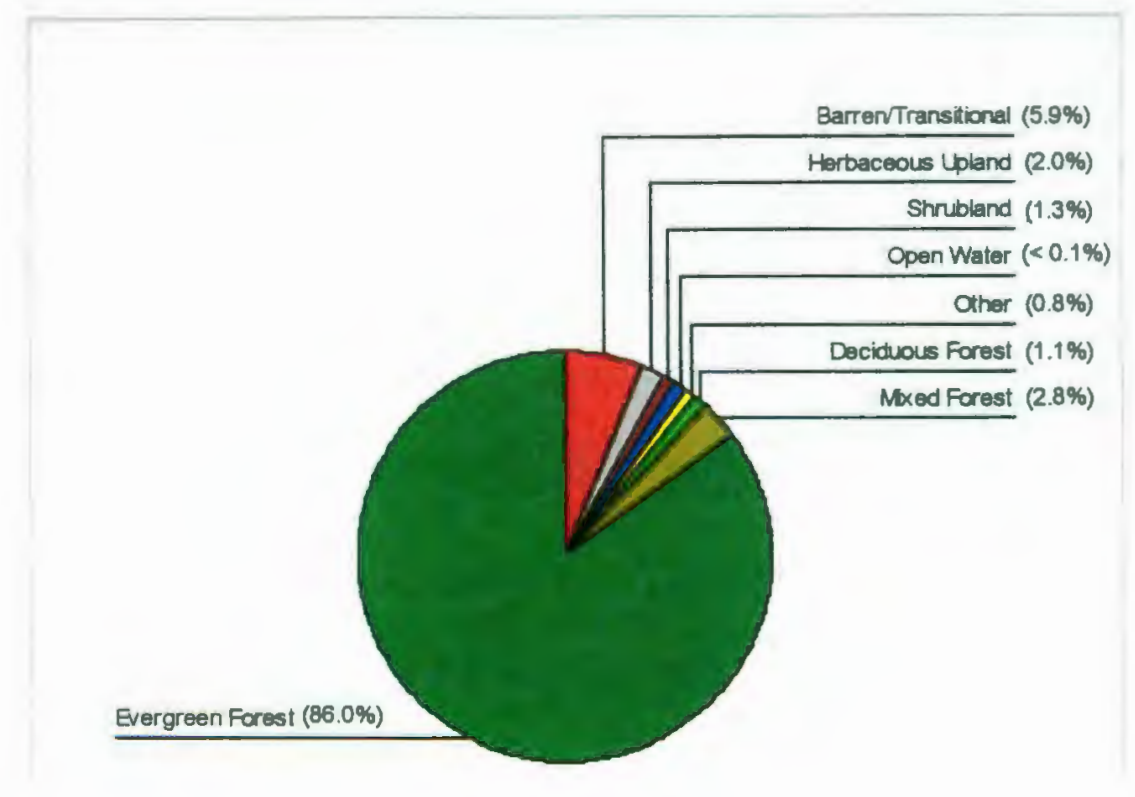

Figure 12: 1992 Land cover of the UCB (data from USGS 1999) 
I chose the STATSO database and the USGS land cover data set to estimate the Curve Number for each pixel of the study area because they are the finest available data for the UCB. The STATSGO database contains the hydrologic group of each soil component, where $\mathrm{A}=$ High infiltration, $\mathrm{B}=$ Moderate infiltration, $\mathrm{C}=$ Slow infiltration, and $\mathrm{D}=$ Very Slow Infiltration. Because multiple soil components occur within each map unit, it was necessary to first quantify these categories $(A=1, B=2$, $\mathrm{C}=3, \mathrm{D}=4$ ) in order to calculate a unit average. The results of this analysis are shown in Figure 13.

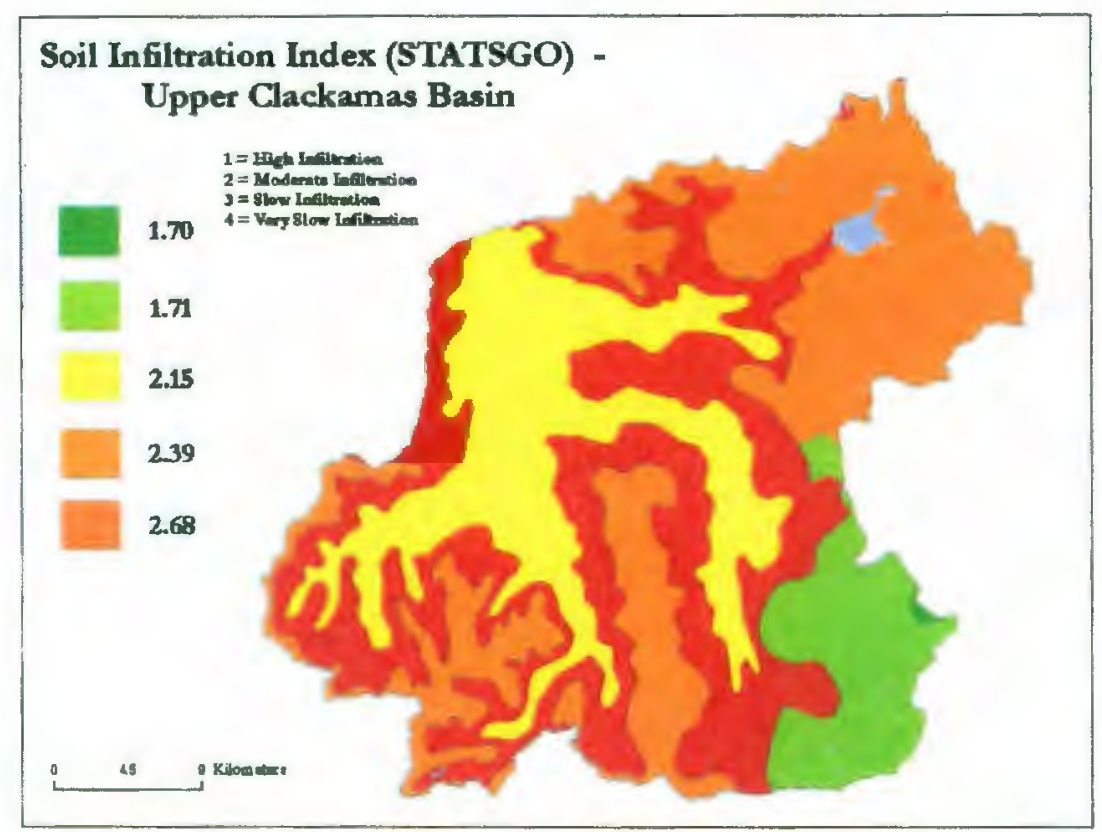

Figure 13: Soil infiltration by map unit (data from Natural Resource Conservation . Service 1997)

I used a table from Dunne and Leopold (1978) to calculate SCN from the soil hydrologic group and the land cover. The results (Figure 14) show high SCN values in transitional (clear-cut) areas, indicating slower infiltration rates, but the influence of the soil hydrologic groups are still very apparent throughout the study area. A higher 
SCN indicates larger direct runoff volumes, while a lower SCN indicates higher infiltration into the soil.

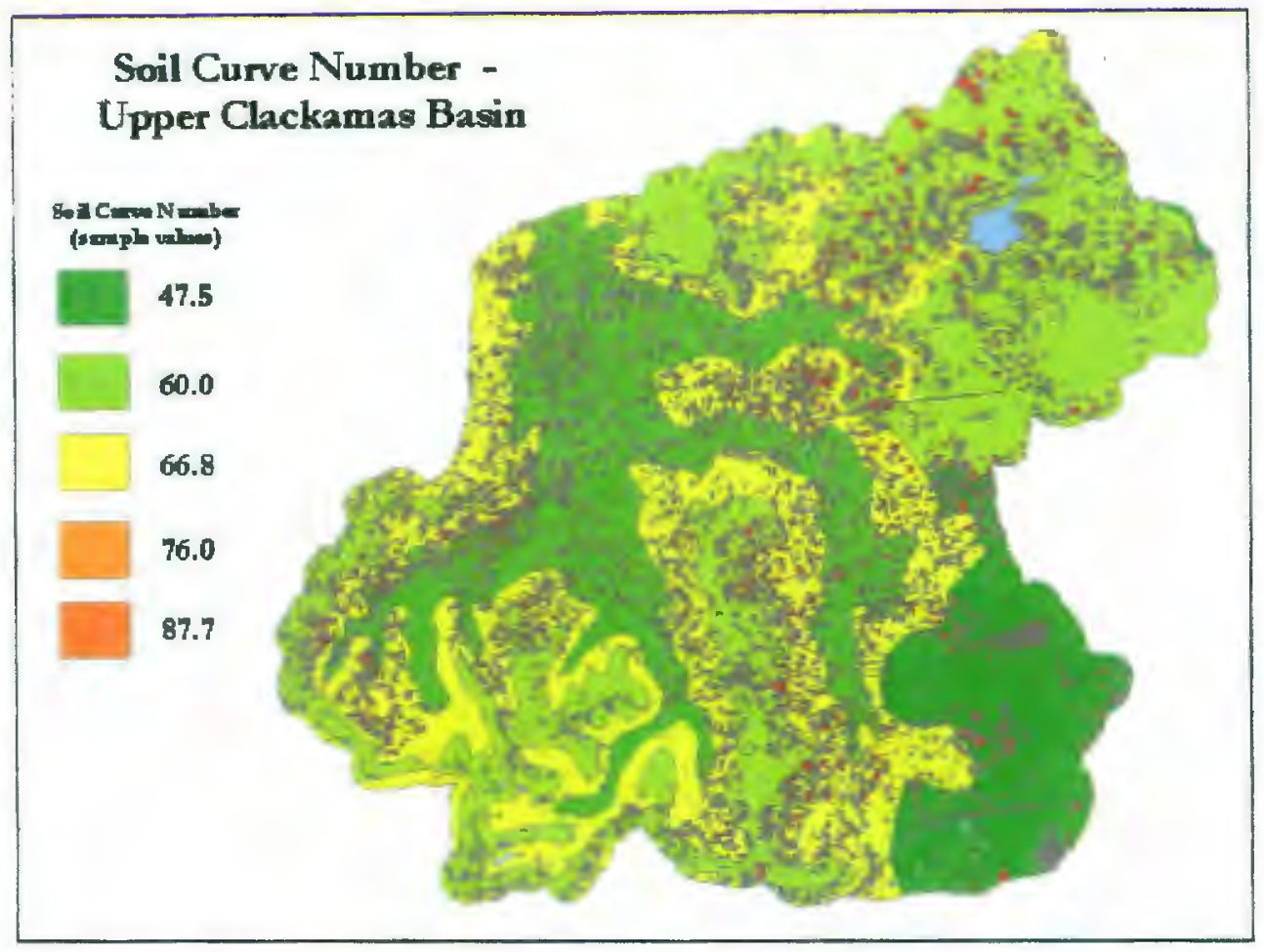

Figure 14: Soil curve number - UCB (source data from Natural Resource Conservation Service 1997)

The Struma hydrologic model also requires the soil field capacity to determine the amount of moisture that is readily available for evapotranspiration and runoff each month. The STATSGO data provides Available Water Content (AWC) in dimensionless units (capacity/layer depth) as a high and low value for each component and layer of the soil. The following procedure, documented in the STATSGO User Guide (NRCS 1997), was used to determine the average AWC for each map unit: (1) Average the AWC high and low values for the mean AWC of each soil layer. (2) Multiply mean AWC by the depth in inches of the corresponding layer of soil. 
(3) Add these values together for each component group and then multiply this value by the percentage of the soil map unit that the component represents.

(4) Add these component values for each map unit to determine the average depth in inches of AWC for each map unit.

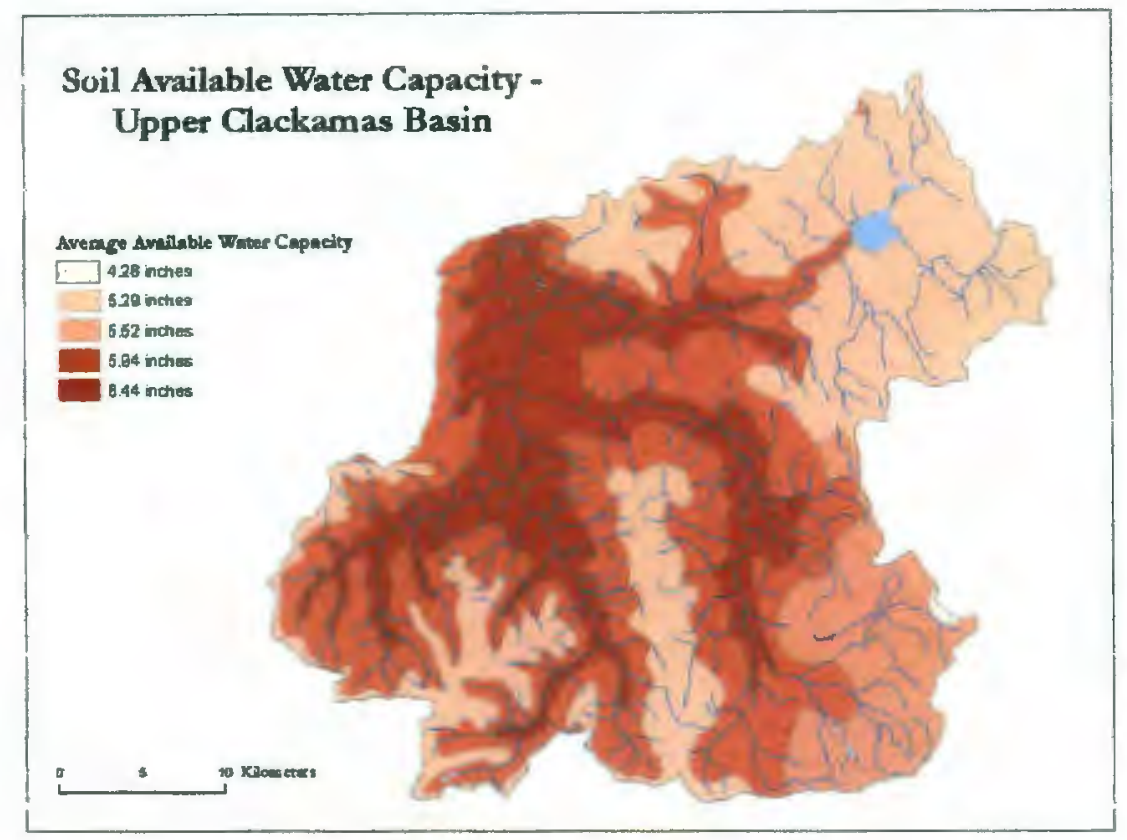

Figure 15: Soil available water capacity - UCB (source data from Natural Resource Conservation Service 1997)

The results (Figure 15) show that the highest average available water capacity exists in the soils of the lower river valleys, while lower available water capacities are found in the higher elevation areas, particularly in the mountainous areas of the south. The hydrologic model requires Field Capacity (FC) as the total water holding capacity of the soil. FC is the sum of the AWC and the water content unavailable to plants, which is stored in the soil below wilting point. Dunne and Leopold (1978) give estimates of the proportion of soil moisture (volume) at which the wilting point occurs based on soil texture, and these range from $4 \%$ for sand to $25 \%$ for clay. The 
STATSGO database provides soil texture by layer, so I used this to determine the WP of each soil map unit based on the method from Dunne and Leopold (1978).

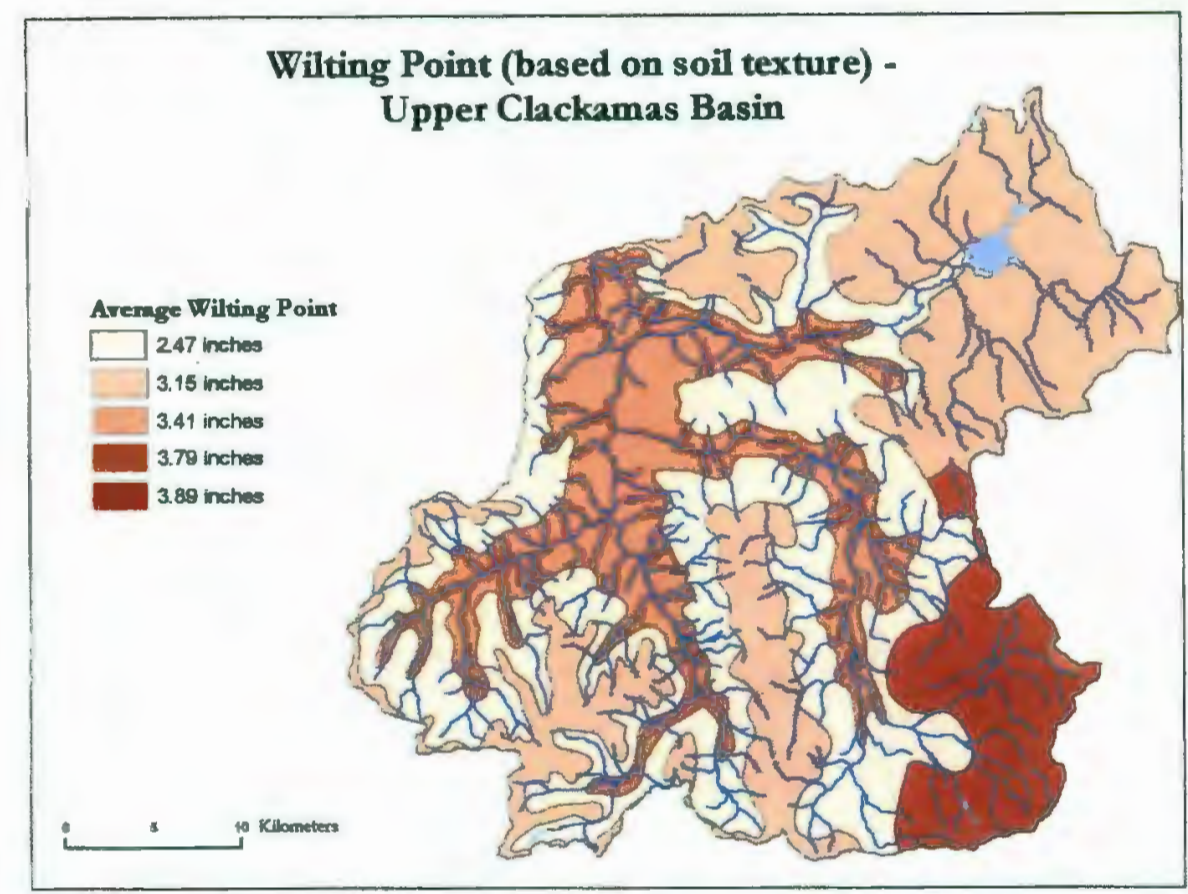

Figure 16: Wilting point of soils - UCB (source data from Natural Resource Conservation Service 1997)

As shown in Figure 16, the highest clay contents are found in the plateau area in the southeast, and this area is therefore calculated to have the highest wilting point (3.89 inches). This means that plants, on average, will be expected to permanently wilt when there is 3.89 inches or less of water in the soil profile here because the clay particles bind this water too tightly for it to be removed. The areas adjacent to and draining into the major valleys were estimated to have the lowest wilting point $(2.47$ inches) because of their relatively low clay content, meaning that plants should be able to obtain water until the moisture content in the soil falls below this point. 
For each map unit, FC was calculated as AWC + WP, assuming that the total water capacity of the soil (FC) is equal to the sum of the volume of water capacity available to plants (AWC) and the sum of the volume of water capacity unavailable to plants (WP). These results are shown in Figure 17.

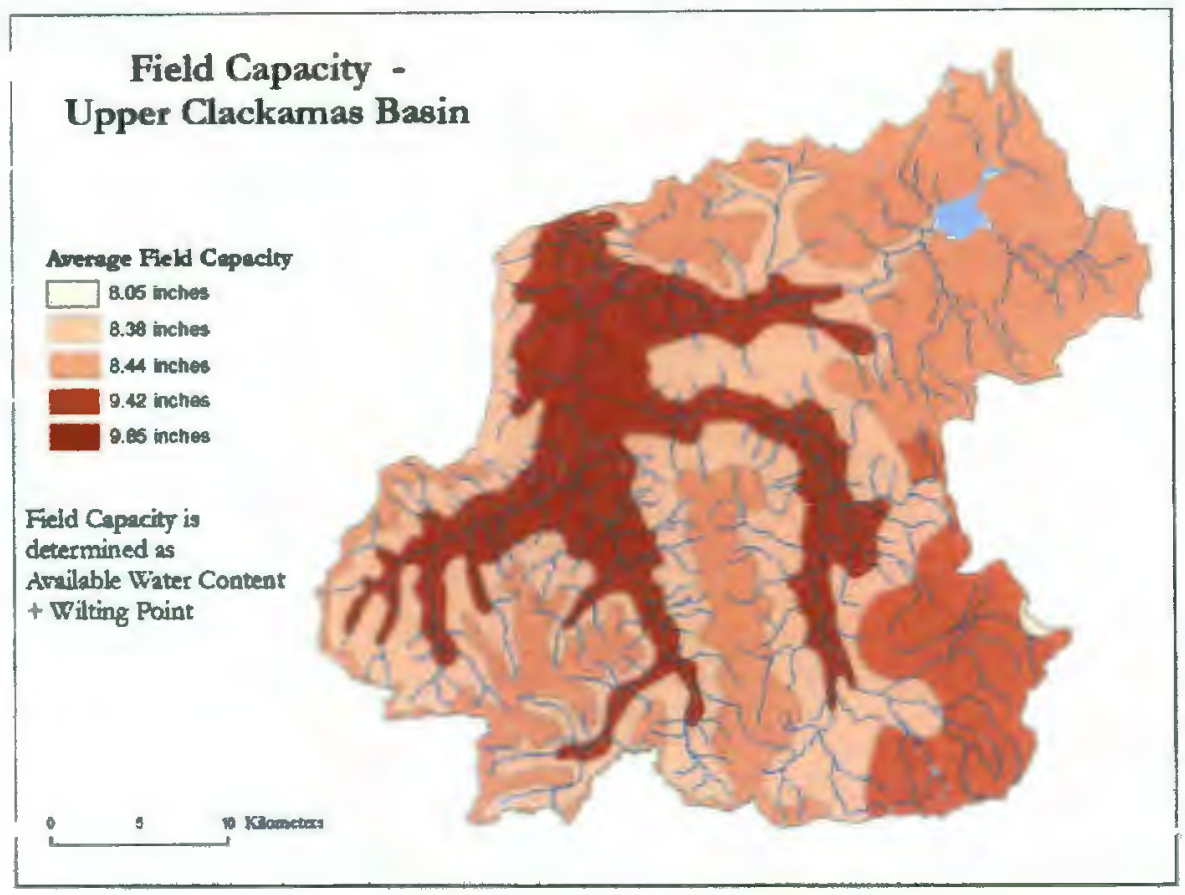

Figure 17: Field capacity - UCB (source data from Natural Resource Conservation Service 1997)

The soil field capacity ranges from a maximum of 9.85 inches in the lower valleys to a minimum of 8.05 inches in the steep areas adjacent to the valleys. These characterizations are coarse and there is likely significant spatial variation within the soils of these map units. These summaries are therefore a simplification of the soil characteristics and processes that occur throughout the study area, but provide a measure of field capacity based on the best available soil data for this region. 


\section{Data Construction for Gridded Study}

Data sets were downloaded in a GIS format (historical modeled climate data from the Spatial Climate Analysis Service (Oregon Climate Service 2005), land cover data from the U.S. Geological Survey (1999), digital elevation model data from the U.S. Geological Survey - EROS Data Center (1999) and soils data from the Natural Resource Conservation Service (1997). These data were reprojected to a UTM (zone 10) coordinate system, clipped to the study area, and then intersected with a study grid to determine the characteristics of each cell of the grid. The study grid was derived by dividing the study area into $1 \mathrm{~km}^{2}$ cells, producing a total of 1,264 cells. A $1 \mathrm{~km}^{2}$ cell resolution was used because it allows for a manageable amount of data and computer processing and is not too fine to analyze the coarse climate and soils input data with.

A GIS operation named 'zonal statistics' was used to intersect soils, elevation, and land cover data with the study grid and derive values for each cell. Where multiple characteristics occurred within a single cell, these values were averaged according to their relative coverage. Land cover data were preserved in output tables when multiple categories occurred in one cell (for example, one cell might be recorded as $80 \%$ coniferous forest, $15 \%$ barren/transitional, and $5 \%$ open water). Climate data consisted of 1080 separate data sets (grids) that were downloaded from the PRISM web site, because the simulation is run for 360 months (1971-2000), and there are three categories of climate inputs: temperature, precipitation, and humidity (Oregon Climate Service 2005). I wrote batch processes in ArcGIS software to reproject each of these climate data sets, resample them to the finer $1 \mathrm{~km}^{2}$ cell resolution using a 
All input data for the cells were then moved into an Access database. I chose a relational database to store and run the model instead of a GIS for a few reasons:

(1) Once the input data is collected, the hydrologic model performs mathematical operations on individual cells without considering the relationship of these cells to each other. By assigning a unique identifier code to each cell, it is possible to model processes outside of a GIS environment and then relate the results back to the original grid to visualize and analyze them in a map format.

(2) Running a model in a relational database such as Access offers faster performance than GIS software because it operates on records in tables rather than spatial data.

(3) Access offers a stable environment to run long processes.

Some further processing of the input data was necessary to convert it to the format required by the model. PRISM provides dew point measurements but the model requires relative humidity. I used Bolton's method (1980) to compute relative humidity from a dew point, approximating actual and saturation vapor pressures based on monthly dew point and temperature values:

$$
\begin{aligned}
& \mathrm{E}_{\mathrm{s}}=6.112 \times \exp ((17.67 \times \mathrm{T}) /(\mathrm{T}+243.5)) ; \\
& \mathrm{E}=6.112 \times \exp \left((17.67 \times \mathrm{Td}) /\left(\mathrm{T}_{\mathrm{d}}+243.5\right)\right) ; \\
& \mathrm{RH}=100.0 \times\left(\mathrm{E} / \mathrm{E}_{\mathrm{s}}\right) ;
\end{aligned}
$$

where $E_{s}=$ saturation vapor pressure in $\mathrm{mb} ; \mathrm{E}=$ vapor pressure in $\mathrm{mb} ; \mathrm{T}_{\mathrm{d}}=$ dew point; $\mathrm{T}_{\mathrm{a}}=$ Temperature; and $\mathrm{RH}=$ Relative Humidity $(\%)$. 


\section{Model Structure and Implementation}

The Struma River model is a conceptual, distributed simulation that approximates some of the physical processes of a watershed through monthly parameter-based operations on each pixel of a GIS study grid. This model uses the Thorthwaite Water Balance method and has five major components that approximate physical processes: (1) rain/snow precipitation; (2) snow cover and snowmelt; (3) infiltration/direct runoff; (4) soil moisture/evapotranspiration; and (5) indirect runoff. Figure 18 shows the inputs, processes, and outputs of the model; the structure of this model is somewhat different than the original Struma model structure (all modifications are discussed in detail in Chapter V). The following paragraphs describe the equations that are used to simulate hydrologic processes in each study cell and are replicated from Knight et al. (2001).

Equation 2 estimates proportion of precipitation falling as snow and the proportion falling as rainfall based on monthly air temperature (T) (Legates 1991). This equation provides a good estimation of snowfall when available data are limited to monthly precipitation and temperature data:

$$
\text { Snow }(\%)=100 /\left(1.35^{\mathrm{T}} \times 1.61+1\right) \text {. }
$$

The snowpack accumulation is calculated and stored for each cell of the study grid as Snow Water Equivalent (SWE).

A linear degree-day (temperature index) approach models snowmelt. The premise of this approach is that precipitation accumulates as snow below a certain temperature and that melting occurs above a certain temperature, based on a melt rate 
factor (MRF), which is determined by land cover characteristics. The MRF is calculated with a method described by Semadeni-Davies (1997): the proportion of forest cover of each pixel is determined by land cover, and the MRF is multiplied by 2.0 for the forested area proportion and by 3.0 for the non-forested area proportion. The monthly snowmelt (SWE) is then calculated with the linear degree-day approach (Kuchment and Gelfan 1996; Semadeni-Davies, 1997):

(3) Snowmelt $(\mathrm{cm})=M R F \times($ monthly air temperature - snowmelt temperature $) \times$ days/month.

The equation allows one to adjust the snowmelt temperature during model calibration, but generally $0^{\circ} \mathrm{C}$ is assumed unless empirical data suggests otherwise. Once calculated, snowmelt is assumed to percolate through the snowpack and infiltrate into the soil, and is accumulated with the soil moisture of the study cell.

Infiltration of rainfall versus direct runoff is calculated next, using the Soil Curve Number (SCN) method. As mentioned earlier, direct runoff and infiltration are dependent on the intensity of rainfall, but Ferguson (1996) describes a reasonable approach for calculating direct runoff (DR) for monthly data. Rainfall data is converted to inches and direct runoff is calculated as:

$$
\begin{aligned}
& \mathrm{DR}=-0.095+0.208 \times \text { rainfall } / \mathrm{S}^{0.66} \\
& \mathrm{~S}=1000 / \mathrm{SCN}-10
\end{aligned}
$$

All rainfall that is not direct runoff is assumed to infiltrate into the soil and is added to the soil moisture of the study cell. 
A soil water balance accounting approach is used to determine evapotranspiration and track monthly soil moisture. This approach offers the advantages of fairly simple data requirements and flexibility, while still including important physical processes (Knight et al. 2001). Potential Evapotranspiration (PE) is determined with the Ivanov equation (Equation 6), which extends beyond traditional methods by incorporating relative humidity and allowing for ablation during cold periods:

$$
P E(\mathrm{~mm})=-0.0018 \times(\text { Relative Humidity }-100) \times(\text { Temperature }+25)^{2} .
$$

PE is multiplied by the pan evaporation coefficient $(0.67)$ to avoid overestimation, and is multiplied by a daylight coefficient based on the monthly fraction of annual hours of daylight in each month, taken from Dunne and Leopold (1978). Finally, PE is adjusted by the vegetative cover to account for increased transpiration that can be expected to occur in forested areas vs. non-forested areas: (7) $\quad$ Monthly $\mathrm{PE}=\mathrm{PE} *($ Fraction of Forest $)+(1-$ Fraction of nonforest $) \times 0.8$. 


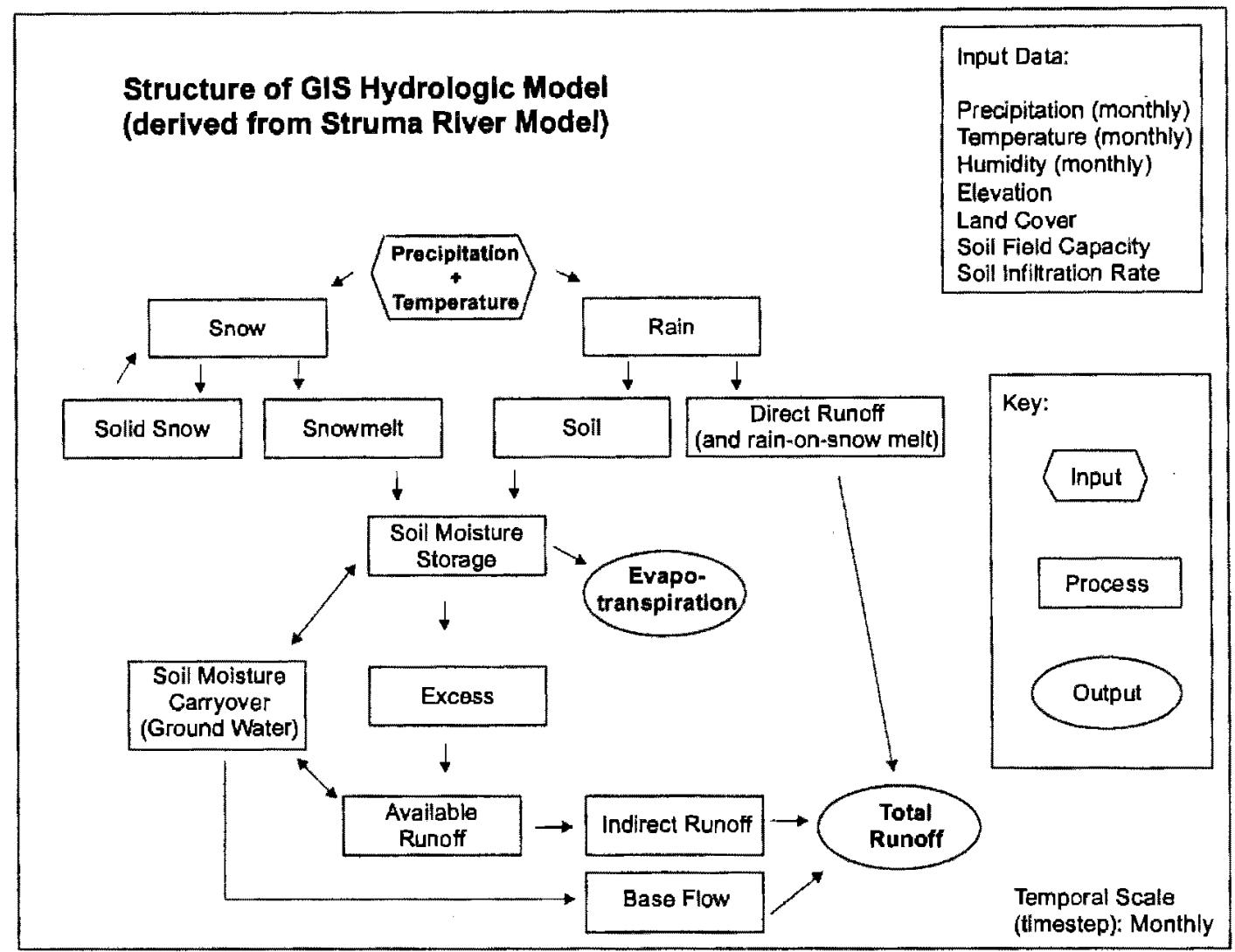

Figure 18: Structure of GIS hydrologic model (modified version of diagram shown in Knight et al. 2001)

Next, Actual Evapotranspiration (AE) is determined with the Thornthwaite method, which calculates the actual loss of moisture depending on the water available in soil and vegetation. Soil moisture for each cell is stored monthly and compared to the field capacity of the soil to store water. If the soil moisture is less than field capacity, then a soil moisture deficit exists, and:

$$
\mathrm{AE}=\mathrm{PE} \times(\text { Soil Moisture/Field Capacity). }
$$

If soil moisture is greater than field capacity, then $\mathrm{AE}$ equals $\mathrm{PE}$, and excess moisture is available as runoff. $\mathrm{AE}$ is then subtracted from the soil moisture balance and assumed to escape from the watershed. 
The last model component calculates indirect runoff (throughflow) from the soil. This component is meant to account for the moderated release of surplus moisture from the soil and also for the delay in timing for runoff to enter the stream network when it is stored in wetlands, lakes, or other temporary storage reservoirs in the landscape. Outside of the Timothy Lake basin (which is not modeled for the reasons discussed below), only $0.523 \%$ of the land cover is classified as wetlands and $0.176 \%$ of the land cover is classified as open water, suggesting that it may be reasonable to assume that these mediums do not cause a significant delay in runoff from the study area. (US Geological Survey 1999).

As with the PE component, the moisture surplus of the soil is the amount of water in the soil above field capacity. Indirect runoff is then calculated to occur only from the surplus of moisture in the soil. In other words, if there is no soil surplus, then no indirect runoff occurs (although a second component (base flow) was added to the model and is discussed at the end of this chapter). Indirect Runoff is simply calculated as the Soil Moisture Surplus multiplied by the Indirect Flow proportion. Values for the Indirect Runoff proportion may vary widely depending on the size and characteristics of a watershed; in the Struma River study a value of 0.2 was used, but in this study, this parameter was calibrated differently (described in Chapter V). In general, a longer lag can be expected in larger basins because water must travel through a larger area, but this rate is also affected by other characteristics of the basin including gradient, soil, geology, and human modifications.

Finally, total runoff is calculated in each pixel as the sum of direct runoff and indirect runoff. Total runoff from each cell is assumed to directly enter the stream 
network within the month that it leaves the study cell, and is aggregated for the entire study area except for the Timothy Lake basin. Timothy Lake is part of the Oak Grove Fork watershed, which includes a small diversion without storage at Stone Creek, and a larger diversion of most of the flow of the Oak Grove Fork through two small lakes (Harriet and Frog lakes) to the Oak Grove Powerhouse (see Figure 19). At the second managed storage diversion (from the Oak Grove Fork to the powerhouse), flow is stored only for daily fluctuations in hydrologic demand, so it has no relevance for the monthly time-scale of the model. Storage and release at Timothy Lake do affect monthly flows, however. Actual monthly data of managed releases from a flow gage located directly below the Timothy Lake outlet (USGS gage \#14208700) are therefore used instead of modeled flow estimates for the Timothy Lake basin and added to the total direct runoff of the study area during all model runs (calibration, validation, and climate change assessment).

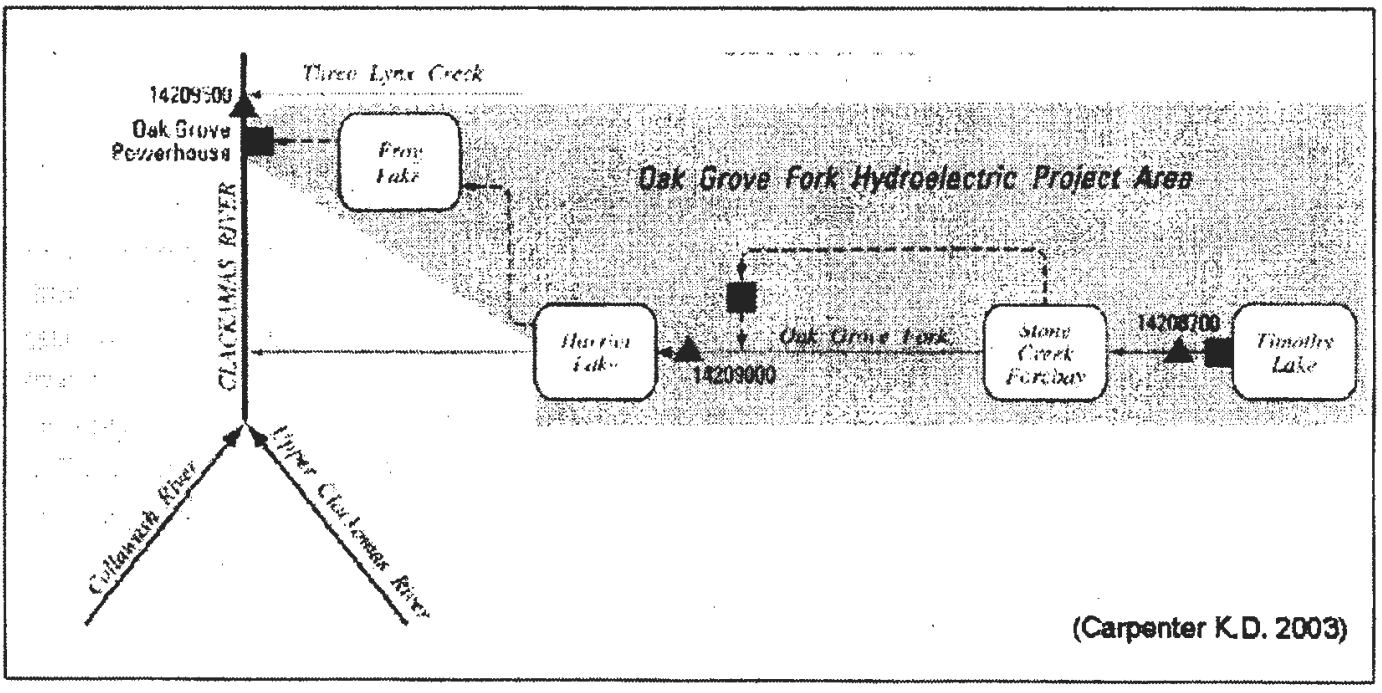

Figure 19: Diagram of water management in the Oak Grove Fork watershed (squares $=$ dams, triangles $=$ gages) $($ figure from Carpenter 2003) 
I programmed each of the model components in an Access database with Visual Basic for Applications (VBA) scripting language. I then tested this program extensively, evaluating each component individually to ensure that it was running correctly without errors. The program simulates multiple years of hydrologic processes by looping through each month, running each component of the model in this sequence. Within each of these components, the model loops through each cell of the study area, reading input data and outputting results to a table for that month. In addition to total runoff by month, it also records rainfall, snowfall, snowmelt, infiltration, potential evaporation, actual evaporation, direct runoff, indirect runoff, snowpack, and soil moisture for each study cell during each month of the simulation. Because these data are related to a GIS study grid, it is possible to map any of these attributes to examine the output of the model for a particular month and location. Initial cell soil moisture is determined by using the average (15-year) October 1 soil moisture for each cell from the final (calibrated) simulation run (1971-1985).

The original Struma River model was adapted in a few ways during the calibration process to account for the different characteristics of the UCB: (1) A base flow runoff was added, which computes the proportion of moisture stored below the field capacity of the soil that contributes to indirect runoff from the surplus soil moisture; (2) A rain-on-snow melt process was added to account for snowmelt that is forced by large rainfall events; (3) Direct runoff is allowed to occur when snow cover exists; (4) An increase in the rate of direct runoff during December and January was added to the model to account for higher intensity rainfall intense rainfall events and a lower vegetative cover during these months. 
Irrespective of its statistical performance, the conceptual model has several limitations. Runoff is dependent on a number of complex physical factors outside the scope of this analysis, and may be affected over time by changes in landscape characteristics such as forest removal and regrowth (Jones 2000). Table 3 shows a list of assumptions and processes that are not modeled. While these assumptions are simplifying and ignore hydrologic processes that are likely to affect runoff from the study area, they are omitted based on the available data and the spatial and temporal scales used, and are intended to produce a practical simulation that is a compromise between an overly complex model and an oversimplified one. The coarse scale (both temporal and spatial) of the model limit the detail of the processes that may be simulated and the precision of their results, but are appropriate for the available input data and time constraints of the study. 
Table 3: Processes not simulated in hydrologic model

\begin{tabular}{|l|l|}
\hline $\begin{array}{l}\text { PROCESS NOT } \\
\text { MODELED }\end{array}$ & RATIONALE \\
\hline Redistribution of snow & $\begin{array}{l}\text { The redistribution of snow is assumed to be } \\
\text { negligible at the } 1 \text { km spatial scale. }\end{array}$ \\
\hline $\begin{array}{l}\text { Effect of aspect on } \\
\text { snowmelt }\end{array}$ & $\begin{array}{l}\text { The broad-scale effects of aspect are already } \\
\text { assimilated into the input temperature data. } \\
\text { The fine-scale effects of aspect are assumed to } \\
\text { be negligible at the } 1 \text { km spatial scale. }\end{array}$ \\
\hline $\begin{array}{l}\text { Refreeze and water } \\
\text { retention within the } \\
\text { snowpack }\end{array}$ & $\begin{array}{l}\text { This process is assumed to have a negligible } \\
\text { effect at the monthly time scale. }\end{array}$ \\
\hline $\begin{array}{l}\text { Changes in land cover } \\
\text { The model is designed to assess the effects of } \\
\text { climate change, not land cover change, and it } \\
\text { uses recent USGS land cover data (1992) for } \\
\text { consistency in all analysis. }\end{array}$ \\
\hline $\begin{array}{l}\text { Effect of fog drip on } \\
\text { precipitation. }\end{array}$ & $\begin{array}{l}\text { This process is assumed to be captured in the } \\
\text { input precipitation data. }\end{array}$ \\
\hline $\begin{array}{l}\text { Effects of interception on } \\
\text { precipitation and } \\
\text { evaporation }\end{array}$ & $\begin{array}{l}\text { The effect of interception on precipitation is } \\
\text { assumed to be captured in the precipitation } \\
\text { data. The effect of interception on evaporation } \\
\text { is not included because of inadequate data } \\
\text { available to simulate this process. }\end{array}$ \\
\hline $\begin{array}{l}\text { Effect of slope on soil } \\
\text { absorption and runoff }\end{array}$ & $\begin{array}{l}\text { These processes are assumed to be negligible at } \\
\text { the 1 km spatial scale. The input STATSGO } \\
\text { soils data captures the broad-scale effects of } \\
\text { topography on soil characteristics. }\end{array}$ \\
\hline $\begin{array}{l}\text { Effects of subsurface } \\
\text { aquifer } \\
\text { recharge/discharge and } \\
\text { inter-basin transfers } \\
\text { These processes are not modeled because of } \\
\text { insufficient available information about aquifers } \\
\text { modeled, however, as indirect runoff and } \\
\text { baseflow based on soils and underlying geology. }\end{array}$ \\
\hline
\end{tabular}




\section{MODEL CALIBRATION AND VALIDATION}

The model was calibrated and validated over a contemporary period (19712000) to ensure an adequate representation of physical processes in the study area. I chose this period because it includes a range of wet, dry, and normal precipitation and temperature years, influenced by both positive and negative cycles of the Pacific Decadal Oscillation and El Nino and La Nina events. This period can also be represented well with the available land cover data for 1992 (US Geological Survey 1999). The model was calibrated over the first half of this period (1971-1985) and then validated for the second half of the period (1986-2000) to assess its performance. This "simple split-sample" approach is designed to guarantee that the model performs well under differing conditions (Xu and Singh 2004). The 1986-2000 period was slightly warmer and drier (mean temperature: $9.79^{\circ} \mathrm{C}$, mean precipitation: 170.6 $\mathrm{cm} /$ year) than the $1971-1985$ period (meant temperature: $9.65^{\circ} \mathrm{C}$, mean precipitation: $195.5 \mathrm{~cm} /$ year), as measured at the Three Lynx Creek station (Oregon Climate Service, 2005).

\section{Model Calibration}

The model was calibrated with two methods:

(a) Historic stream flow data was used from the station above Three Lynx Creek on the Clackamas River (USGS gage \# 14209500), which is located at the downstream extent of the study area (U.S.Geological Survey - Oregon Water Resources 2004). Flow data from this station was compared with modeled results 
to evaluate the effectiveness of runoff estimation. This was the primary method used for calibration.

(b) Historic measurements of snow water equivalent (SWE) conducted by the Oregon Snow Survey at the SNOTEL sampling sites within the study area (Clackamas Lake - elevation: $1037 \mathrm{~m}$ ) and (Peavine Ridge - elevation: $1067 \mathrm{~m}$ ) were compared to modeled predictions of SWE at their corresponding grid cell location (Clackamas Lake cell mean elevation: $1028 \mathrm{~m}$, Peavine Ridge cell mean elevation: $1042 \mathrm{~m}$ ) to evaluate the simulation of snow accumulation throughout the winter (Natural Resources Conservation Service 2004). This was used as a secondary method and not evaluated as rigorously because of the spatial and temporal variation between the modeled outputs and the SNOTEL measurements.

The calibration process required a considerable amount of time, and the model was run several hundred times with adjustments before it was determined to be optimal. On average, the model took about three hours to run through the 15-year calibration period, although it was customized to run consecutively with different parameter values for efficiency. The model parameters listed in Table 4 were used to "tune" the model during calibration.

Table 4: Tuning parameters used for calibration

\begin{tabular}{|l|l|}
\hline MODEL PARAMETER & $\begin{array}{l}\text { PROCESS AFFECTED BY TUNING OF } \\
\text { PARAMETER }\end{array}$ \\
\hline Rain-on-Snow coefficient & Rate of rain-on-snow melt \\
\hline $\begin{array}{l}\text { Pan Evaporation } \\
\text { coefficient }\end{array}$ & Rate of evapotranspiration \\
\hline Direct Runoff coefficient & Rate of direct runoff \\
\hline Indirect Runoff coefficient & Rate of indirect runoff from surplus soil moisture \\
\hline Base Flow coefficient & Rate of base flow from soil moisture \\
\hline Geology coefficient & Rates of indirect flow/ base flow based on \\
\hline
\end{tabular}




\begin{tabular}{|l|l|}
\hline & underlying geology \\
\hline $\begin{array}{l}\text { Dec/Jan direct runoff } \\
\text { multiplier }\end{array}$ & $\begin{array}{l}\text { Increased direct runoff during December and } \\
\text { January }\end{array}$ \\
\hline
\end{tabular}

In general, each parameter was tuned in isolation to find its optimal setting, although in several cases, a variable had to be revisited after the calibration of another variable changed the results. After several runs, it became apparent that the Struma River model would not be adequate to approximate the Clackamas River hydrologic processes without some modifications to its structure. This is likely due to the different characteristics of the two geographic areas where the model has been tested. The Struma River basin of Bulgaria is a larger $\left(10,797 \mathrm{~km}^{2}\right)$ and more diverse area with a drier climate; the UCB is smaller $\left(1,260 \mathrm{~km}^{2}\right)$, receives very large amounts of precipitation over a short period, is dependent on snowmelt for seasonal runoff, and contains a relatively homogeneous land cover (Chang et al., 2002).

The original model failed to record adequate flow in the UCB during the late summer months, when base flow from groundwater sustains the Clackamas River flow. To more closely approximate late summer flows, a second ground water component (base flow) was added to the model. With this modification, a proportion of surplus ground water still discharges each month as indirect flow, but a lesser proportion of soil moisture below the field capacity also discharges (base flow), contributing to total runoff from the basin. When the soil moisture is at or above Field Capacity (FC), base flow occurs at an initial proportion (13\%) of the FC of the soil. When the soil moisture falls below FC, the base flow increases relative to the soil moisture (although it decreases in absolute terms) as: 
(9) BaseFlow $=$ Soil Moist. $\times($ Initial Proport. $(\%)+(\mathrm{FC}-$ Soil Moist. $) /(\mathrm{FC} \times 10))$.

This is meant to simulate the recharge of lower level stores of ground water during the winter months (when inputs to the soil exceed the base flow proportion) and the supplementation of flows by a higher base flow during the summer, when precipitation is low and the surface soil moisture is depleted.

Indirect Runoff and Base Flow were also calibrated to reflect differences in the underlying geology of the UCB described by Ingebritsen et al. (1992) and Tague and Grant (2004). All cells were grouped as part of the Western Cascades or the High Cascades and other young basalts (see Figure 2). A geology coefficient (GC) was incorporated into the model, and during each month the indirect runoff and base flow quantities are adjusted as follows: if a cell is part of the Western Cascades then indirect runoff is increased by the GC, and base flow is decreased by the GC (see Equations 10 and 11). If a cell is part of the High Cascades or other young basalts then indirect runoff is decreased by the GC and base flow is increased by the GC: (10) IF Western Cascades THEN $\mathbb{R}=\mathbb{R} \times \mathrm{GC}$ AND BF $=\mathrm{BF} / \mathrm{GC}$;

(11) IF High Cascades THEN $\mathbb{R}=\mathbb{R} / \mathrm{GC}$ AND $B F=B F \times G C$. The large role of subsurface, permeable formations in recharging and sustaining baseflow is therefore simulated in the High Cascades, and underemphasized in the relatively impermeable Western Cascades. This modification was added at the end of the calibration process and noticeably improved results, providing a greater confidence in the distributed interpretation of the model throughout the study area.

The original model also could not adequately capture the spikes in flow that occur in the UCB during the heavy rainfalls of December and January. To more 
closely approximate these events, two additional modifications were made. First, a rain-on-snow component was added to the model. In the Pacific Northwest, rain-onsnowmelt events are often important contributors to winter flooding (Marks et al. 2001). Direct runoff that occurs over snow is assumed to run off rather than percolate into the snowpack as it is in the Struma River model. This direct runoff is also assumed to "force" the additional melting of a proportion of its volume from the snowpack. This proportion was added as a tuning variable, which is the ratio of rainforced snowmelt to direct runoff. It is important to note that while rain-forced snowmelt is greater than the direct runoff, in any month direct runoff is a lesser proportion of total precipitation because most runoff occurs indirectly through the soil with the model simulation (Figure 20 shows the mean modeled proportions of direct runoff and indirect runoff by month).

While this modification provided better results, this version of the model still consistently underestimated December and January runoff, while it overestimated April runoff. Because the soil is generally saturated during both periods, it seems likely that this increase in runoff is caused by another factor. Direct runoff is determined in a large part by the intensity of rainfall; when a large quantity of precipitation occurs over a short time, less infiltration to the soil is likely to occur. Figure 21 shows the relative intensity of monthly precipitation in the UCB as the total number of days with at least one inch of precipitation at the Three Lynx gaging station (this occurred on approximately $5 \%$ of all days) versus average monthly precipitation during the study period (1971-2000) estimated from the PRISM climate data. December and January both received the greatest amount of average monthly 
precipitation and the most days with greater than one inch $(2.54 \mathrm{~cm})$ of precipitation. However, these two months contain a larger number of high precipitation days relative to total monthly precipitation than the late winter and early spring months.

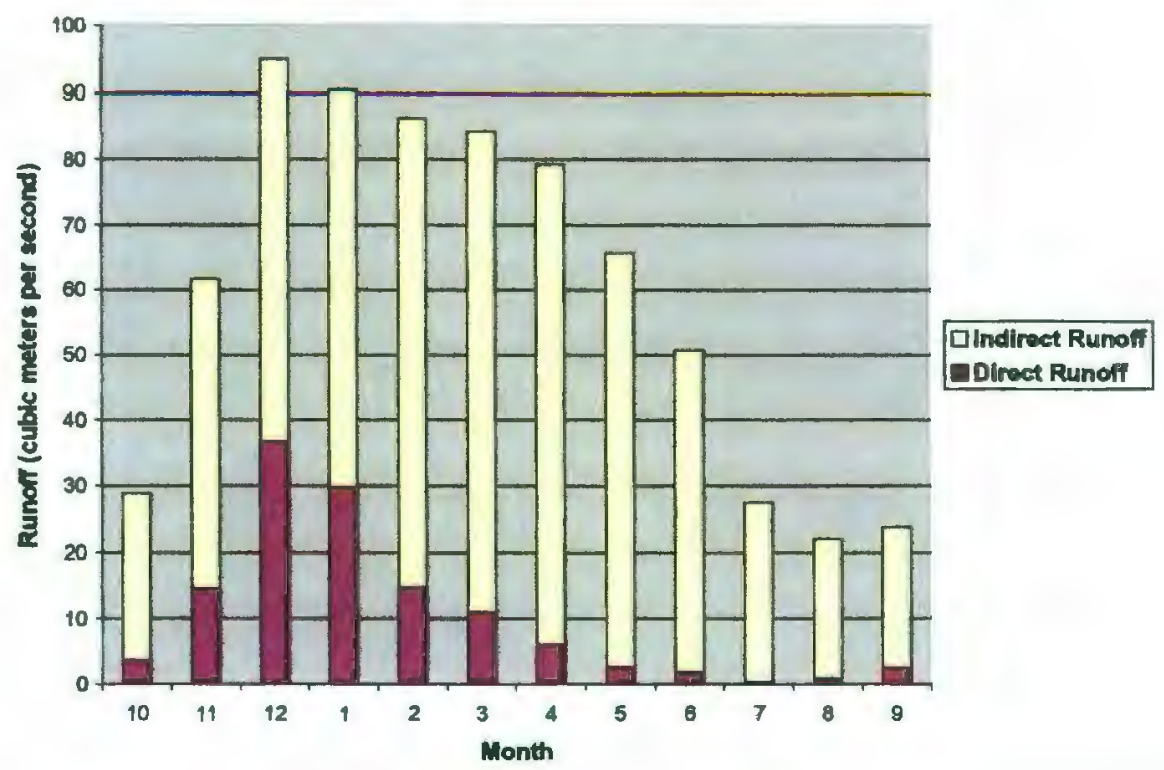

Figure 20: Comparison of mean monthly direct runoff and indirect runoff (including baseflow) as proportions of total runoff UCB as simulated in final calibrated model run (1971-1985)

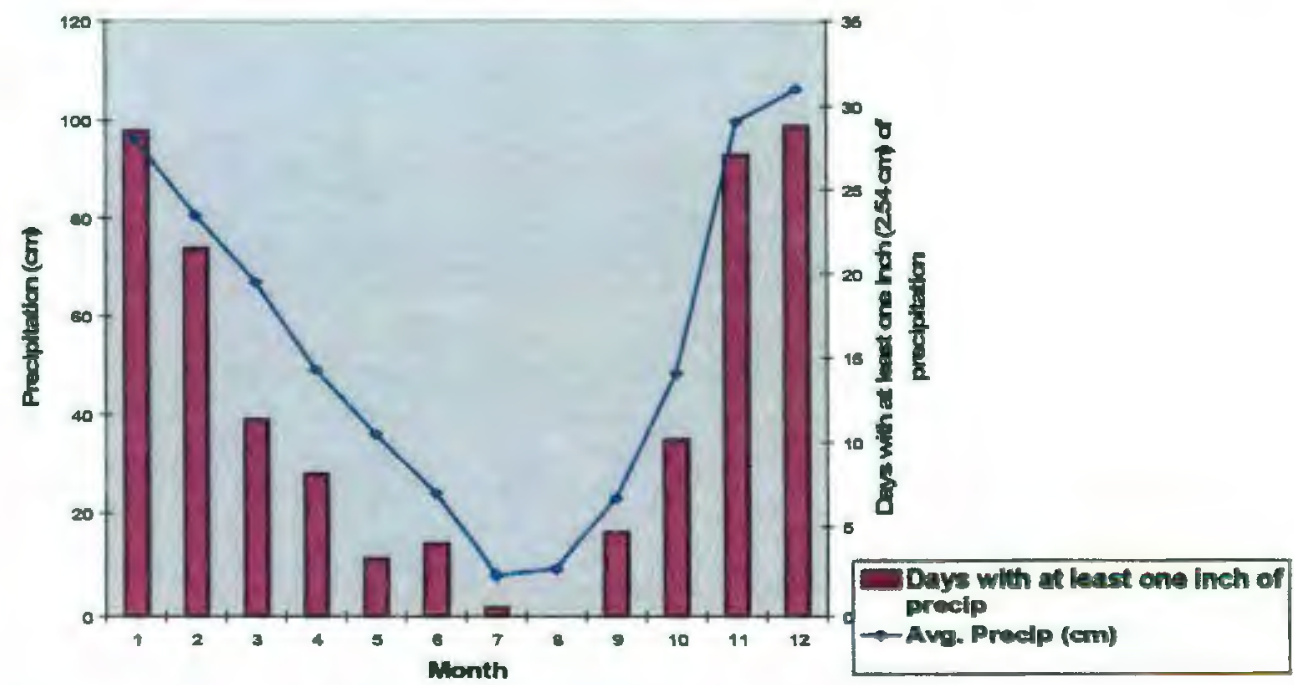

Figure 21: Monthly intensity of precipitation in the UCB (1971-2000) 
The model does not include rainfall intensity as an input parameter. Because direct runoff is generated primarily by high intensity rainfall events, it may be that the model underestimated runoff during December and January and overestimated it in the early spring (Ferguson 1996). It is also reasonable to assume that since the highest flows occur during December and January, more perennial streams may be active during this time and precipitation may enter the stream network more quickly, essentially occurring as increased direct runoff at the monthly scale. Additionally, vegetative cover is low in December and January, reducing the pore spaces in the soil where infiltration can occur and likely increasing direct runoff.

To approximate these effects at the monthly scale, a simple assumption was made that high intensity rainfall events during December and January are likely to cause a greater rate of direct runoff. A multiplier of direct runoff for these months was added as an additional tuning variable for the model. This compromises the ability of the model to approximate climate change if the monthly distribution of rainfall intensity is disrupted in the future. In other words, this addition to the model assumes that December and January rainfall will continue to occur more intensively under future climate scenarios. Table 5 shows a list of changes made to the original model.

Table 5: Modifications to the structure of the original Struma River hydrologic model

\begin{tabular}{|l|l|}
\hline Modification & Effect \\
\hline Base flow component & $\begin{array}{l}\text { Simulates contribution of lower level } \\
\text { groundwater to flow. }\end{array}$ \\
\hline Geology component & $\begin{array}{l}\text { Simulates effect of underlying geology on } \\
\text { lower level groundwater recharge and } \\
\text { contribution to base flow. }\end{array}$ \\
\hline Direct runoff over snow & $\begin{array}{l}\text { Occurs as runoff (rather than percolating } \\
\text { 7into the soil). }\end{array}$ \\
\hline Rain-on-snow melt & Additional snow melting is forced by rain. \\
\hline
\end{tabular}




\begin{tabular}{|l|l|}
\hline Dec/Jan direct runoff multiplier & $\begin{array}{l}\text { Increases direct runoff during December and } \\
\text { January to reflect intense rainfall. }\end{array}$ \\
\hline
\end{tabular}

During the calibration process, several goodness-of-fit measures were used to track the performance of the model. The Deviation of runoff volumes $\left(D_{v}\right)$ provides a simple measure of model performance and was the primary measure used. $D_{v}$ assesses the difference (\%) between actual measured flow at Three Lynx Gage (AF) and modeled flow (MF) (see Table 8 for equation). A monthly deviation $\left(\mathrm{D}_{\mathrm{vm}}\right)$ was also calculated to assess whether the model overestimated or underestimated flows throughout different parts of the water year. While these were the primary statistics used to calibrate the model performance, the Nash-Sutcliffe statistical test (described in Table 8) was also used near the completion of the calibration process to evaluate the difference in performance affected by small changes in the tuning parameters (Nash and Sutcliffe 1970). Table 6 compares the initial tuning parameter values of the Struma River model and their performance to the final calibrated values and results.

Figure 22 shows these results on a monthly hydrograph.

Table 6: Initial and final values of calibrated parameters for UCB with 1971-1985 data.

\begin{tabular}{|l|l|l|}
\hline Parameter & Value (Initial) & Value (Final) \\
\hline Legates Equation coefficient & 1.61 & 1.61 \\
\hline Degree Day melt rate coefficient & 1.0 & 1.0 \\
\hline Pan Evaporation coefficient & .75 & .67 \\
\hline Direct Runoff coefficient & 1.0 & 1.0 \\
\hline Indirect Runoff coefficient & .20 & .31 \\
\hline Rain-on-Snow coefficient & $N A$ & 3.0 \\
\hline Base Flow coefficient (initial) & $N A$ & .13 \\
\hline Geology coefficient & NA & 1.33 \\
\hline Dec/Jan direct runoff multiplier & NA & 2.2 \\
\hline Results (1971-1985) & Initial & Final \\
\hline
\end{tabular}




\begin{tabular}{|l|l|l|}
\hline Deviation of Runoff Volumes & $33.2(\%)$ & $16.0(\%)$ \\
\hline $\begin{array}{l}\text { Nash-Sutcliffe (w/ mean anmual } \\
\text { flow) }\end{array}$ & .480 & .836 \\
\hline $\begin{array}{l}\text { Nash-Sutcliffe (w/ mean monthly } \\
\text { flow) }\end{array}$ & -.035 & .673 \\
\hline
\end{tabular}

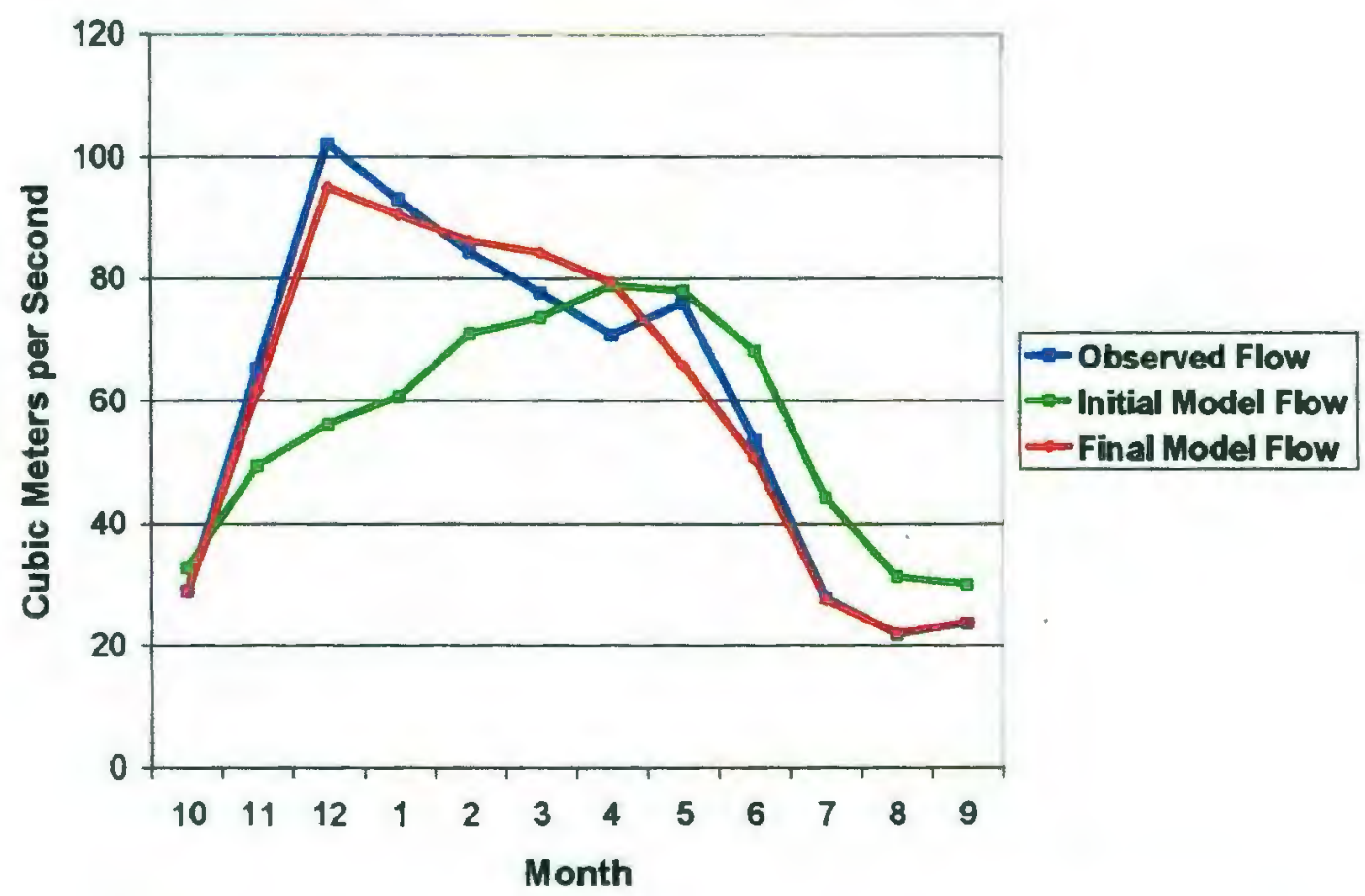

Figure 22: Mean monthly measured vs. modeled (initial and final) flows UCB (1971-1985)

A brief sensitivity analysis of the tuning parameters is helpful to show their relative effect on the model performance. Each of the tuning parameters used for model calibration were adjusted in isolation by $+10 \%,+20 \%,-10 \%$, and $-20 \%$ to determine their effect on overall monthly accuracy (Dv), as well as on net runoff during the wet (Oct-Mar) and dry (Apr-Sep) seasons. The results of this analysis are shown in Table 7. The model performance was most affected by the two parameters that control monthly flow as a proportion of available water (the Indirect Runoff 
proportion, and the Base Flow proportion). Because the period of the sensitivity analysis (1971-2000) differed from the calibration period (1971-1985), some of the adjustments to parameters actually improved the overall performance of the model over the calibrated model. For example, an increase in the geology proportion, which emphasizes base flow more in High Cascades areas, increased the model performance over the 1971-2000 period noticeably. Two other variables that increase winter snow melt and runoff (the Rain on Snow coefficient and December/January runoff multiplier) slightly improved performance when they were increased, but during the calibration phase it was shown that this improvement to runoff simulation was offset by a loss of accuracy in snowpack simulation.

Table 7: Results of Sensitivity Analysis (1971-2000)

\begin{tabular}{|r|l|l|r|r|r|}
\hline Run & Tuning Parameter & $\begin{array}{l}\text { Variation } \\
\text { (\%) }\end{array}$ & $\begin{array}{l}\text { Mean } \\
\text { Monthly } \\
\text { Dv (\%) }\end{array}$ & $\begin{array}{l}\text { Net Dv: } \\
\text { Wet Season } \\
\text { (\%) (Oct } \\
\text { Mar) }\end{array}$ & $\begin{array}{l}\text { Net Dv: Dry } \\
\text { Season (\%) } \\
\text { (Apr - Sept) }\end{array}$ \\
\hline 1 & $\begin{array}{l}\text { CALIBRATED } \\
\text { MODEL }\end{array}$ & NA & 17.0 & -0.9 & 2.0 \\
\hline 2 & RainOnSnowCof & +10 & 17.1 & -0.2 & 1.0 \\
\hline 3 & RainOnSnowCof & +20 & 17.0 & 0.1 & 0.0 \\
\hline 4 & RainOnSnowCof & -10 & 17.2 & -1.7 & 3.3 \\
\hline 5 & RainOnSnowCof & -20 & 17.4 & -2.6 & 4.6 \\
\hline 6 & PanEvapCof & +10 & 16.9 & -3.0 & 0.1 \\
\hline 7 & PanEvapCof & +20 & 17.1 & -4.9 & -1.8 \\
\hline 8 & PanEvapCof & -10 & 17.8 & 1.3 & 4.6 \\
\hline 9 & PanEvapCof & -20 & 19.2 & 3.6 & 7.3 \\
\hline 10 & IndirProp & +10 & 16.9 & 1.0 & 1.0 \\
\hline 11 & IndirProp & +20 & 17.0 & 2.0 & 0.0 \\
\hline 12 & IndirProp & -10 & 17.5 & -2.5 & 3.4 \\
\hline 13 & IndirProp & -20 & 18.6 & -4.2 & 4.9 \\
\hline 14 & BaseFlowProp & +10 & 17.8 & -0.8 & 3.4 \\
\hline 15 & BaseFlowProp & +20 & 19.4 & -0.5 & 4.8 \\
\hline 16 & BaseFlowProp & -10 & 17.2 & -1.0 & 1.1 \\
\hline 17 & BaseFlowProp & -20 & 18.0 & -1.0 & 0.2 \\
\hline 18 & DecJanMult & +10 & 17.0 & -0.4 & 1.3 \\
\hline 19 & DecJanMult & +20 & 16.9 & 0.2 & 0.4 \\
\hline & & & & \\
\hline & & & & \\
\hline
\end{tabular}




\begin{tabular}{|r|l|l|r|r|r|}
\hline 20 & DecJanMult & -10 & 17.3 & -1.5 & 3.1 \\
\hline 21 & DecJanMult & -20 & 17.5 & -2.2 & 4.1 \\
\hline 22 & GeologyProp & +10 & 16.4 & 0.0 & 0.4 \\
\hline 23 & GeologyProp & +20 & 16.0 & 1.0 & -1.8 \\
\hline 24 & GeologyProp & -10 & 17.9 & -1.7 & 3.7 \\
\hline 25 & GeologyProp & -20 & 18.5 & -2.5 & 4.9 \\
\hline
\end{tabular}

\section{Model Validation}

The final calibrated model was validated using data from the second half of the study period (1986-2000). I first tested the measured and modeled monthly results with the Kolmogorov-Smirnov Goodness-of-Fit (K-S) statistic to assess whether these data are normally distributed around their mean. The K-S statistic is commonly used for this purpose, and compares the actual cumulative frequencies of a population to the expected cumulative frequencies of a hypothetical population, in this case, a normal distribution. (McGrew and Monroe 2000). I found that both data sets have a normal distribution, with a 95\% confidence (see Table 8).

Table 8: Results of Kolmogorov-Smirnov test for normal data distribution

\begin{tabular}{|l|l|l|}
\hline Data Set & K-S Z-score & Significance \\
\hline $\begin{array}{l}\text { Actual Monthly Flow Data } \\
\text { (1986-2000) }\end{array}$ & 1.623 & 0.01 \\
\hline $\begin{array}{l}\text { Modeled Monthly Flow Data } \\
\text { (1986-2000) }\end{array}$ & 1.352 & 0.05 \\
\hline
\end{tabular}

Because these data are normally distributed, it is possible to use parametric statistical tests on the sample data sets for the validation process. Multiple statistical tests were used to provide a higher degree of confidence in the validation process; no one test is perfect for hydrologic assessments (ASCE Task Committee 1993; Legates and McCabe Jr. 1999). The calibrated model was run once for the 1986-2000 period, and based on this only one change was made to the calibrated model: the pan 
evaporation coefficient was adjusted from 0.64 to 0.67 to achieve a balance between the (1971-1985) and (1986-2000) data and provide slightly better results for the entire period (1971-2000). The model was then re-run and validated for the 1986-2000 results. Table 9 shows a summary of the statistical tests and results used for this validation process.

Table 9: Statistical tests used for validation of model with 1986-2000 data

\begin{tabular}{|c|c|c|c|}
\hline Statistical Test & Equation & Description & $\begin{array}{l}\text { Result } \\
(1986 \\
2000)\end{array}$ \\
\hline $\begin{array}{l}\text { Mean Absolute } \\
\text { Error (MAE) }\end{array}$ & $\mathrm{MAE}=\Sigma|\mathrm{AF}-\mathrm{MF}| / \mathrm{n}$ & $\begin{array}{l}\text { Absolute measure of } \\
\text { model error in cubic } \\
\text { meters per second }\end{array}$ & $\begin{array}{l}10.08 \\
(\mathrm{cms})\end{array}$ \\
\hline $\begin{array}{l}\text { Deviation of } \\
\text { Runoff Volumes } \\
\left(D_{v}\right)\end{array}$ & $\mathrm{Dv}=\left(\sum|(\mathrm{AF}-\mathrm{MF}) / \mathrm{AF}|\right) / \mathrm{n}$ & $\begin{array}{l}\text { Average difference (\%) } \\
\text { between measured and } \\
\text { model flows }\end{array}$ & $\begin{array}{l}18.0 \\
(\%)\end{array}$ \\
\hline $\begin{array}{l}\text { Pearson's } \\
\text { Coefficient of } \\
\text { Determination }\left(\mathrm{R}^{2}\right)\end{array}$ & $R=\frac{(\Sigma(A F-A v)(M F-M A v)}{\left(\Sigma(A F-A v)^{2}\right)^{0.5}\left(\Sigma(M F-M A v)^{2}\right)^{0.5}}$ & $\begin{array}{l}\text { Standardized measure of } \\
\text { model performance based } \\
\text { on observed and predicted } \\
\text { annual means }(-1 \text { to }+1)\end{array}$ & .917 \\
\hline $\begin{array}{l}\text { Nash-Sutcliffe } \\
\text { Coefficient of } \\
\text { Efficiency w/ mean } \\
\text { annual value (NS) }\end{array}$ & $\mathrm{NS}=1-\frac{\sum(\mathrm{AF}-\mathrm{MF})^{2}}{\sum(\mathrm{AF}-\mathrm{Av})^{2}}$ & $\begin{array}{l}\text { Standardized measure of } \\
\text { model performance } \\
\text { against observed annual } \\
\text { mean }(-\infty \text { to }+1)\end{array}$ & .838 \\
\hline $\begin{array}{l}\text { Nash-Sutcliffe } \\
\text { Coefficient of } \\
\text { Efficiency w/ mean } \\
\text { monthly values } \\
(\mathrm{NSm})\end{array}$ & $\mathrm{NSm}=1-\frac{\sum(\mathrm{AF}-\mathrm{MF})^{2}}{\sum(\mathrm{AF}-\mathrm{Avm})^{2}}$ & $\begin{array}{l}\text { Standardized measure of } \\
\text { model performance } \\
\text { against observed monthly } \\
\text { means }(-\infty \text { to }+1)\end{array}$ & .652 \\
\hline
\end{tabular}

$(\mathrm{MF}=$ Modeled Flow, $\mathrm{AF}=$ Actual Observed Flow, $\mathrm{Av}=$ Average Observed Flow, Avm $=$ Average Monthly Observed Flow, MAv $=$ Average Modeled Flow, $n=\#$ of months)

MAE is an absolute measure of model error, $D_{v}$ is a simple but effective evaluation of the deviation between the measured and modeled flows, and the other statistical tests $\left(\mathrm{R}^{2}, \mathrm{NS}\right.$, and NSm) are relative goodness-of-fit measures of model performance that estimate the proportion of total variation in the observed data that can be explained with the model. The latter three tests correlate the actual and 
modeled results to produce a statistic; a value of 0 indicates that the model explains variation no better than a mean observed average, while higher values (up to 1.0) indicate a better correlation between the mean and observed flow data. $\mathbf{R}^{2}$ is commonly used for many types of analysis but is not sensitive to differences in the observed and model means and variances; NS is frequently used for hydrologic analysis but can be overly sensitive to outliers (Legates and McCabe Jr. 1999). NSm provides a more accurate analysis of the seasonal performance of the model performance because it evaluates the model results with monthly mean averages rather than an annual average. Figures 23 and 24 show the monthly performance of the model using the $\mathrm{D}_{v}$ statistic for the mean monthly averages, and each individual month, respectively.

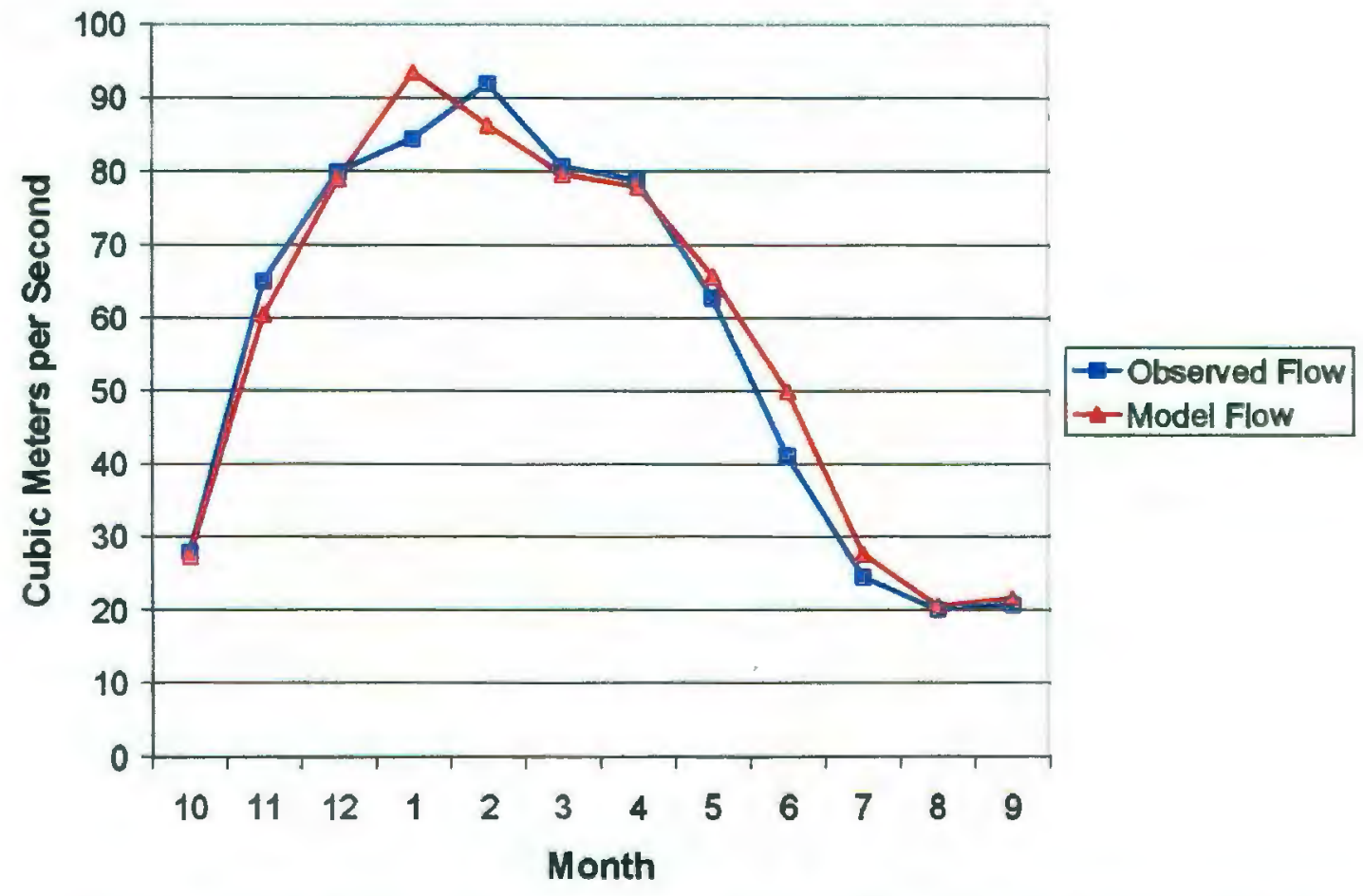

Figure 23: Mean monthly comparison of observed and modeled flows (1986-2000) 


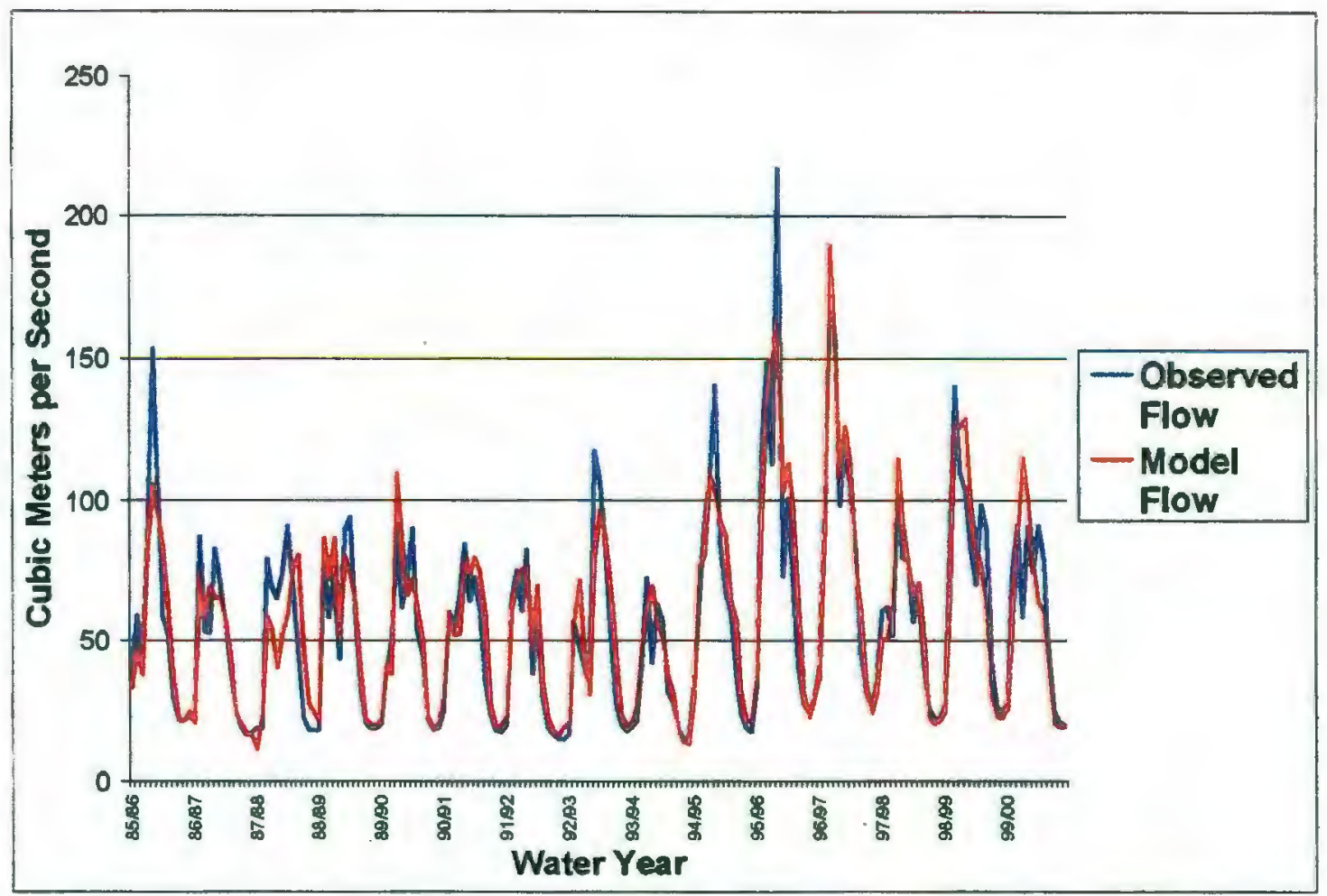

Figure 24: Monthly comparison of observed and modeled flows (1986-2000)

The model performs well during most periods of the year, but overestimates runoff during the months of June $(+21.5 \%)$, July $(+12.8 \%)$, and January $(+10.8 \%)$, and underestimates runoff during November $(-7.0 \%)$ and February $(-6.2 \%)$. Several of the largest errors (six of the 20 highest values for $D_{v}$ out of 180 months) occurred during the 1987/88 water year. An examination of the daily precipitation and runoff data from this year shows that a large storm event occurred in December, which was not captured well with the monthly data. Following a period of cool weather and precipitation that presumably contributed to snow accumulation in the upper basin, a warm and wet storm event occurred on December 10 , leading to peak flow $(21,300$ cfs) that ranks with the highest historical flows recorded at Three Lynx Gage. It seems likely that much of the runoff was created by rain-on-snow melting. The model 
does not capture the enormity of this event, and subsequent simulations for the months of 1988 are significantly off as a result (a poor match with the 87/88 SNOTEL data also supports this). This case illustrates the limitations in modeling hydrologic behavior of a basin heavily influenced by snowmelt at the monthly scale, which often cannot catch extreme events that may affect the hydrograph for several months.

Despite this event, the model performed fairly well at recreating flows from the basin over the validation period; the model explains between $84 \%$ and $92 \%$ of the variability in the observed data when compared to an annual flow average and $65 \%$ of the variability in the observed data when compared to monthly flow averages. These measures compare favorably with the results from other hydrologic models (ASCE Task Committee 1993; Legates and McCabe Jr. 1999; Knight et al. 2001). Ideally, separate validations would be enlisted to evaluate the performance of the model in each of the subwatersheds of the study area and for each of the various model components, but the lack of available flow data make this infeasible.

SNOTEL data were used as a secondary validation method specifically for the snow accumulation and melt components of the model. Unlike the flow data, which is easily evaluated at a monthly scale for the entire area, SNOTEL measurements are not directly comparable to the modeled results because they are taken at certain points in space and time. Data from two SNOTEL sites (Clackamas Lake and Peavine Ridge) were compared to the modeled results for the cell where these sites exist, but the SNOTEL locations are not necessarily representative of the entire cell. A daily SNOTEL measurement was taken at the end of the month to compare to the modeled end-of-the-month results, but this also introduced uncertainty because weather events 
can easily change snow measurements from day to day. Given the spatial and temporal uncertainty in comparing SNOTEL measurements to monthly model predictions, this process was not as rigorously validated as the flow data but instead "eyeballed" during both the calibration and validation processes to judge the general performance of the model to predict snow accumulation and melt.

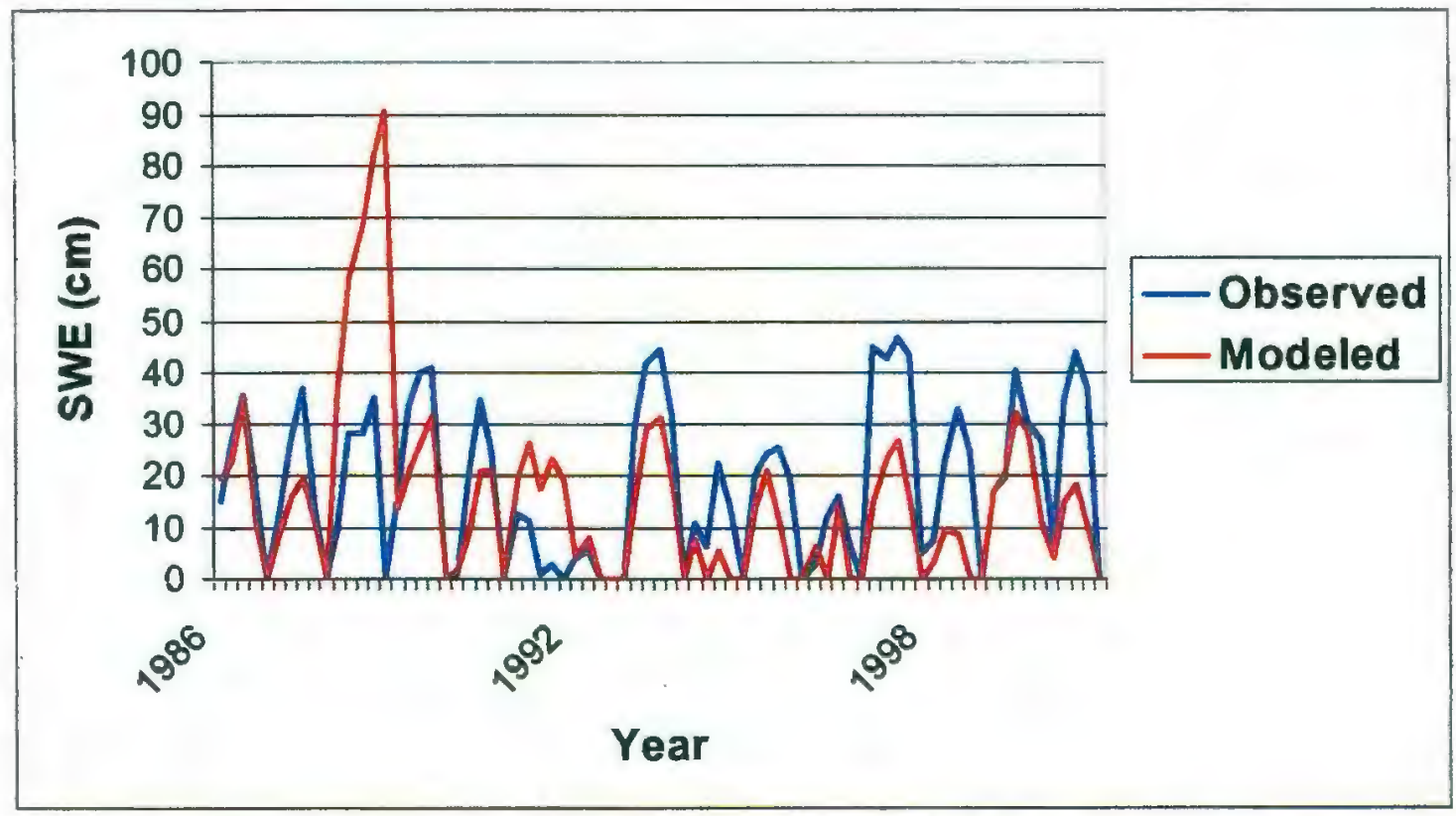

Figure 25: Comparison of actual and modeled SWE at Clackamas Lake SNOTEL site (1986-2000). For each year, five data points represent snow water equivalent on the following dates: $1 / 1,2 / 1,3 / 1,4 / 1$, and $5 / 1$. The measured samples depict SWE at a specific point (Clackamas Lake SNOTEL elevation: $1037 \mathrm{~m}$ ) while the modeled samples depict mean SWE in the $1 \mathrm{~km}$ cell that contains the SNOTEL site, (mean elevation: $1028 \mathrm{~m}$ ) 


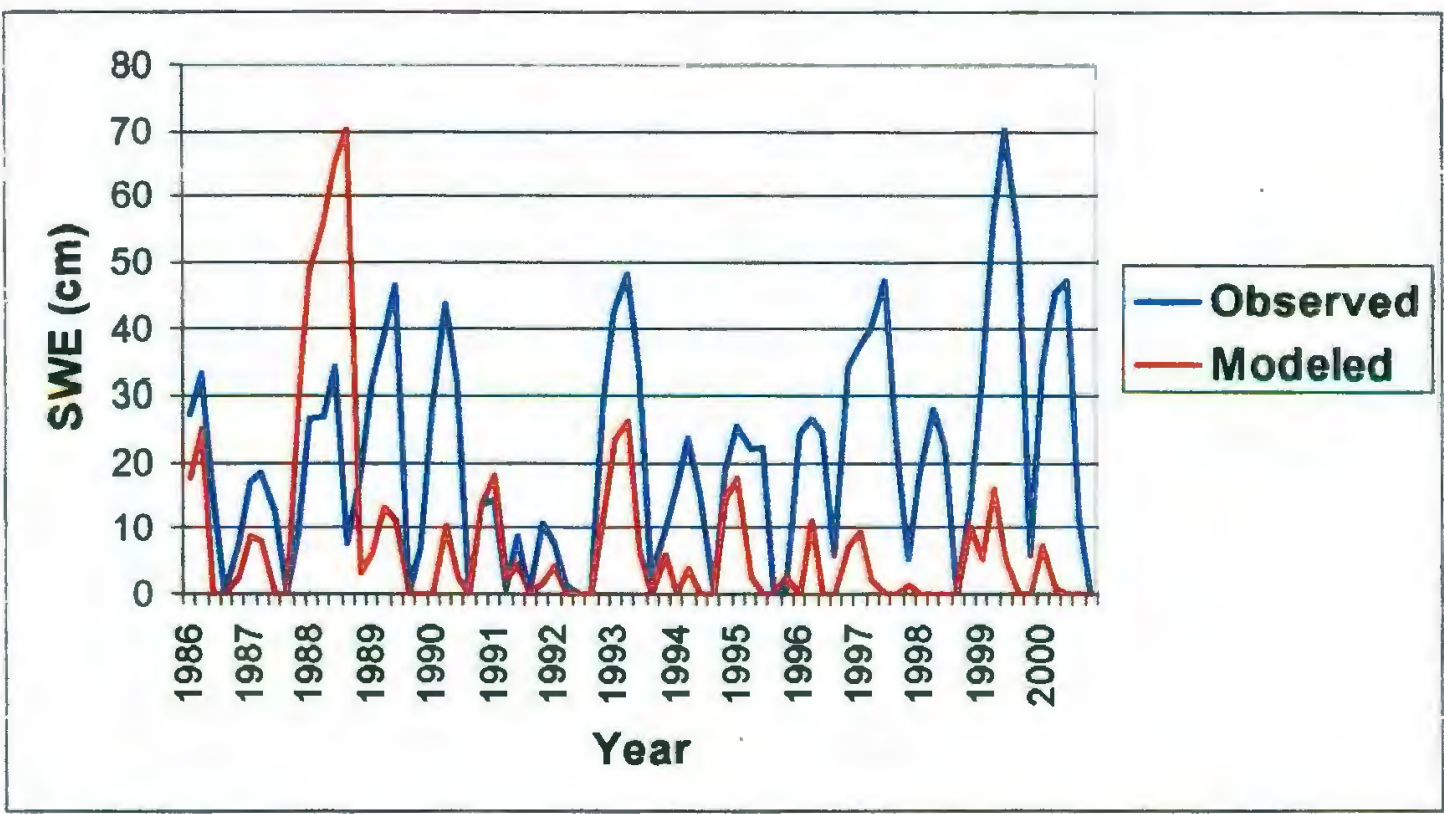

Figure 26: Comparison of actual and modeled SWE at Peavine Ridge SNOTEL site (1986-2000). For each year, five data points represent snow water equivalent on the following dates: $1 / 1,2 / 1,3 / 1,4 / 1$, and $5 / 1$. The measured samples depict SWE at a specific point (Peavine Ridge SNOTEL, elevation: $1067 \mathrm{~m}$ ) while the modeled samples depict mean SWE in the $1 \mathrm{~km}$ cell that contains the SNOTEL site, (mean elevation: $1042 \mathrm{~m}$ )

Figures 25 and 26 compare the actual and modeled SWE at the SNOTEL sites.

On average, the model overestimates snow accumulation at the Clackamas Lake site $\left(D_{v}=+17.2 \%\right)$ although it actually underestimates it in more months (55) than it overestimates it (9), and it substantially underestimates snow accumulation at the Peavine Ridge site $\left(D_{v}=-44.9 \%\right)$. The model thus appears to perform poorly at capturing the snow water equivalent of the two cells where SNOTEL sites exist. The accumulation and depreciation of the snowpack in the model data does generally follow the monthly trends in the measured data, suggesting that the timing of snow accumulation and melt are captured in the simulation, but the actual quantity of sniow is not captured well. Attempts to calibrate the model to more closely resemble snow 
measurements at these two points resulted in gross errors in flow data. A decision was therefore made to largely calibrate the model according to runoff, which represents the entire study area, rather than snow measurements at two points.

Figure 27 shows the average distribution of precipitation, evapotranspiration, and runoff from the study area for two months (January and July) during the 19862000 period. The lag in runoff from high elevation areas dependent on snowmelt is apparent in these maps, as is the contribution of summer base flow from areas with High Cascades geology (primarily to the east). 


\section{Precipitation}
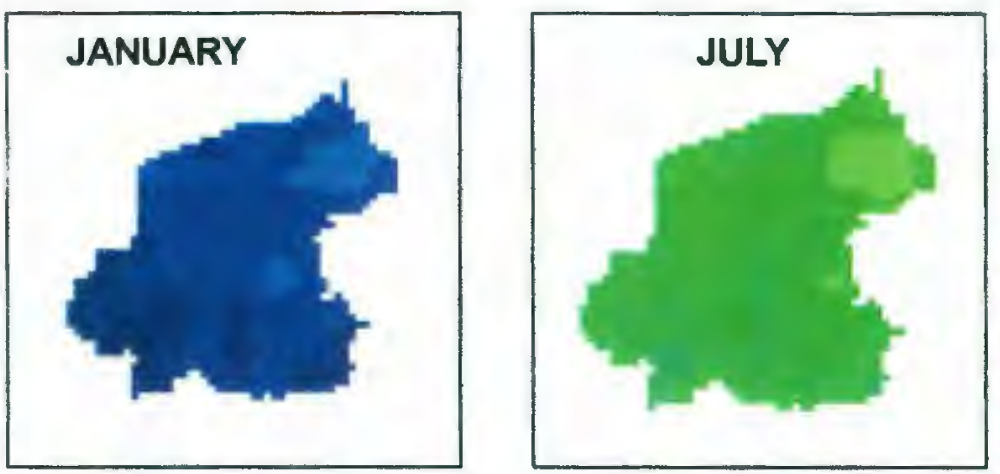

Scale (cm)

$0-0.5$

$0.5-1.0$

$1.0-1.5$

$1.5-2.0$

$2.0-3.0$

$3.0-4.0$

$4.0 \div 6.0$

$6.0-10$

Evapotranspiration
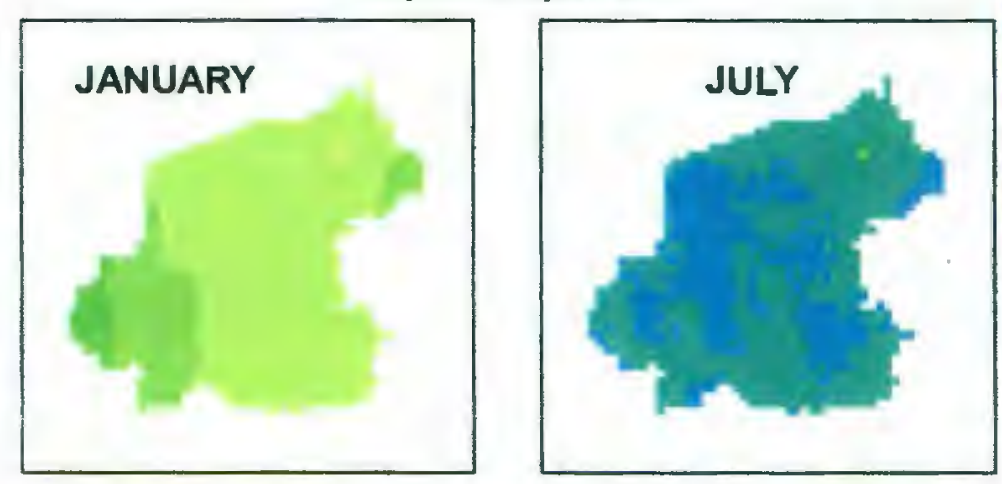

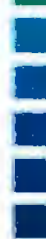
$10-16$

$16-24$

$24-32$

$32-40$

$40-48$

\section{Runoff}
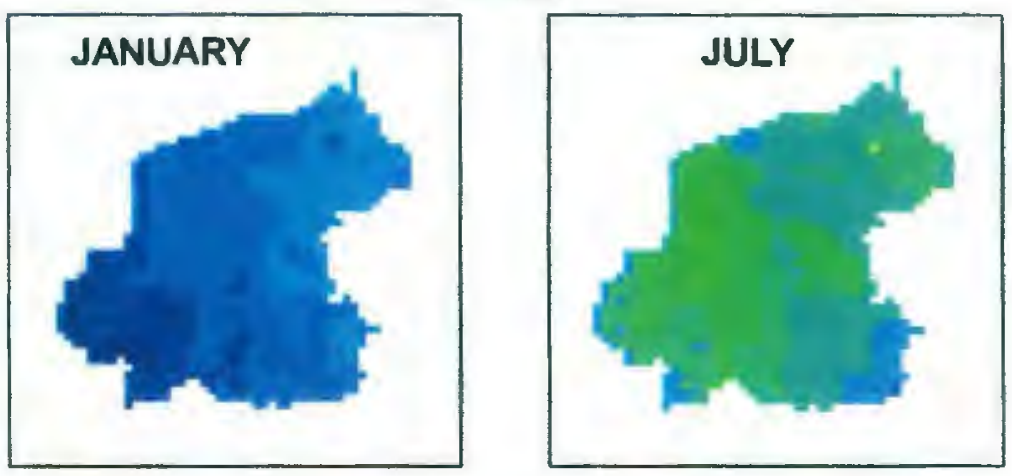

Figure 27: Mean monthly model outputs, 1986-2000, UCB

Based on the validation process, I determined that the model is able to approximate the hydrologic regime of the UCB at a monthly scale, and it was used for the climate assessment proposed in this thesis. 


\section{MODEL APPLICATION FOR CLIMATE CHANGE SCENARIOS}

The Western United States has experienced a pattern of warmer temperatures during the latter $20^{\text {th }}$ century. This trend is apparent in actual climate measurements, and also in related environmental conditions. Cayan et al. (2001) found that in high elevation areas of the Western United States, the timing of the first bloom of spring plants (lilac and honeysuckle) and of the first major pulse of snowmelt have both been trending to occur at an earlier spring date since the mid-1970s. Regonda et al. (2005) and Stewart et al. (2005) confirmed this trend of earlier runoff throughout the western U.S. In the Pacific Northwest, an analysis of 113 Historical Climate Network stations showed that temperatures have raised an average of $0.82^{\circ} \mathrm{C}$ during the $20^{\text {th }}$ century (Mote et al. 2003). This warming trend has been closely correlated to an anthropogenic increase of atmospheric greenhouse gases (Schneider 1997, IPPC 2001).

The model was run for two hypothetical future climate periods to assess the impacts of future climate change from a continued increase in atmospheric greenhouse gases from anthropogenic sources. I used the outputs from the two global climate models of the IS92 group, the Hadley Circulation Model (HadCM2) and the Canadian Centre for Climate Modeling and Analysis model (CGCM1) to estimate the potential consequences of climate change (Johns et al. 1997; Flato et al. 2000). While macroscale hydrologic models for large basins are often coupled with Global Climate Models (GCMs), assessments for smaller basins generally use climatic outputs from GCMs, which may be downscaled to the scale of the study (Xu and Singh 2004). 
GCMs simulate future changes to climate that will result from the anthropogenic increases of greenhouse gases, describing these changes in the form of quantitative increases or decreases to climatic variables such as temperature and precipitation from a contemporary baseline period. These simulations are coupled, each joining a three-dimensional climate model with a modular ocean model. They perform a global simulation at a coarse scale ( 3.75 longitude $\times 2.5$ latitude $(\mathrm{HadCM} 2)$ and 3.75 longitude $\times 3.75$ latitude $(\mathrm{CCC})$ ). The forcing effect of increasing greenhouse gases on climate is simulated over a continuous historic and future period (Hadley model: 1860-2100, CCC model: 1900-2100), and these simulations are validated against the historic record (Johns et al. 1997; Flato et al. 2000). The GCM simulations used in this study were chosen because they were used for the U.S. National Climate Assessment (USGCRP 2000). They assume an effective greenhouse gas forcing change corresponding to a compounded increase of $\mathrm{CO}_{2}$ at a rate of $1 \%$ per year and the reflection of incoming radiation by increased sulphate aerosols (Johns et al. 1997; Flato et al. 2000). These assumptions are derived from middle-of-the-road projections of $21^{\text {st }}$ century population growth and fossil fuel use (IPPC 2001).

The calibrated hydrologic model (described in Chapters IV and V) was run for two periods, $2010-2039$ (referred to as the 2020s in the GCM data and hereafter in this document because it projects approximate climate during this decade) and 2070-2099 (referred to as the 2080s hereafter in this document). Two GCMs, the CCC and Hadley simulations are used in the assessment, producing four scenarios: CCC 2020s and 2080s, and Hadley 2020 s and 2080s. The mean monthly estimates of climate change in these GCM scenarios were used to adjust the monthly temperature and 
precipitation values of the thirty-year baseline period (1971-2000) and estimate the effects of future climate change over a variable period. The hydrologic model therefore assesses the implications of forecasts of climate change around two future periods based on commonly accepted predictions of greenhouse gas increases and their effects on global and local climate.

I downloaded the temperature and precipitation change data for each of the climate scenarios from the IPPC Data Distribution Centre (2005) and extracted the values for the grid cells that surround the UCB. Figure 28 shows the location of the GCM grid cell centers relative to the UCB study area. These grid cells are coarse, and no one cell represents the UCB well, so I interpolated the change values of the nearby cells (Hadley: six cells, CCC: four cells) for each month with a kriging method in ArcGIS software to a $1 / 2$ degree cell resolution and then calculated the mean values for the UCB with a zonal statistics function. The kriging method develops a prediction map based on the values of the nearby cells and is useful for downscaling data when spatial autocorrelation between nearby locations exists. Table 10 shows the change values for each month of each climate scenario based on this analysis. 


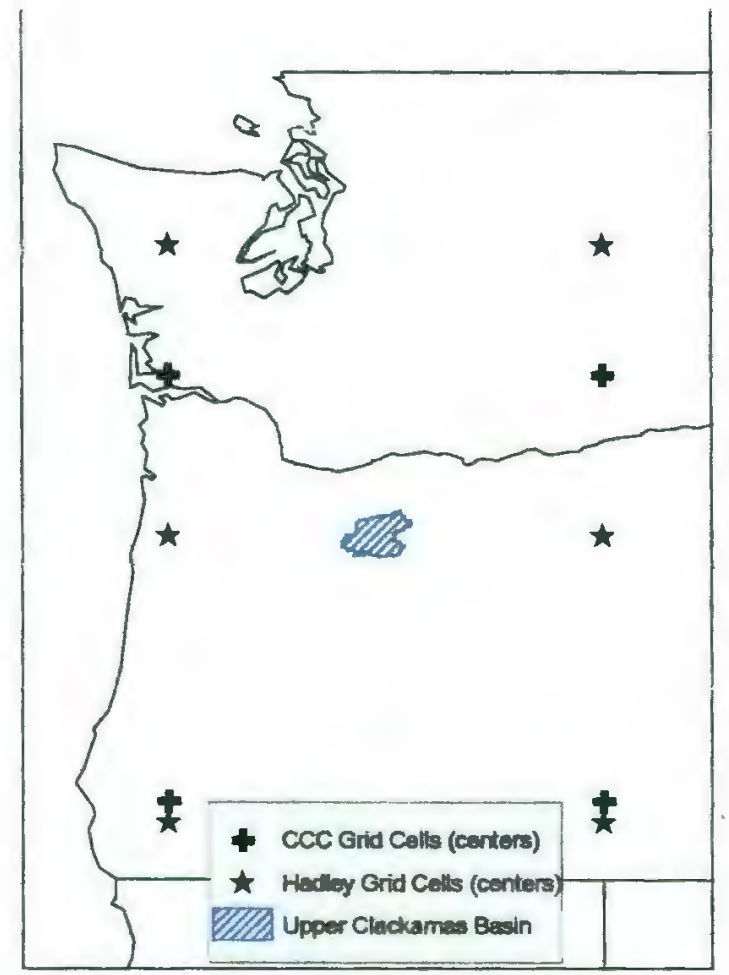

Figure 28: Relative location of UCB and neighboring global climate model grid cells

Table 10: Changes to mean monthly temperatures of the UCB from the Hadley and Canadian Global Climate Models

\begin{tabular}{|c|c|c|c|c|c|c|c|c|}
\hline $\begin{array}{l}\text { GCM } \\
\text { Month }\end{array}$ & $\begin{array}{l}\text { Had } \\
2025 \\
\text { precip } \\
(\%)\end{array}$ & $\begin{array}{l}\text { CCC } \\
2025 \\
\text { precip } \\
(\%)\end{array}$ & $\begin{array}{l}\text { Had } \\
2085 \\
\text { precip } \\
(\%)\end{array}$ & $\begin{array}{l}\text { CCC } \\
2085 \\
\text { precip } \\
(\%)\end{array}$ & $\begin{array}{l}\text { Had } \\
2025 \\
\text { temp } \\
\text { (C) }\end{array}$ & $\begin{array}{l}\text { CCC } \\
2025 \\
\text { temp } \\
\text { ( C) }\end{array}$ & $\begin{array}{l}\text { Had } \\
2085 \\
\text { temp } \\
\text { ( C) }\end{array}$ & $\begin{array}{l}\text { CCC } \\
2085 \\
\text { temp } \\
\text { ( C) }\end{array}$ \\
\hline Jan & -0.49 & +6.27 & +11.40 & +46.70 & +1.57 & +1.38 & +3.55 & +3.96 \\
\hline Feb & +6.54 & +12.66 & +13.77 & +50.43 & +1.63 & +1.34 & +3.50 & +4.12 \\
\hline Mar & -3.75 & +8.78 & +1.61 & +28.86 & +1.44 & +1.56 & +2.97 & +3.73 \\
\hline Apr & -1.65 & -11.22 & +1.32 & -9.16 & +1.20 & +1.35 & +2.89 & +3.46 \\
\hline May & +7.30 & -22.46 & +21.90 & -9.47 & +0.84 & +1.56 & +2.10 & +3.83 \\
\hline Jun & +14.54 & -4.73 & +9.45 & +15.23 & +1.33 & +1.27 & +3.26 & +4.25 \\
\hline Jul & -7.10 & -1.86 & -4.73 & +4.34 & +1.40 & +1.16 & +3.84 & +3.32 \\
\hline Aug & +19.83 & +0.00 & +2.48 & +12.13 & +1.23 & +0.96 & +4.52 & +2.99 \\
\hline Sep & +2.91 & +0.85 & +6.79 & +20.50 & +1.68 & +1.32 & +4.26 & +3.81 \\
\hline Oct & +24.71 & -2.17 & +55.00 & +25.82 & +0.87 & +1.16 & +2.38 & +3.97 \\
\hline Nov & +12.91 & +11.03 & +10.91 & +31.66 & +1.14 & +1.14 & +2.79 & +3.42 \\
\hline Dec & +2.71 & +24.37 & +9.40 & +46.04 & +1.53 & +1.43 & +3.59 & +3.31 \\
\hline Yearly & +5.33 & +5.51 & +12.41 & +27.13 & +1.32 & +1.30 & +3.30 & +3.68 \\
\hline
\end{tabular}


Based on this analysis, the GCMs forecast that mean annual temperatures in the UCB will increase by about $1.3^{\circ} \mathrm{C}$ by the 2020 s and approximately $3.5^{\circ} \mathrm{C}$ by the 2080s. In the 2080s scenarios, the Hadley GCM estimates that warming will be considerably higher during the summer months and relatively lower during the spring, while the Canadian GCM estimates that warming will be more evenly distributed throughout the year. Warmer temperatures are important for the hydrologic cycle because they affect snow accumulation and melt, and also the rate of evapotranspiration. The GCMs agree that mean annual precipitation will increase by approximately $5.4 \%$ by the 2020 s period. However, they differ in their forecasts of precipitation increases by the 2080 s period; the Hadley model shows moderate annual increases $(+12.4 \%$ by the 2080 s) while the CCC model shows large annual increases $(+27.1 \%$ by the 2080 s). The GCMs are in agreement that these 2080 s precipitation increases will largely occur during the fall and winter months, with smaller increases or decreases of precipitation to occur during the spring and summer months. Globally, precipitation may be expected to increase with rising temperatures because this will provide more energy for evaporation, but this may vary widely locally. The distribution of increases in precipitation and evapotranspiration will likely drive local increases and decreases in river flows (Arnell 2003).

Because the GCMs use a baseline period of 1961-1990 and this study uses a baseline period of 1971-2000, I calculated the difference between mean temperature and precipitation at the Three Lynx weather stage between these two periods and used these differences to adjust the GCM change values for the climate scenario runs of the 
hydrologic model. Equations 12 and 13 were added to the hydrologic model to adjust the monthly average temperatures based on the GCM and 1961 to 1990 adjustments:

$$
\text { Climate Scenario Temp }=\text { TempC }- \text { TempCh1 }+ \text { TempCh2, }
$$

where:

TempC = Contemporary (1971-2000) temperature used in hydrologic model;

TempCh1 = Absolute difference in observed temperature at Three Lynx station; between 1971-2000 period and 1961-2000 period;

TempCh2 = Absolute difference in temperature between climate scenario and 19611990 baseline period, as given by GCM, and

$$
\text { Climate Scenario Precip }=Y+(\operatorname{PrecipCh} 2 * Y) \text {, }
$$

where:

$\mathrm{X}=1 /(1+$ PrecipCh1);

$\mathrm{Y}=$ PrecipC $* \mathrm{X}$

PrecipC $=$ Contemporary (1971-2000) precipitation;

PrecipCh1 $=$ Relative difference (\%) in observed precipitation at Three Lynx station between 1961-1990 period and 1971-2000 period;

PrecipCh2 = Relative difference (\%) in precipitation between 1961-1990 period and climate scenario, as given by GCM.

The final validated hydrologic model was not changed aside from these adjustments to monthly temperature and precipitation, and was run for the four climate scenarios (Hadley 2020s and 2080s, CCC 2020s and 2080s). The validated model was also run continuously for the entire baseline period (1971-2000) for comparison with the outputs from the climate scenarios. 


\section{RESULTS AND DISCUSSION}

\section{Annual Effects of Climate Change}

The Hydrologic model estimates that annual evapotranspiration in the UCB will show moderate increases by the 2020 s and large increases by the 2080 s (see Table 11). The scenarios differ considerably by the 2080 s: Under the Hadley scenario, increased evapotranspiration negates all precipitation increases and annual runoff volumes are unchanged from the 1971-2000 baseline period; under the CCC scenario, a large increase in precipitation compensates for increased evapotranspiration, and annual runoff volumes are $20.8 \%$ higher than during the baseline period. In both scenarios, the proportion of precipitation falling as snow decreases significantly between the baseline period (26.5\%) and the 2080s (CCC: $14.0 \%$, Hadley: $14.1 \%$ ).

Table 11: Annual UCB precipitation and modeled outputs of five climate scenarios

\begin{tabular}{|l|l|l|l|l|l|}
\hline $\begin{array}{l}\text { Model } \\
\text { Climate } \\
\text { Scenario }\end{array}$ & $\begin{array}{l}\text { Average } \\
\text { Annual } \\
\text { Precipitation } \\
(\mathbf{c m})\end{array}$ & $\begin{array}{l}\text { Average } \\
\text { Annual } \\
\text { Rainfall } \\
(\mathbf{c m})\end{array}$ & $\begin{array}{l}\text { Average } \\
\text { Annual } \\
\text { Snowfall } \\
(\mathbf{c m})\end{array}$ & $\begin{array}{l}\text { Average Annual } \\
\text { Evapotranspiration } \\
(\mathbf{c m})\end{array}$ & $\begin{array}{l}\text { Average } \\
\text { Annual } \\
\text { Runoff (cm) }\end{array}$ \\
\hline $\begin{array}{l}\text { Baseline } \\
(1971- \\
2000)\end{array}$ & 194.8 & 143.2 & 51.6 & 46.0 & 148.5 \\
\hline $\begin{array}{l}\text { CCC } \\
2020 \text { s }\end{array}$ & 207.9 & 160.6 & 47.3 & 54.2 & 153.5 \\
\hline $\begin{array}{l}\text { Hadley } \\
2020 \mathrm{~s}\end{array}$ & 205.4 & 162.2 & 43.2 & 55.2 & 150.0 \\
\hline $\begin{array}{l}\text { CCC } \\
2080 \mathrm{~s}\end{array}$ & 255.3 & 219.5 & 35.8 & 75.6 & 179.4 \\
\hline $\begin{array}{l}\text { Hadley } \\
2080 \mathrm{~s}\end{array}$ & 218.9 & 188 & 30.9 & 70.1 & 148.5 \\
\hline
\end{tabular}

Monthly Seasonal Changes to Flow

Figures 29 and 30 show mean monthly flows under each of the five climate scenarios. During the 2020 s, in both scenarios mean flows remain largely unchanged 
from the baseline period during October and November, but are greater during the winter months and reduced during the rest of the hydrologic year. These trends are more pronounced in the CCC simulation than the Hadley simulation, where both mean January increases from baseline are greater $(+16.4 \%$ vs. $+9.8 \%)$ and mean July decreases from baseline are greater $(-16.3 \%$ vs. $-15.3 \%)$ than in the Hadley simulation. These trends are simulated to continue in the 2080s, with larger increases to baseline winter flows and larger decreases to baseline summer flows than the 2020 s simulation. The 2080s CCC simulation shows larger increases to baseline winter flow than the Hadley simulation ( $48.7 \%$ vs. $+15.9 \%$ for January) but smaller reductions to baseline summer flow ( $-17.8 \%$ vs. $-24.7 \%$ for July), demonstrating the sensitivity of the hydrologic model to the larger precipitation inputs from the CCC 2080s data.

Interestingly, the month of peak runoff (January) remains unchanged in all of the climate scenarios. This seems to contradict the observed trends of earlier runoff that have been recorded during the $20^{\text {th }}$ century throughout the western U.S. (Regonda et al. 2005; Stewart et al. 2005). However, the peak in monthly runoff (January) is different than spring onset melting peaks, which are established in these research studies but is not adequately captured in the monthly data used in this study. Between January and May, all future climate scenarios show the peak runoff falling off more rapidly than during the baseline period, and this decline could be assessed with and would likely correspond with earlier peak spring flows if the model operated at a finer temporal scale. 


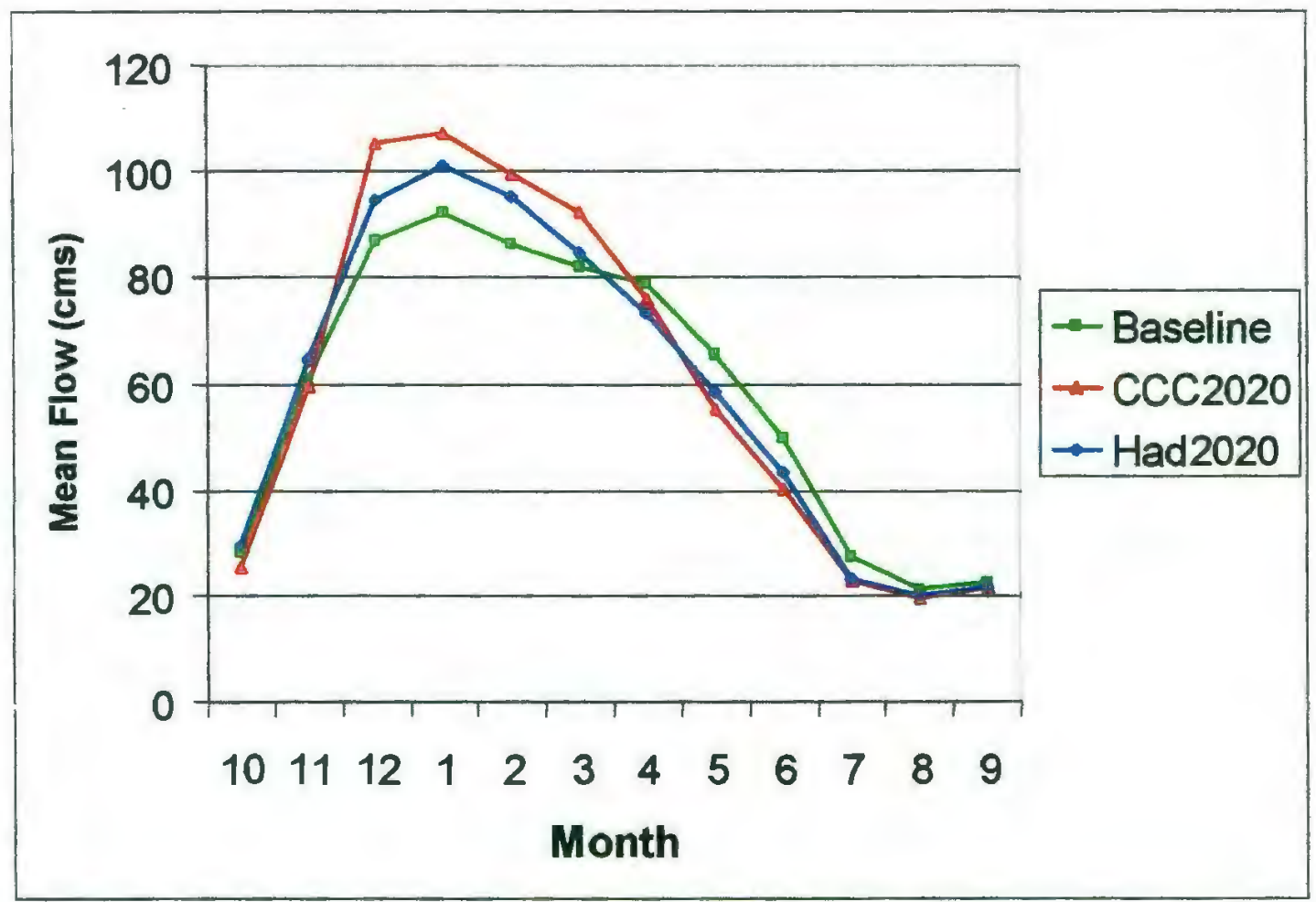

Figure 29: UCB mean monthly modeled flows of baseline (1971-2000) and 2020s

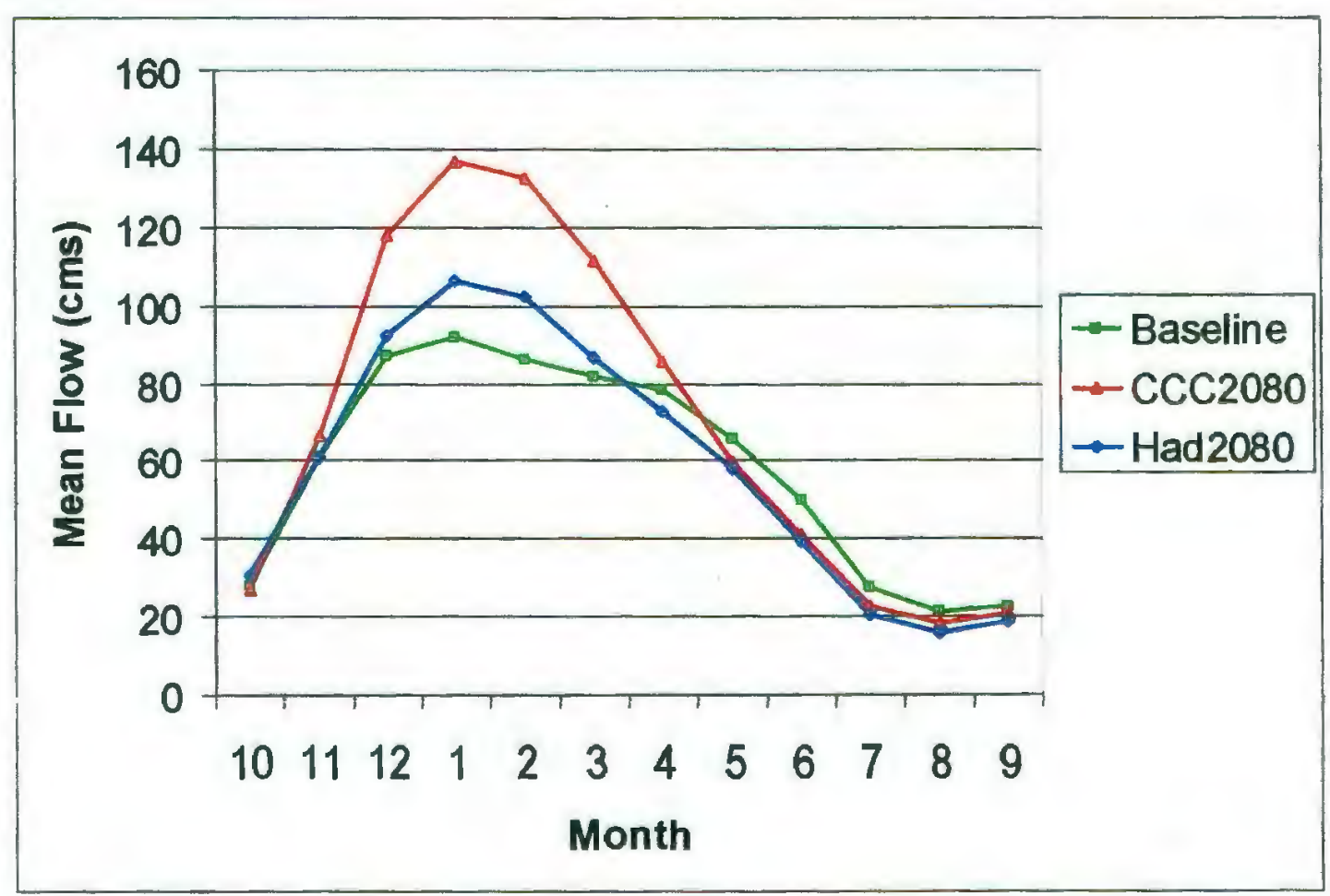

Figure 30: UCB mean monthly modeled flows of baseline (1971-2000) and 2080s 
Because the model is run for each month over a 30 -year cycle, it is also possible to examine seasonal maximum and minimum flows from each run, indicating periods when flooding or drought conditions may be a problem (See Table 12).

Between 1971 and 2000, the largest observed monthly flows (217.2 cubic meters-persecond (cms)) occurred during the winter (Jan-Mar) and the smallest monthly flows (14.4 cms) occurred during the summer (Jul-Sep). The largest maximum modeled monthly flows $(\sim 250 \mathrm{cms})$ occur during the fall (Oct-Dec) and winter periods of the CCC 2080s simulation. The smallest minimum modeled monthly flows $(3.1 \mathrm{cms})$ occur during the summer Hadley simulation. All simulations assume a historic release pattern of discharges from Timothy Lake, which in actuality can be managed somewhat to moderate downstream flood and drought conditions.

Table 12: Seasonal UCB measured and modeled mean, maximum, and minimum monthly flow rates

\begin{tabular}{|l|l|l|l|l|l|l|}
\hline $\begin{array}{l}\text { Climate } \\
\text { Scenario: }\end{array}$ & $\begin{array}{l}\text { Baseline } \\
\text { 30-year } \\
\text { 2000) } \\
\text { statistics: } \\
\text { Measured } \\
\text { Flow } \\
\text { (cms) }\end{array}$ & $\begin{array}{l}\text { Baseline } \\
\text { (1971-2000) } \\
\text { Modeled } \\
\text { Flow (cms) }\end{array}$ & $\begin{array}{l}\text { CCC } \\
\text { 2020s } \\
\text { Flow } \\
\text { (cms) }\end{array}$ & $\begin{array}{l}\text { Hadley } \\
\text { 2020s Flow } \\
\text { (cms) }\end{array}$ & $\begin{array}{l}\text { CCC } \\
\text { 2080s } \\
\text { Flow } \\
\text { (cms) }\end{array}$ & $\begin{array}{l}\text { Hadley } \\
\text { 2080s } \\
\text { Flow } \\
\text { (cms) }\end{array}$ \\
\hline $\begin{array}{l}\text { Jan to } \\
\text { Mar: }\end{array}$ & & & & & \\
\hline Mean Flow & 85.4 & 86.8 & 99.6 & 93.6 & 127.1 & 98.7 \\
\hline Max Flow & 217.2 & 162.0 & 183.0 & 175.6 & 248.1 & 191.4 \\
\hline Min Flow & 20.8 & 19.1 & 18.4 & 18.1 & 20.0 & 18.5 \\
\hline Apr to Jun: & & & & & & \\
\hline Mean Flow & 63.9 & 64.9 & 57.2 & 58.5 & 62.2 & 56.7 \\
\hline Max Flow & 133.1 & 117.7 & 113.7 & 109.3 & 130.4 & 112.1 \\
\hline Min Flow & 19.1 & 22.6 & 18.4 & 20.0 & 17.8 & 21.4 \\
\hline Jul to Sep: & & & & & & \\
\hline Mean Flow & 23.1 & 23.9 & 21.4 & 21.7 & 20.6 & 18.4 \\
\hline Max Flow & 44.3 & 50.4 & 41.2 & 41.7 & 41.7 & 35.9 \\
\hline Min Flow & 14.4 & 13.2 & 9.0 & 9.7 & 5.1 & 3.1 \\
\hline Oct to Dec: & & & & & & \\
\hline Mean Flow & 61.6 & 58.7 & 63.5 & 62.8 & 70.7 & 61.3 \\
\hline Max Flow & 175.4 & 190.3 & 238.1 & 208.0 & 252.5 & 190.5 \\
\hline Min Flow & 16.8 & 11.4 & 8.9 & 9.1 & 8.0 & 8.0 \\
\hline
\end{tabular}


While the overall change to flow from the UCB is important, it is also useful to anticipate where localized flows may change, for water resource management, aquatic species protection, and for the application of this research to other study areas. Figures 31 and 32 show the simulated change to baseline flow from each of the three major watersheds of the UCB during the highest and lowest flow seasons of the year. During high flow months (Dec-Feb) all simulations predict that average flow will increase most from the Upper Clackamas watershed and least from the Collowash watershed. During low flow months (Jul-Sep), all simulations predict that flow will decrease most from the Oak Grove Fork watershed and decrease least from the Collowash watershed.

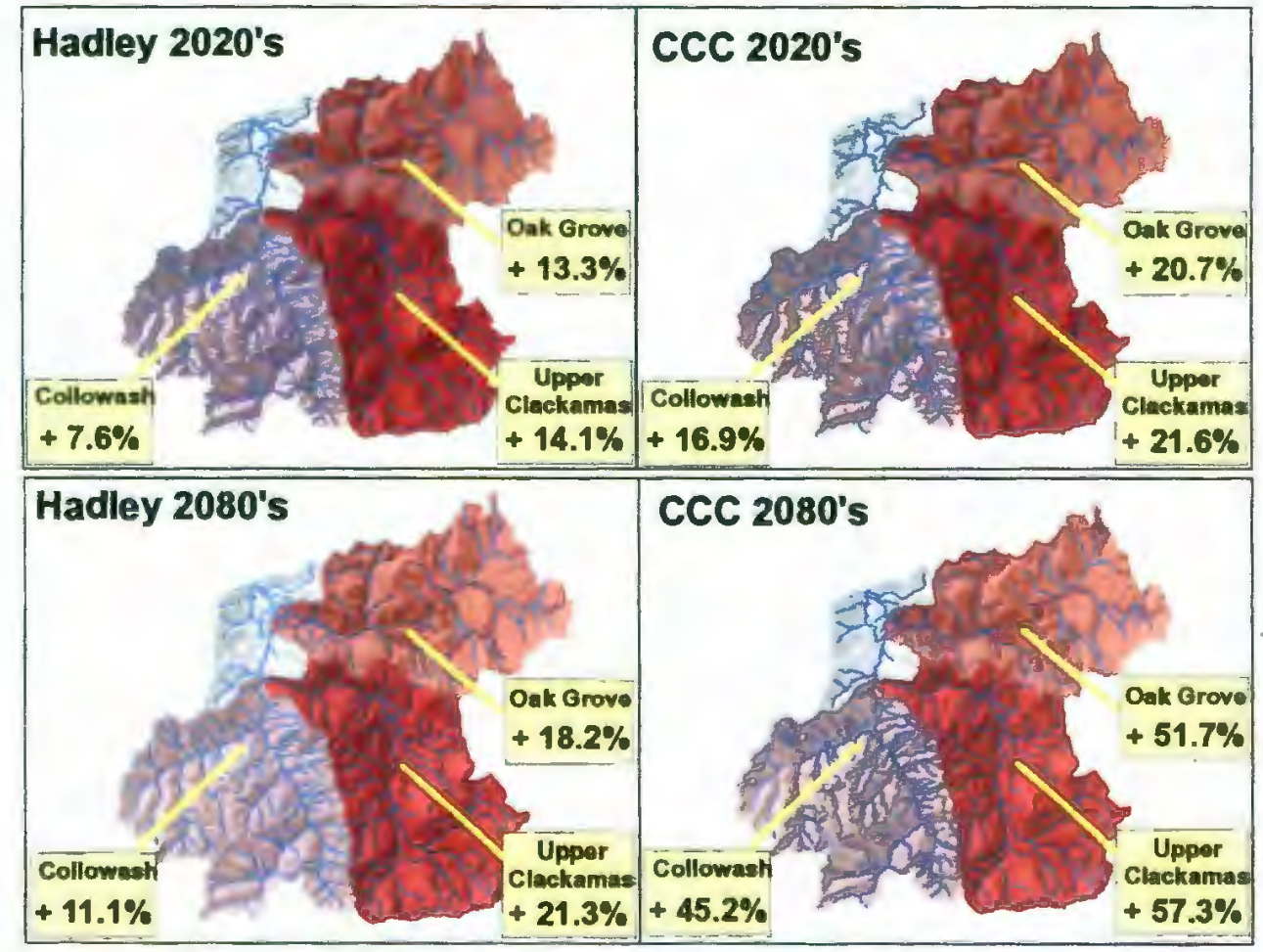

Figure 31: Modeled flow change from the baseline (1971-2000) period by UCB watershed during high flow months (December to February) 


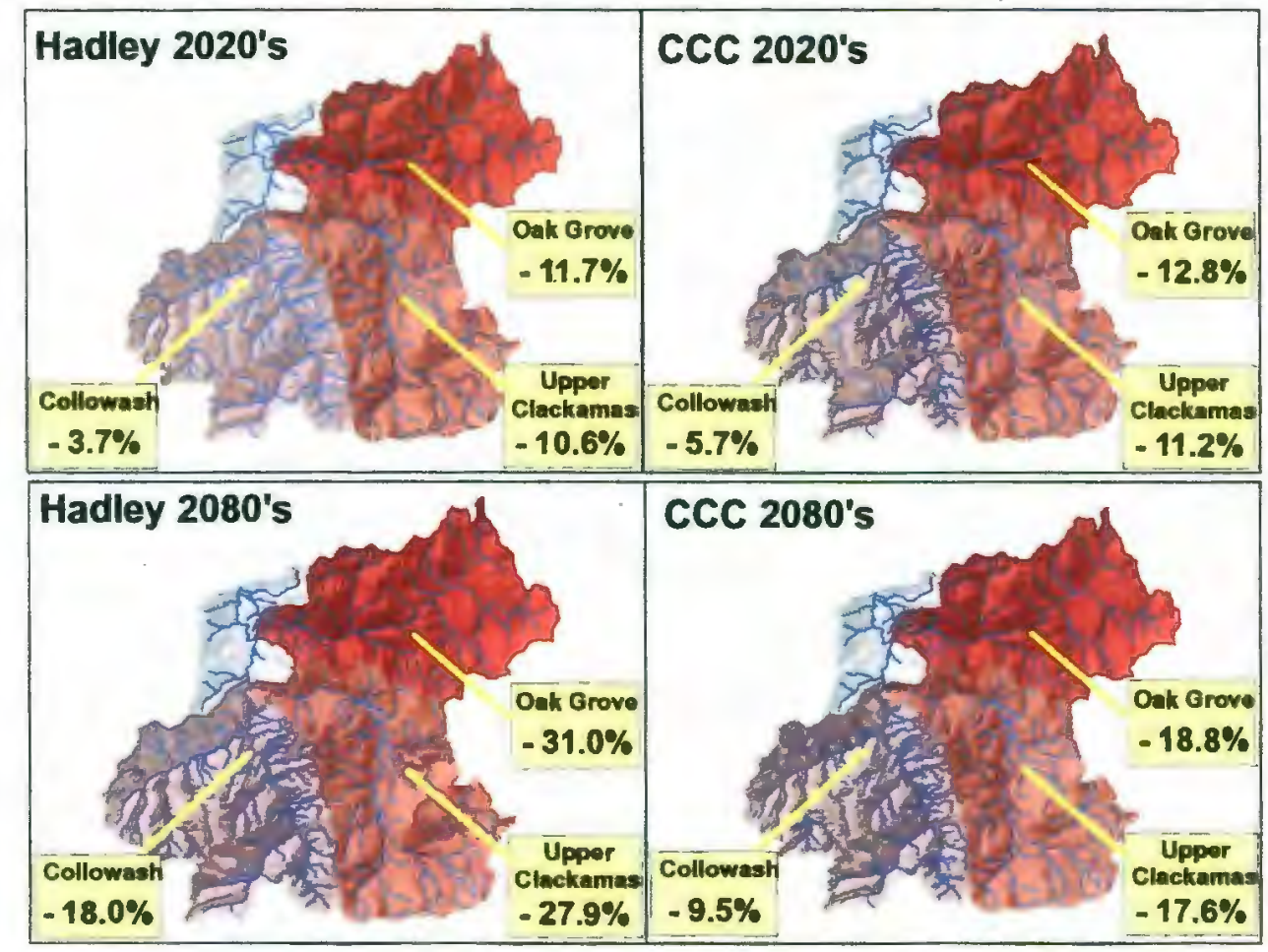

Figure 32: Modeled flow change from the baseline (1971-2000) period by watershed during low flow months (July to September)

As discussed earlier, the Collowash watershed is primarily underlain by the impermeable rocks of the Western Cascades, while the Oak Grove and Upper Clackamas watersheds have a larger proportion of permeable rocks from High Cascades formations. Tague and Grant (2004) postulated that areas of High Cascades geology would be better able to moderate the effects of climate change because of the storage of subsurface water. While the model includes the effect of underlying geology on flow, it contradicts this prediction, showing more dramatic effects on the High Cascade watersheds. These watersheds are higher and receive relatively larger amounts of snow fall than the Collowash watershed, though, and it may be that the 
loss of storage in the snowpack under future climate scenarios offsets the mitigating effect of more permeable groundwater storage.

A more detailed breakdown of changes to seasonal flows by each study cell (Figures 33-36) shows that the higher elevation areas to the east of the study area are forecasted to see the highest increases of runoff during the winter months and the highest decreases of runoff during the summer months, presumably because of the loss of snow in these areas, and because of increased winter precipitation (which would also more readily melt snow). Decreases in runoff during the spring are not distributed as consistently, possibly reflecting differences in precipitation changes between the climate scenarios. The simulations show smaller changes to fall runoff, and here it is also difficult to discern a consistent spatial pattern. 

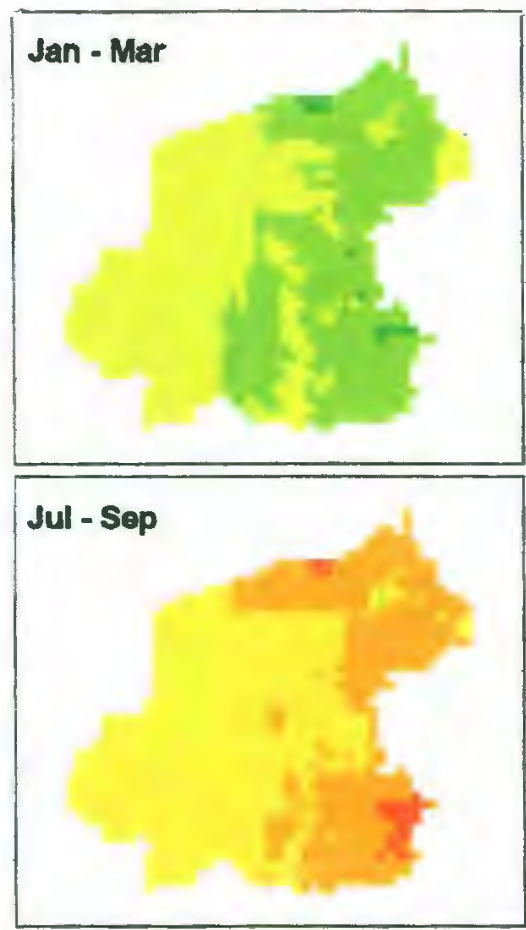

$-20 \%$ to $-10 \%$

$-10 \%$ to $-0 \%$

$+0 \%$ to $+10 \%$

$+10 \%$ to $+20 \%$

$+10 \%$ to $+20 \%$

Oct - Doc

$+20 \%$ to $+30 \%$

$>+30 \%$

Figure 33: Seasonal UCB flow change from baseline: 1971-2000, Hadley 2020s scenario
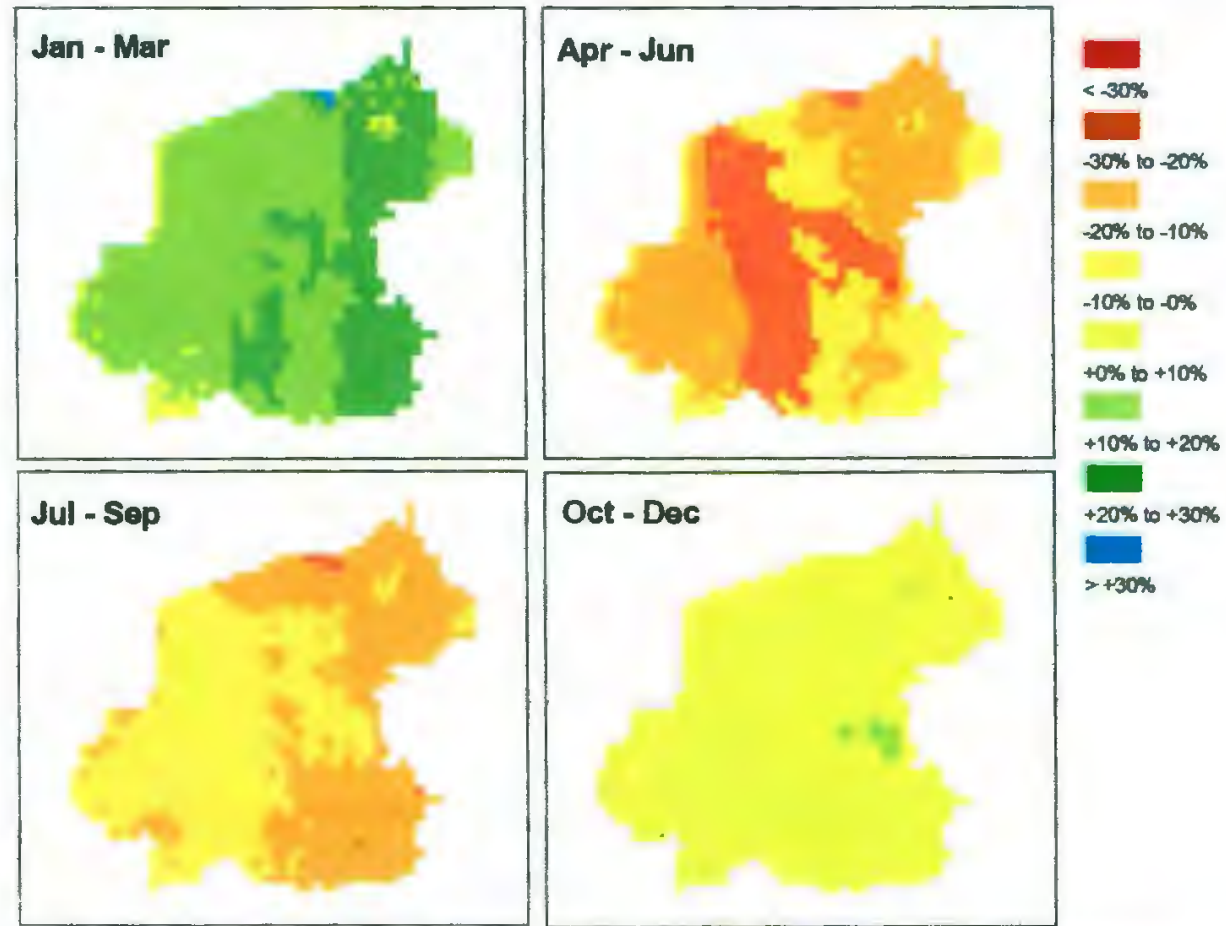

Figure 34: Seasonal UCB flow change from baseline: 1971-2000, CCC 2020s scenario 

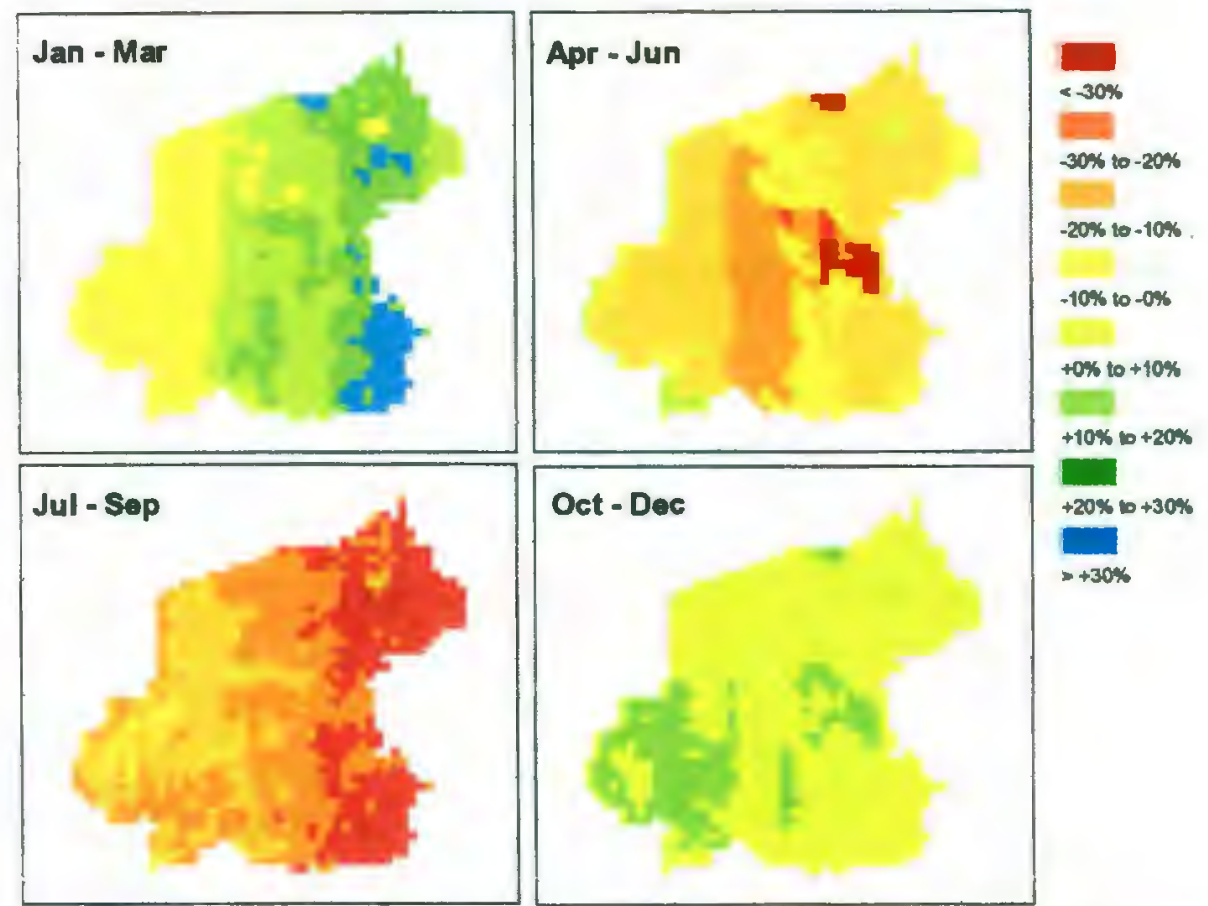

Figure 35: Seasonal UCB flow change from baseline: 1971-2000, Hadley 2080s scenario
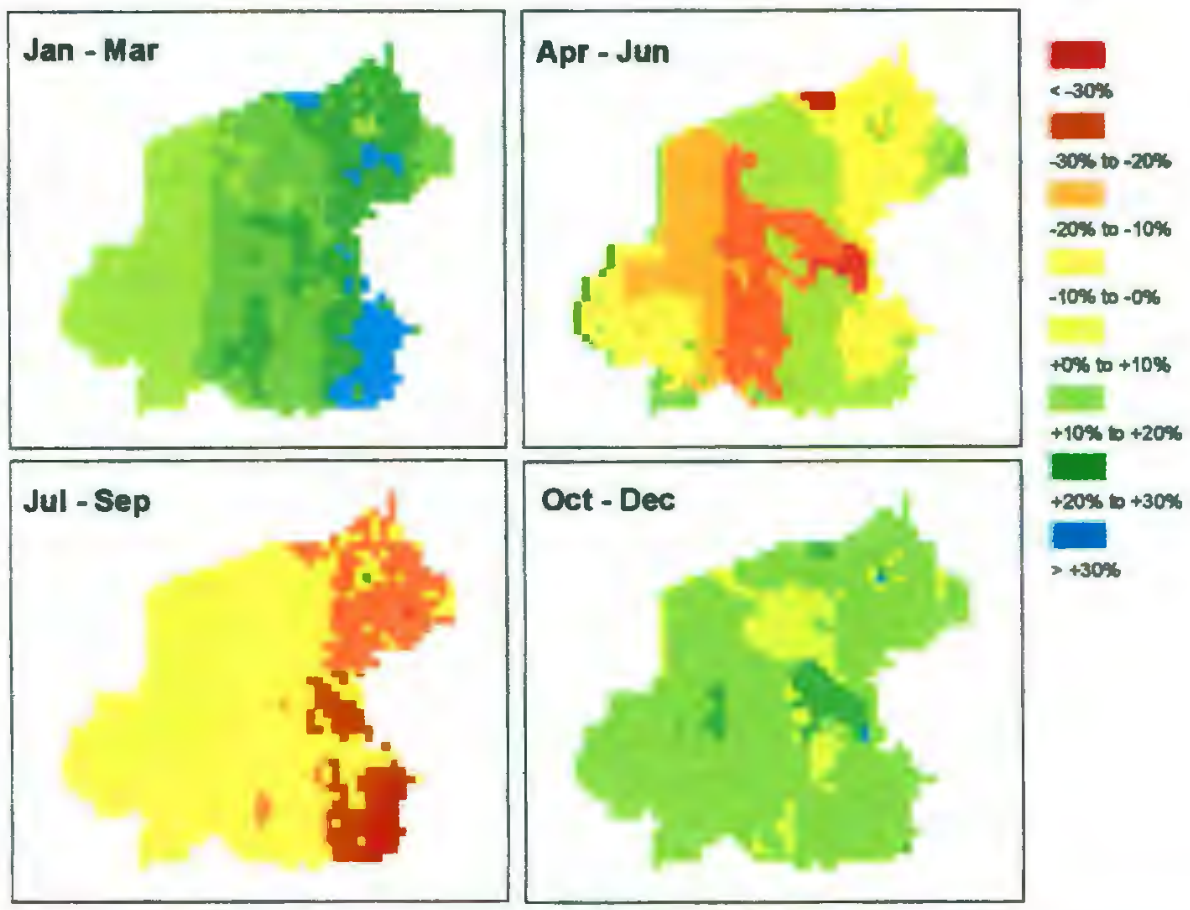

Figure 36: Seasonal UCB flow change from baseline: 1971-2000, CCC 2080s scenario 
A relationship between changes to runoff and elevation is shown consistently with both of the models in the wet season (Oct-Mar) assessments, but not in the dry season (Apr-Sep) assessments (Table 13 and Table 14). All model runs indicate a correlation between higher elevations and greater increases in wet season (Oct-Mar) runoff from the baseline period, presumably because of greater winter rainfall and reduced snowpack. In the dry season assessment, the CCC model shows a strong correlation between lower elevations and larger decreases to runoff in the 2020s and 2080s, but the Hadley model shows no clear relationship during the 2020 s, and a weaker opposite relationship during the 2080 s. These differences may be accounted for by the variation in monthly precipitation changes between the Hadley and CCC models, which may offset the effect of a lower snowpack.

Table 13: Seasonal modeled runoff change from baseline period by elevation range

\begin{tabular}{|l|l|l|l|l|}
\hline $\begin{array}{l}\text { Model } \\
\text { Climate } \\
\text { Scenario: }\end{array}$ & $\begin{array}{l}\text { CCC 2020s: } \\
\text { Runoff Change } \\
(\%)\end{array}$ & $\begin{array}{l}\text { Hadley 2020s: } \\
\text { Runoff Change } \\
(\%)\end{array}$ & $\begin{array}{l}\text { CCC 2080s: } \\
\text { Runoff Change } \\
(\%)\end{array}$ & $\begin{array}{l}\text { Hadley 2080s: } \\
\text { Runoff Change } \\
(\%)\end{array}$ \\
$\begin{array}{l}\text { Elevation } \\
\text { Range (m): }\end{array}$ & $\begin{array}{l}\text { Oct-Mar / Apr- } \\
\text { Sep }\end{array}$ & $\begin{array}{l}\text { Oct-Mar / Apr- } \\
\text { Sep }\end{array}$ & $\begin{array}{l}\text { Oct-Mar / Apr- } \\
\text { Sep }\end{array}$ & $\begin{array}{l}\text { Oct-Mar / Apr- } \\
\text { Sep }\end{array}$ \\
\hline $414-700$ & $+11.8 /-14.4$ & $+6.1 /-10.4$ & $+37.2 /-12.6$ & $+8.3 /-17.0$ \\
\hline $701-950$ & $+13.1 /-13.4$ & $+7.7 /-10.7$ & $+38.5 /-10.0$ & $+10.2 /-17.1$ \\
\hline $951-1200$ & $+13.7 /-12.4$ & $+8.7 /-10.6$ & $+37.9 /-6.8$ & $+10.9 /-16.9$ \\
\hline $1201-1450$ & $+13.9 /-12.2$ & $+9.6 /-11.0$ & $+40.0 /-6.9$ & $+12.4 /-17.6$ \\
\hline $1451-1871$ & $+14.1 /-9.6$ & $+10.7 /-9.9$ & $+45.5 /-7.0$ & $+16.9 /-19.1$ \\
\hline
\end{tabular}

Table 14: Correlation of seasonal modeled runoff change from baseline to elevation

\begin{tabular}{|l|l|l|l|l|}
\hline $\begin{array}{l}\text { Model } \\
\text { Climate } \\
\text { Scenario: }\end{array}$ & $\begin{array}{l}\text { CCC 2020s: } \\
\text { Correlation of } \\
\text { Runoff Change } \\
\text { (\%) } \\
\text { to elevation }\end{array}$ & $\begin{array}{l}\text { Hadley 2020s: } \\
\text { Correlation of } \\
\text { Runoff Change } \\
\text { (\%) } \\
\text { to elevation }\end{array}$ & $\begin{array}{l}\text { CCC } \\
\text { 2080s:Runoff } \\
\text { Correlation of } \\
\text { Runoff Change } \\
(\%) \text { to elevation }\end{array}$ & $\begin{array}{l}\text { Hadley 2080s: } \\
\text { Correlation of } \\
\text { Runoff Change } \\
(\%) \\
\text { to elevation }\end{array}$ \\
\hline $\begin{array}{l}\text { Wet Season } \\
\text { (Oct-Mar) }\end{array}$ & $+.173^{* *}$ & $+.316^{* *}$ & $+.173^{* *}$ & $+.275^{* *}$ \\
\hline $\begin{array}{l}\text { Dry Season } \\
\text { (Apr-Sep) }\end{array}$ & $+.207^{* *}$ & -.036 & $+.210^{* *}$ & $+.08^{* *}$ \\
\hline
\end{tabular}

$*=$ statistically significant with a $95 \%$ confidence, ${ }^{* *}=$ statistically significant with a $99 \%$ confidence 
While elevation is an important factor influencing runoff in the hydrologic model, land cover is also significant, particularly the effect of forested cover on transpiration and snowmelt. The model changes in runoff from baseline during the dry season and wet season were tested for a correlation with forested proportion of each cell using the Pearson's correlation test, and the results are presented in Table 15. . In all model simulations, there was a significant negative correlation between increased forest cover and dry season flows (i.e. with greater forest cover, dry season flows were reduced more). During the wet season, the CCC model (2020s and 2080s) showed a positive correlation between forest cover and increased flows, but the Hadley model showed no correlation during either time period. Although these relationships are statically significant, they are not strong correlations $(r<0.2)$, so it does not appear that forested cover is a very important factor in changes to runoff under future climate scenarios with this model.

Table 15: The correlation (Pearson coefficient) of seasonal modeled runoff change from baseline to forested cover.

\begin{tabular}{|l|l|l|l|l|}
\hline $\begin{array}{l}\text { Model } \\
\text { Climate } \\
\text { Scenario: }\end{array}$ & $\begin{array}{l}\text { CCC 2020s: } \\
\text { Correlation of } \\
\text { Runoff. Change (\%) } \\
\text { to forested cover }\end{array}$ & $\begin{array}{l}\text { Hadley 2020s: } \\
\text { Correlation of } \\
\text { Runoff Change (\%) } \\
\text { to forested cover }\end{array}$ & $\begin{array}{l}\text { CCC 2080s:Runoff } \\
\text { Correlation of } \\
\text { Runoff Change (\%) } \\
\text { to forested cover }\end{array}$ & $\begin{array}{l}\text { Hadley 2080s: } \\
\text { Correlation of } \\
\text { Runoff Change (\%) } \\
\text { to forested cover }\end{array}$ \\
\hline $\begin{array}{l}\text { Wet } \\
\text { Season } \\
\text { (Oct- } \\
\text { Mar) }\end{array}$ & $-.11^{* *}$ & $-.066^{*}$ & $-.195^{* *}$ & $-.147^{* *}$ \\
\hline $\begin{array}{l}\text { Dry } \\
\text { Season } \\
\text { (Apr-Sep) }\end{array}$ & +.00 & $+.12^{* *}$ & -.02 & + \\
\hline
\end{tabular}

$*$ = statistically significant with a $95 \%$ confidence, $* *$ = statistically significant with a $99 \%$ confidence 


\section{Monthly and Seasonal Changes to Snowpack}

As discussed previously, the climate simulations anticipate a significant reduction in annual snowfall. In addition, snowmelt is also modeled to accelerate with higher temperatures, and all simulations shows a consequent decrease in monthly snow accumulation, as measured as the average SWE of the UCB (see Figure 37). While mean SWE for the area still peaks around the end of February in the 2020s, it drops by nearly half from the baseline period $(17.0 \mathrm{~cm}$ to $10.8 \mathrm{~cm}(\mathrm{CCC}) / 8.6 \mathrm{~cm}$ (Hadley). The decrease by the 2080 s is even more dramatic, when mean snowpack is forecasted to peak around the end of December by the CCC simulation at only $2.9 \mathrm{~cm}$, and peak around the end of January by the Hadley simulation at only $2.1 \mathrm{~cm}$.

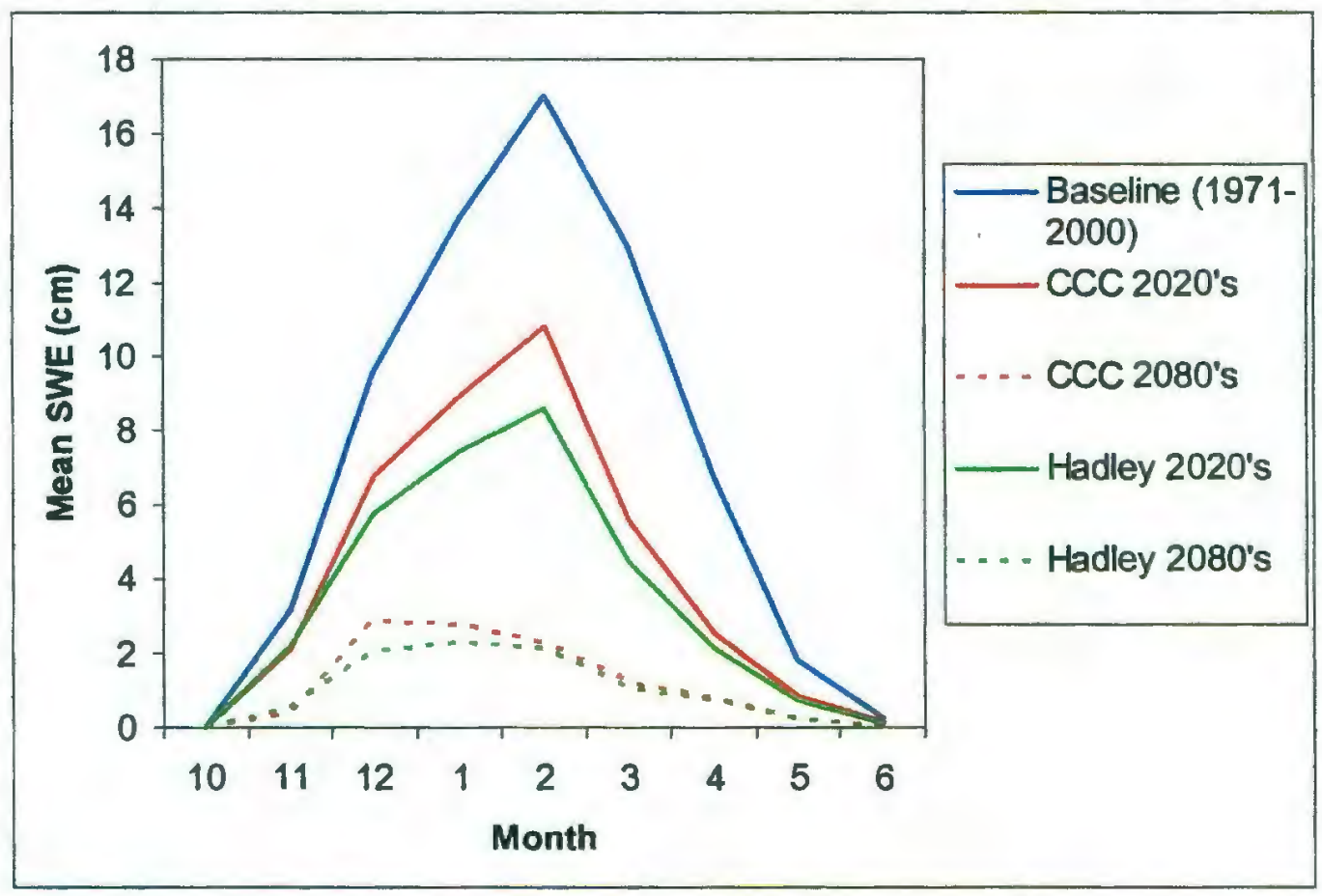

Figure 37: Average modeled snow water equivalent of the UCB under five scenarios 
The spatial distribution of changes to snowpack is shown in Figures 38 and 39. Modeled snowpack is generally greater in the high-elevation areas to the east, particularly in the plateau area to the southeast (see Figure 2), which in the contemporary period (1971-2000), is simulated to retain a healthy snowpack $(>12 \mathrm{~cm}$ SWE per cell) at the beginning of May during average years. The contemporary assessment also shows almost all of the UCB to be covered $(>2 \mathrm{~cm}$ mean SWE per cell) with snow on March 1st. In the CCC assessment, the 2020s distribution of snowpack on March 1st is much diminished and in the 2080s assessment, March 1st snowpack is clearly lower for most areas than the contemporary May 1st snowpack, signifying a dramatic transformation of the hydrologic regime. The Hadley assessment of snow distribution shows very similar results for both periods. Snow water equivalent decreases substantially in both the 2020 s and 2080 s assessments, with the western half of the UCB losing virtually all of its snow accumulation, and the eastern portions holding very little spring (May 1) snowpack by the 2080 s. 


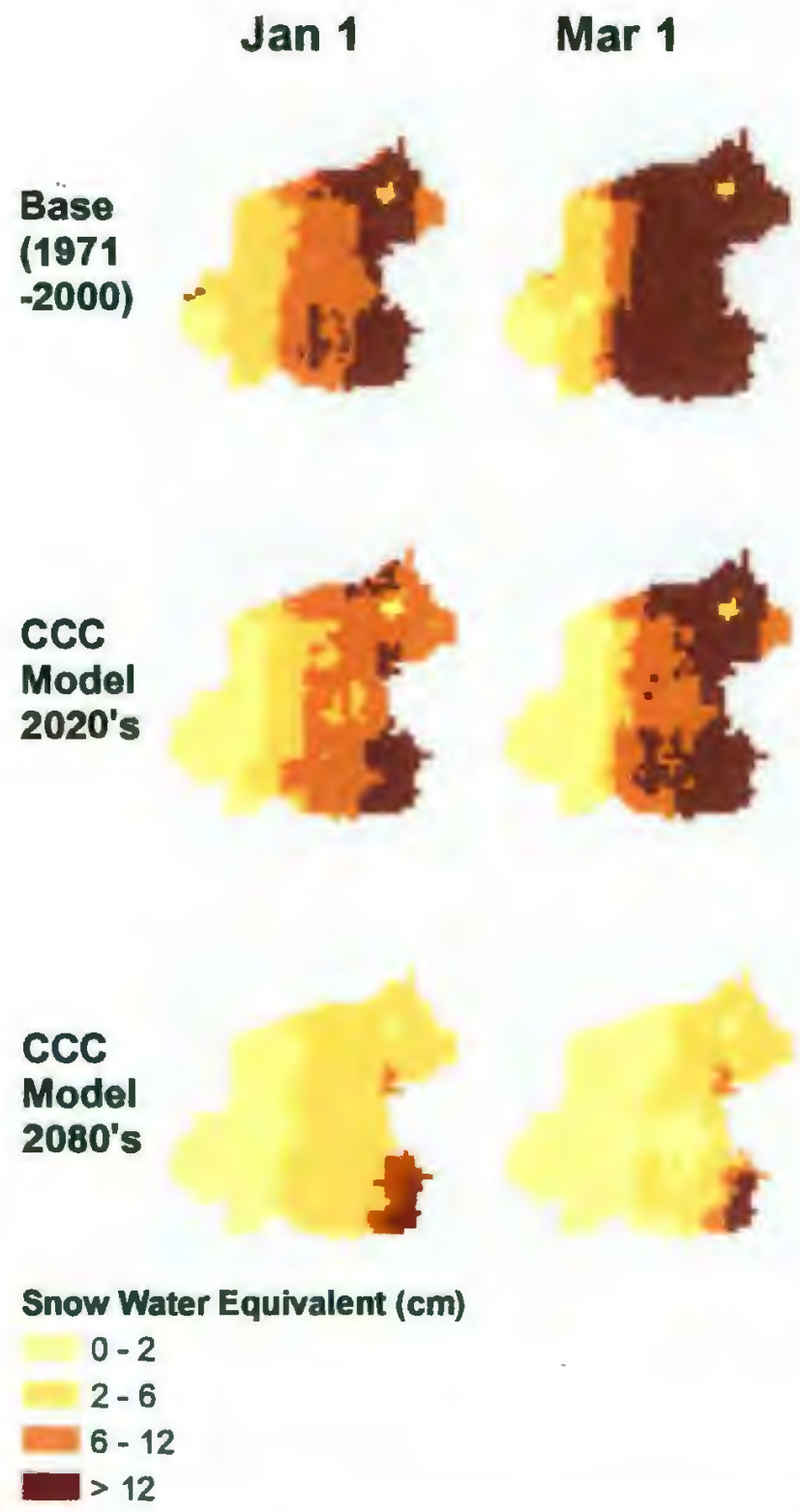

Figure 38: Modeled distribution of snowpack in the UCB with the CCC simulation 


\section{Jan 1}

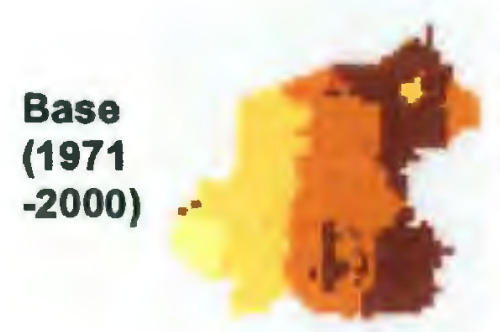

Mar 1

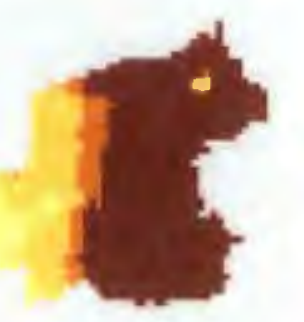

Hadley

Model

2020 's
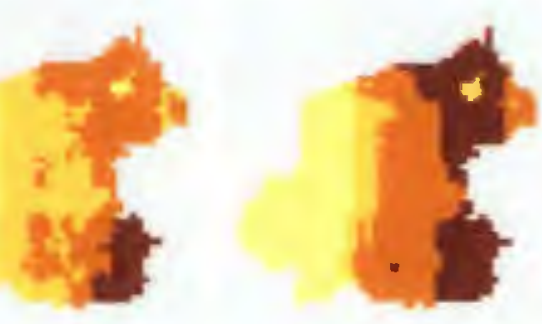

\section{May 1}

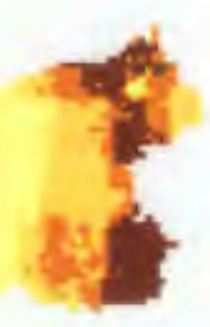

\section{Hadley}

Model

2080's

\section{Snow Water Equivalent (cm)}

$0-2$

$2-6$

$6-12$

$>12$

Figure 39: Modeled distribution of snowpack in the UCB with the Hadley simulation

\section{Discussion}

The simulations of climate change in the UCB demonstrate some clear hydrologic trends that are likely to occur if the estimates of climate change from the Hadley and CCC GCMs and the methods of this assessment are correct. 
Evapotranspiration will increase throughout the basin (see Table 11) and snowpack will diminish greatly (see Figures 38 and 39), in a fairly uniform pattern. These effects will diminish spring and summer flows moderately by the 2020 s period and significantly by the 2080 s period. Increasing rainfall during both periods will lead to higher flows during the winter months. During the 2020s, the models are in fairly close agreement about the magnitude of these changes, although the $\mathrm{CCC}$ model demonstrates somewhat more pronounced effects (greater increases to winter flows and greater decreases to summer flows) than the Hadley model. The magnitude of this change and the month-to-month variation during the 2080s time period is less certain. Variations occur between the two simulations of the 2080 s principally because of disagreement over increases to precipitation. In the CCC simulation, large increases to precipitation offset some of the losses to spring and summer runoff but portend very high flows during the fall and winter months. In the Hadley 2080s simulation, precipitation increases are modest and winter increases to runoff are largely unchanged from the 2020s assessment, but reductions to spring and summer flow are the most severe of any of the simulations. Annual runoff remains largely unchanged from the baseline period in all simulations except the CCC 2080 run, which projects it to increase substantially $(+20.8 \%)$ because of greater annual precipitation inputs.

Spatially these changes are more pronounced in the high elevation areas of the UCB (primarily to the east) that receive more runoff from snow, although the relatively permeable geology and consequent ground water storage of these areas moderate these effects somewhat. Of the three major watersheds, the Upper Clackamas appears most vulnerable to changes, both in the form of wet season 
flooding and dry season droughts because it currently receives a large amount of its runoff from snowpack and unlike the Oak Grove fork watershed, it has no managed reservoirs that could be used to mitigate some of theeffects of a warmer climate. Forested land cover may also amplify dry season reductions to runoff, but this correlation is not as strong as is the correlation to elevation.

The findings of this study agree with the major findings of several other simulations of the hydrologic effects of climate change in snow-melt dominated basins. Of the studies reviewed for this thesis, which use different types of models and climate change scenarios, all showed that warmer temperatures can be expected to reduce snowpack in the future, leading to earlier seasonal runoff. These studies occurred in locations as varied as the Swiss Alps (Seidel et al. 1998), southern Germany and the central Alps (Kunstmann et al. 2004), the western Himalayas of India (Singh and Bengtsson 2004), a Mediterranean Basin (Chang et al. 2002), the Catskill Basin of New York (Frei et al. 2002), and various mountainous basins throughout the western United States (Van Katwijk et al. 1993; Stonefelt et al. 2000). While these studies largely agree about a trend towards a reduced snowpack during the $21^{\text {st }}$ century, they differed in their assessment of the severity of disruptions to the timing and quantity of runoff, and whether annual runoff would increase or decrease.

These effects are largely dependent on physical variations between geographical areas and the local prediction of changes to precipitation during the $21^{\text {st }}$ century. In the UCB study, the 2080s results are strongly driven by a forecast of greatly increased annual precipitation $(+27.1 \%)$ by the $\mathrm{CCC}$ model but a more moderate increase $(+12.4 \%)$ by the Hadley model; in a similar study of hydrologic 
impacts of climate change in the Conestaga Basin of Pennsylvania (Chang 2003), the opposite condition affected the study, with larger increases in 2030 precipitation being forecast by the Hadley model $(+7.7 \%)$, but an actual decrease being forecasted by the CCC model (-5.9\%). In the Frei et al. 2002 study in the Catskills, which also uses a Thornthwaite soil water balance approach, the authors found that the basin response to warmer temperatures will be largely dependent on precipitation changes. They forecasted a range for annual runoff yields from $-30 \%$ by the 2080 s depending on these changes. Stonefelt et al. (2000) find agreement in their study, determining that precipitation is most important for annual water yield, and temperature most important for the timing of streamflow.

Recent studies in other environments also show similar results but differ in some key findings. Dankers and Christensen (2005) modeled the potential of climate change based on an A2 SRES scenario, which assumes steady population growth and continued reliance on fossil fuels during the $21^{\text {st }}$ century, in the Tana River Basin, a $16,000 \mathrm{~km}^{2}$ subarctic catchment located in Northern Finland and Norway. They used a new model (TANAFLOW) at a ten-day temporal scale and a $1 \mathrm{~km}^{2}$ spatial scale to model water balance and snow accumulation and melt. Higher precipitation $(+25 \%)$ and a moderate increase in evapotranspiration $(+15 \%)$ simulated by climate models led to a large overall increase in runoff $(+39 \%)$ for the 2080 s period $(2071-2099)$. As in this study, increased temperature $\left(+5.2 \mathrm{C}^{\circ}\right)$ led to a delay in snow accumulation (2-3 weeks) and earlier snowmelt ( 3 weeks), but unlike in this study, projections of maximum winter SWE actual increased, because of the large increases in winter precipitation and the relatively colder temperature of the study area. In the Satluj 
River Basin $\left(22,275 \mathrm{~km}^{2}\right)$ of the Western Himalayas of India, Singh and Bengtsson (2004), used a snowmelt model (SNOWMOD) to assess the effects of warmer temperatures $(+1,2,3 \mathrm{C})$ on daily runoff. While warmer temperatures predictably resulted in less snow accumulation and consequent snowmelt in the lower parts of the basin, these effects were offset by increasing melt from glaciers and snow fields of the upper basin. Projected annual water supply was not affected, although summer flows were reduced.

The results of this study generally agree with other simulations in the Pacific Northwest, with a few differences. The UCB results match those of broad studies of the Columbia Basin (Hamlet and Lettenmaier (2000) and Payne et al. (2004), anticipating reduced snowpack and earlier runoff. The Hamlet and Lettenmaier (2000) study is especially useful for comparison to this study because it addresses similar periods (2020s and 2090s) using one of the same input climate models (HadCM2) as an input. As with this study, it showed an increasingly earlier spring melt during the $21^{\text {st }}$ century, but the reductions of peak (March $1^{\text {st }}$ ) SWE in the UCB in the 2020 s are larger $(-49 \%)$ than those modeled by Hamlet and Lettenmaier for the entire Columbia Basin (-15\%). This discrepancy can be attributed to the large proportion of the UCB that is at moderate elevations $(1.52 \%$ of the UCB is located below 500 meters elevation, $98.46 \%$ of the UCB is located between 500 and 1700 meters, and only $0.2 \%$ of the UCB is located above 1700 meters), compared to the Columbia Basin, which encompasses large areas at high elevations and with continental climates that may be less sensitive to small increases in temperature (U.S.Geological Survey - EROS Data Center 1999). The HadCM2 simulation in the 
Hamlet and Lettenmaier study also forecasted that winter runoffs will increase while summer runoffs decrease, but effects on annual runoff differ from those of this study (2020s, change to annual runoff: Hamlet and Lettenmaier: $+23 \%$ vs. UCB: $+1 \%$, 2090 s, change to annual runoff: Hamlet and Lettenmaier: $+12 \%$ vs. UCB (2080s): $+0 \%$ ). The U.S. National Climate Assessment (USGCRP 2000) agrees that annual water availability in the Pacific Northwest will decrease late in the $21^{\text {st }}$ century more severely with the Hadley GCM than the CCC GCM. This assessment also determined that more precipitation will likely fall during the winter, exasperating potential flood hazards, and that a smaller snowpack will lead to summer shortages.

A study by Shelton (1999) in an eastside Oregon basin of comparable size to the UCB (The Upper Crooked River, $3562 \mathrm{~km}^{2}$ ) offers an interesting comparison to the results of this study. Shelton also used a soil water balance approach to simulate the effects of $21^{\text {st }}$ century climate change on water availability, assuming a doubling of carbon dioxide. His study results agree with the UCB findings that an increase in winter precipitation will not result in a larger snowpack if temperatures warm significantly. Shelton also found that a reduced snowpack and greater evaporation throughout the year can be expected to accentuate the contrast between the Pacific wet and dry seasons, as is the case in the UCB simulation. According to these findings, however, annual runoff in the Crooked River basin will likely be diminished, which is not the case in the UCB study. Although these basins are located physically close to each other and have similar elevation and size profiles, their positions on opposite sides of the Cascade Range means that they do have distinctly different (wet vs. arid) 
climates, as well as different underlying geology regimes (the Crooked River is situated on an elevated lava plain).

The UCB study also illustrates the importance of using local assessments to complement broad-scale studies, which may differ in their findings. Amell (2003) used a macro-scale ( 0.5 degree grid) water balance model to assess the effects of global climate change and potential water stress globally. He found that between the baseline period (1961-1990) and the 2050s in the general area of this study (west slope Cascades and valleys of northern Oregon), annual runoff can be expected to decrease $-10 \%$ to $-20 \%$ with a Hadley (HadCM3) assessment and not show any significant change with the Canadian model (CGCM2). These results differ with the findings in this study of virtually no increase in annual runoff with inputs from an earlier version of the Hadley model (HadCM2) and a significant increase (2080s) using the Canadian Climate model. The seasonal results of this study do agree with Arnell's assessment that increases in runoff globally may be expected to occur disproportionately during wet seasons, and Arnell suggests that this may actually cause more stress on societies if water is not stored for dry seasons. The UCB results also agree with the general assessment of Viviroli and Weingartner (2004) that catchments that are dominated by snow are more sensitive to climate changes, and suggest that those most sensitive are located in areas of moderate elevation and climate, where small degrees of warming may change snow to rain.

While a comparison with these other studies reinforces the UCB findings, it is important to emphasize that the simulation is an estimate based on the results of global climate models that are complex and differ in their own assessments. The effects of 
climate change are uncertain because of complex interactions between earth and atmospheric systems. For example, a greater supply of $\mathrm{CO}_{2}$ in the atmosphere can generally be expected to increase plant growth while decreasing transpiration, which might preserve more water for runoff (Wigley and Jones 1985). It is uncertain what this reduction would be and whether it would be offset by a coincident increase in canopy leaf area or limited by available nutrients (Gifford 1988, Van Katwijk et al.1993, Shelton 1999). Climate change may also be expected to change the composition of vegetation in the UCB in the long term and affect the frequency of forest fires (Mote et al. 2003). The modeled approach used here does not attempt to incorporate these uncertain processes. In addition to the previous assumptions about hydrologic conditions that the model makes, it also introduces other assumptions about climate change when it uses GCM data: (1) The anthropogenic release of carbon dioxide and other greenhouse gases will occur at the rate assessed by the GCMs used in this study (a doubling by 2100); (2) the GCMs validation with historic data is sufficient to support their application during the $21^{\text {st }}$ century. Estimations for certain time periods (2020s and 2080s) are also based on a contemporary 30-year climate cycle, and actual conditions during these periods will be influenced by climate variability, especially PDO and ENSO cycles, which are important drivers of river runoff in the Pacific Northwest and are expected to be so in the future (USGCRP 2000; Mote et al. 2003, Beebee and Manga 2004; Stewart et al. 2005). Climate during these periods may also be affected by other factors that can occur unexpectedly, such as fluctuations in incoming solar radiation and volcanic eruptions. 


\section{CONCLUSIONS}

An assessment of the Upper Clackamas Basin with a fairly simple distributed, GIS-based hydrologic model is found here to be effective at simulating contemporary streamflow and in projecting future changes based on the estimates of global models of $21^{\text {st }}$ century climate change. The projected changes to snowpack are the most dramatic, and suggest that similar basins that are dependent on snowmelt but at moderate elevations and climates may be most affected by warming temperatures.

The Struma River model was modified somewhat with high quality data available to better simulate the conditions of this small Cascades basin, including the addition of components to simulate base flow, differences in underlying geology, additional snow melting from rain-on-snow, and increased rates of direct runoff during December and January. This adjusted model was used in the final assessment, and performed equally well at producing monthly flows during a contemporary calibration period, $1971-1985(\mathrm{NS}=.836)$ and a validation period $1986-2000(\mathrm{NS}=.838)$ with input data from a PRISM climate model and readily available GIS data of the physical characteristics of the study area. The model did not appear to capture the quantity of snow accumulation well, but an evaluation of this component is limited because there are only two sites in the study area with snow data. The distributed nature of the assessment allowed for the analysis of runoff patterns, evapotranspiration, and snow accumulation across the basin, showing the importance of large snowpack in the high elevation areas in the east of the basin for sustaining summer flows. The strength of this assessment is limited by several simplifying assumptions about hydrologic processes in the study area, the coarse temporal (monthly) and spatial $\left(1 \mathrm{~km}^{2}\right)$ scales 
used, and the availability of flow data for validation from only one station. Nevertheless, it shows that this distributed hydrologic model is effective at predicting monthly runoff from a medium-sized Pacific Northwest watershed where snowmelt is the most important contributor to runoff.

The results of this study clearly support its hypothesis that climate change projected by global models of increased greenhouse gas concentrations would significantly alter runoff patterns from the Upper Clackamas River Basin. The study finds that diminished snowpack and increased winter temperature would likely cause earlier runoff, larger winter flows, and diminished summer flows. These effects are moderate and fairly consistent during the two 2020 s assessments $(+7.8 \%$ to $+14.7 \%$ increases in winter flows, $-9.2 \%$ to $-10.4 \%$ decreases in summer flows) but more pronounced and divergent in the two 2080 s assessments $(+13.7 \%$ to $+46.4 \%$ increases in winter flows, $-13.8 \%$ to $-23.0 \%$ decreases in summer flows). Overall, a larger proportion of annual runoff occurs during the wet season, although in all four assessments (2020s and 2080s) peak runoff still occurs in the same month (January). Unexpected findings of this study are the very large magnitude of the loss in snowpack ( $36.5 \%$ to $49.4 \%$ reduction in peak snowpack in the 2020 s assessment and $82.9 \%$ to $87.6 \%$ reduction in peak snowpack in the 2080 s assessment), and disagreement over implications for annual runoff from two common GCMs (while both 2020 s assessments show a slight increase in annual runoff from the baseline period, the 2080s Hadley assessment shows no change in annual runoff from the baseline period but the $2080 \mathrm{~s} \mathrm{CCC}$ assessment shows a $20.8 \%$ increase). The results of this study generally agree with those of other studies in the Columbia Basin, but 
show more pronounced effects on snow accumulations, presumably because of the smaller size of the UCB and its moderate elevation and Westside Cascades climate, which make its snowpack susceptible to the effects of small increases in temperature.

Future opportunities for related research include the use of different GCM scenarios and other hydrologic models, which may simulate physical processes at varying temporal and spatial scales, to assess the impacts of climate change on the water resources of the UCB. The use of different inputs and models would provide water resources managers with a measure of confidence in the results of these assessments and a range of uncertainty to work within. Water resources managers would also benefit from applied studies to evaluate the ramifications on water resource uses of the Clackamas River from anticipated changes to the quantities of seasonal and flows. The most important applications of these studies would probably be for the instream uses of hydropower production, and for aquatic habitat in the area, particularly for salmon, which have been listed under the Endangered Species Act of 1973. Hydropower managers carefully plan seasonal, monthly, and daily releases of water based on assumptions about seasonal runoff, in order to produce the most costefficient electricity while controlling flooding in the lower basin and protecting aquatic resources and recreational uses of the river. Disruptions to these flows from climate change will likely require a reevaluation of these practices, and possibly changes to infrastructure. Likewise, salmon depend on cool, steady flows during spawning periods and may be impacted if reduced flows lead to warmer temperatures and less dissolved oxygen in spawning reaches. Increased winter flooding may also 
scour stream habitat and affect aquatic communities that are adapted to current conditions,

Several assessments of the impacts of $21^{\text {st }}$ century climate change have anticipated that in the Pacific Northwest, changes to the timing and availability of our water resources are of great concern to our economy and natural resources. These assessments predict that increased rain and reduced snow during the winter months will lead to disruptions to the hydrologic cycle, including greater risks of winter flooding and lower summer flows. This study in the Upper Clackamas Basin agrees with these studies and suggests that these effects may be most pronounced in similar smaller mid-elevation basins where snow accumulations are currently significant but winter temperatures are moderate. In these basins, distributed hydrologic models can assist planners to anticipate the possible effects of climate change and their implications on local water resource uses. 


\section{REFERENCES CITED}

Anderson, J.L. 1978. The Stratigraphy and structure of the Columbia River basalt in the Clackamas River drainage (M.S. Thesis): Portland State University

Arnell, N.W. 2003. Effects of IPCC SRES emissions scenarios on river runoff: A global perspective. Hydrology and Earth System Sciences 7 (5): 619-641

ASCE Task Committee. 1993. Criteria for evaluation of watershed models. Journal of Irrigation and Drainage Engineering 119 (3): $429-443$

Beebee, R.A., and M. Manga. 2004. Variation in the relationship between snowmelt runoff in Oregon and ENSO and PDO. Journal of the American Water Resources Association 40(4):1011-1024

Bolton, D. 1980. The computation of equivalent potential temperature. Monthly Weather Review 108: 1046-1053

Carpenter, K. D. 2003. Water-Quality and algal conditions in the Clackamas River Basin, Oregon, and their relations to land and water management. U.S. Geological Survey, Water-Resources Investigations Report. 02-4189

Cayan, D.R., S.A. Kammerdiener, M.D. Dettinger, J.M. Caprio, and D.H. Peterson. 2001. Changes in the onset of Spring in the Western United States. Bulletin of the American Meteorological Society 82 (3): 399-415.

Chang, H. 2003. Basin hydrologic response to changes in climate and land use: The Conestoga River Basin, Pennsylvania. Physical Geography 24 (3): 222-247

Chang, H., C. G. Knight, M. Staneva, and D. Kostov. 2002. Water resources impacts of climate change in southwestern Bulgaria. GeoJournal 57: 115-124

City of Oregon City. 2000. Historic context statement. http:/www.orcity.org/community-develop/planning/historical_context.htm. Accessed April 2005.

Collier, M. and Webb, R. 2002. Floods, droughts, and climate change. The University of Arizona Press, Tucson

Dankers, R., and O.B. Christensen. 2005. Climate change impact on snow coverage, evaporation, and river discharge in the sub-arctic Tana Basin, Northern Feenoscandia. Climatic Change 69: 367-392 
Daly, C., R.P. Neilson, and D.L. Phillips. 1994. A statistical-topographic model for mapping climatological precipitation over mountainous terrain. Journal of Applied Meteorology 33: 140-158

Daly, C., P. Pasteris, W.P. Gibson, G.H. Taylor, and G. L. Johnson. 2002. A knowledge-based approach to the statistical mapping of climate. Climate Research 22 (2): 99-113

Dart, J.O., and D.M. Johnson. 1981. Oregon: Wet, high, and dry. The Hapi Press, Portland, OR.

Dunne, T., and L.B. Leopold. 1978. Water in environmental planning, W. H. Freeman, New York

Ferguson, B. 1996. Estimation of direct runoff in the Thornthwaite water balance. Professional Geographer. 48 (3): 263-271

Flaton, G.M., G.J. Boer, W.G. Lee, N.A. McFarlane, D. Ramsden, M.C. Reader, and A.J. Weaver. 2000. The Canadian Centre for Climate Modelling and Analysis global coupled model and its climate. Climate Dynamics 16: 451-467

Frei, A., R.L. Armstrong, M.P. Clark, and M.C. Serreze. 2002. Catskill Mountains water resources: Vulnerability, hydroclimatology, and climate-change sensitivity. Annals of the Association of American Geographers 92 (2): 203-224

Gerig, A.J. 1985. Soil survey of Clackamas County area, Oregon. U.S. Department of Agriculture, Soil Conservation Service.

Gerrard, J. 2000. Fundamentals of soils: Routledge, Oxford

Gifford, R.M. 1988. Direct effects of CO2 concentrations on vegetation. Greenhouse: Planning for Climate Change. CSIRO, Melbourne, Australia

Glassman, J.R. and G.F. Kling. 1980. Origin of soil material on foothill silts of Willamette Valley, Oregon. Soil Science Society of America 44 (1): 123-130

Glenn, J. 1965. Late Quaternary sedimentation and geologic history of the north Willamette Valley, Oregon (Ph.D. thesis): Oregon State University

Hamlet, A. and D. Lettenmaier. 2000. Effects of climate change on hydrology and water resources in the Columbia River Basin. Journal of the American Water Resources Association 35 (6): 1597-1622 
Harr, R., R. Fredriksen, and J. Rothacher 1979. Changes in streamflow following timber harvest in southwestern Oregon. U.S. Department of Agriculture Research Paper PNW-249

Ingebritsen, S.E., D. R. Sherrod, R.H. Mariner. 1992. Rates and patterns of groundwater flow in the Cascade Range volcanic arc, and the effect on subsurface temperatures. Journal of Geophysical Research 97 (B4): 4599-4627

Intergovernmental Panel on Climate Change (IPPC). 2001. Third assessment report Climate change. http://www.ipcc.ch/. Accessed May 2005.

Intergovernmental Panel on Climate Change (IPPC) Data Distribution Centre. 2005. http://ipcc-ddc.cru.uea.ac.uk/. Accessed May 2005.

Johns, T.C., R.E. Carnell, J.F. Crossley, J.M. Gregory, J.B. Mitchell, C.A. Senior, S.B. Tett, and R.A. Wood. 1997. The second Hadley Centre coupled ocean-atmosphere GCM: Model description, spinup, and validation. Climate Dynamics 13: 103-134

Johnson, M.G. and R.L.Beschta. 1981. Seasonal variation of infiltration capacities of soils in western Oregon, U.S. Department of Agriculture, Forest Service, Pacific Northwest Forest and Range Experiment Station

Jones, J. A. 2000. Hydrologic processes and peak discharge response to forest removal, regrowth, and roads in 10 small experimental basins, Western Cascades, Oregon. Water Resources Research, 36 (9): 2621-2642

Jones, J.A. 1997. Global hydrology: Processes, resources, and environmental management. Addison-Wesley Pub Co., London

Key, C., D. Fagre., and R. Menicke. 1998. Glacier retreat in Glacier National Park, Montana. U.S. Geological Survey Professional Paper 13686-J

Klocke, N. and G. Hergert. 1996. How soil holds water. University of Nebraska Lincoln, Institute of Agriculture and Natural Resources http://ianrpubs.unl.edu/fieldcrops/g964.htm. Accessed November 2004.

Knight, C. G., H. Chang, M. Staneva, and D. Kostov. 2001. A simplified model for simulating runoff: The Struma River GIS. Professional Geographer 53 (4): $532-$ 543

Kunstmann, H., K. Schneider, R. Forkel, and R. Knoche. 2004. Impact analysis of climate change for an alpine catchment using high resolution dynamic downscaling of ECHAM4 time slices. Hydrology and Earth System Sciences 8 (6): 1030-1044 
Kutchment, L.S. and A.N. Gelfan. 1996. The determination of the snowmelt rate and the meltwater outflow from a snowpack for modelling river runoff generation. Journal of Hydrology 179: 23-36

Legates, D. 1991. An evaluation of procedures to estimate monthly precipitation probabilities. Journal of Hydrology 122: 129-140

Legates, D. and G. McCabe Jr. 1999. Evaluating the use of "goodness-of-fit" measures in hydrologic and hydroclimatic model validation. Water Resources Research 35 (1): 233-241

Marks, D., Link, T., Winstral, A., and Garen, D. 2001. Simulating snowmelt processes during rain-on-snow over a semi-arid mountain basin. International Glaciology Society 32:195-202

McGrew, J.C. and C.B. Monroe. 2000. Statistical problem solving in geography. McGraw Hill, Boston.

Miles, E., A. Snover, A. Hamlet, B. Callahan, and D. Fluharty. 2000. Pacific Northwest regional assessment: The impacts of climate variability and climate change on the water resources of the Columbia River Basin. Journal of the American Water Resources Association 36 (2): 399-420

Mote, P.W., E.A. Parson, A.F. Hamlet, W.S. Keeton, D. Lettenmaier, N. Mantua, E.L. Miles, D.W. Peterson, D.L. Peterson, R. Slaughter, and A.K. Snover. 2003. Preparing for climate change: The water, salmon, and forests of the Pacific Northwest. Climatic Change 61: 45-88

Nash, J.E. and J.V. Sutcliffe. 1970. River flow forecasting through conceptual models. Journal of Hydrology. 10: 282-290

Natural Resources Conservation Service. 1997. Oregon STATSGO Soil GIS Data Set. http://www.ncgc.nrcs.usda.gov/branch/ssb/products/statsgo/data/or.html. Accessed October 2004.

Natural Resources Conservation Service. 2004. Oregon Snow Survey Program. http://www.or.nrcs.usda.gov/snow/. Accessed October 2004.

Omemik, J.M. 1987. Ecoregions of the conterminous United States. Map supplement (scale 1:7,500,000) (map now updated - see U.S. EPA 1995). Annals of the Association of American Geographers 77 (1): 118-125

Oregon Climate Service. 2005. Oregon climate data. http://www.ocs.oregonstate.edu/index.html. Accessed March 2005. 
Oregon Department of Fish and Wildlife (ODFW). 1990. Clackamas River, Willamette River Subbasin, salmon and steelhead production plan. Columbia Basin System Planning, Portland

Parsons, R. 1978. Soil-geomorphology relations in the mountains of Oregon, U.S.A. Geoderma 21: 25-39

Payne, J.T., A.W. Wood, A.F.Hamlet, R.N. Palmer, D.P. Lettenmaier. 2004. Mitigating the effects of climate change on the water resources of the Columbia Basin. Climatic Change 62: 233-256

Portland General Electric (PGE). 2003. About PGE. http://www.portlandgeneral.com. Accessed April 2004.

Price, L. 1981. Mountains and man: A study of process and environment. University of California Press, Berkeley

Regional Ecosystem Office. 2003. Watershed boundaries (GIS data). http://www.reo.gov. Accessed October 2004

Regonda, K.S., Rajagopalan, B., Clark, M., and Pitlick, J. 2005. Seasonal shifts in hydroclimatology over the Western United States. Journal of Climate 18: 372-384

Schneider, S. H. 1997. Laboratory Earth. Harpercollins, New York

Seidel, K., C. Ehrler, J. Martinec. 1998. Effects of climate change on water resources and runoff in an alpine basin. Hydrological Processes 12:1659-1669

Semadeni-Davies, A. 1997. Monthly snowmelt modelling for large-scale climate change studies using the degree day approach. Ecological Modelling 101: 303323

Service, R. 2004. As the West goes dry. Science, 303: 1124-1127

Shelton, M.L. 1999. Climate change and future hydroclimate for the upper Crooked River, Oregon. Physical Geography 20 (1): 14-26

Sherrod, D.R., S.E. Ingebritsen, J.M. Curless, T.E.C. Keith, N.M. Diaz, T.G. Deroo, and S.L. Hurlocker. 1996. Water, rocks, and woods - A field excursion to examine the geology, hydrology, and geothermal resources in the Clackamas, North Santiam, and McKenzie River drainages, Cascade Range, Oregon.Oregon Geology 58: 103-124

Singh, P., and L. Bengtsson. 2004. Hydrological sensitivity of a large Himalyan basin to climate change. Hydrological Processes 18: 2363-2385 
Spatial Climate Analysis Service. 2004. PRISM climate data. http://www.ocs.orst.edu/prism/. Accessed November 2004.

Stewart, I.T., D.R. Cayan, M.D. Dettinger. 2005. Changes toward earlier streamflow timing across western America. Journal of Climate 18: 1136-1155

StreamNet. 2004. Fisheries data for the Pacific Northwest. http://www.streamnet.org. Accessed February 2005.

Stonefelt, M., Fontaine, T., and Hotchkiss, R. 2000. Impacts of climate change on water yield in the Upper Wind River Basin. Journal of the American Water Resources Association 36 (2):321-336

Tague, C. and G.E. Grant. 2004. A geological framework for interpreting the low flow regimes of Cascade streams, Willamette River Basin, Oregon. Water Resources Research 40 (4): W043031-W043039

Taylor, B. 1999. Salmon and steelhead runs and related events of the Clackamas River Basin - A historical perspective. Portland General Electric Publication

The League of Women Voters. 2002. Drinking water in Clackamas County. http://home.teleport.com/ lwvwcc/Water\%20Study1.htm. Accessed April 2004.

U.S. Environmental Protection Agency (EPA). 1995. Level III Ecoregions of the continental United States (revision of Omernik 1987). NHEERL, Corvallis, OR.

U.S. Geological Survey. 1994. Ground water atlas of the United States - Segment 7. Hydrologic Investigations Atlas 730-H. Reston, VA.

U.S. Geological Survey. 1999. National land cover data set (1992). http://landcover.usgs.gov/natllandcover.asp. Accessed October 2004

U.S. Geological Survey - EROS Data Center. 1999. National elevation data. http://gisdata.usgs.net/NED/default.asp. Accessed October 2004

U.S. Geological Survey - Oregon Water Resources. 2004. Stream flow gage information. http://waterdata.usgs.gov/or/nwis/sw. Accessed October 2004

U.S. Global Change Research Program (USGCRP). 2000. The U.S. national assessment of the potential consequences of climate variability and change. http://www.usgcrp.gov/usgcrp/nacc/default.htm. Accessed May 2005

Van Katwijk, V., Rango, A., and Childress, A. 1993. Effect of simulated climate change on snowmelt runoff modeling in selected basins. Water Resources Bulletin 29 (5): 755-765 
Viviroli, D., and R. Weingartner. 2004. The hydrological significance of mountains: from regional to global scale. Hydrology and Earth System Sciences 8 (6): 10161029

Whittig, L., V. Kilmer, R. Roberts, and J. Cady. 1956. Characteristics and genesis of Cascade and Powell soils of northwestern Oregon. Proceedings of Soil Science Society of America 20: 226-231

Wigley, T.M., and P.D. Jones. 1985. Influences of precipitation changes and direct $\mathrm{CO}_{2}$ effects on streamflow. Nature 314: 149-152

$\mathrm{Xu}, \mathrm{C} .-\mathrm{Y}$., and V.P. Singh. 2004. Review on regional water resources assessment models under stationary and changing climate. Water Resources Management 18: 591-612 


\section{APPENDIX A: HYDROLOGIC MODEL CODE}

Note: This source code is written in Visual Basic for Applications (VBA) to run with Microsoft Access software with the DAO 2.5/3.51 Objects library. It requires tables that contain input information including soils, geology, and land cover information for each cell of the study area and input climate data (precipitation, temperature, and dew point) for each cell of the study area and month of the simulation.

\section{Function HydroModelCCO}

'This model simulates hydrologic processes over a distributed area in the Upper 'Clackamas Basin. It requires input climate, physiographic, and soils data for each study 'cell from the study area grid. It outputs a number of parameters, including runoff, 'evapotranspiration, snow pack, and soil moisture for each study cell for each month and year that the assessment is run.

'It is based on the Struma River Model, which was designed for a climate assessment in Bulgaria and uses a Thorthwaite Soil Water Balance approach.

'David Graves, Graduate Student - Portland State University, Geography Program $2004 / 2005^{\prime}$

Dim dbs As Database

'Define climate change variables

Dim ccmodel As String, adjclimate As Recordset, adjtemp As Double, adjppt As Double, adjtemp2, adjppt2 As Double

'Define miscellaneous variables

Dim status As String, PrecipTable As String, DewPointTable As String, TempTable As String

Dim LastMonthTable As String, ThisMonthTable As String, deltable As String, tdf As TableDef

'Define progress bar variables

Dim Progress As Integer, Prevprogress As Integer, TotalCount As Long, CurrentCount As Long, varReturn As Variant, strMsg As String

'Define module temporal variables

Dim BegYear As Integer, EndYear As Integer, curyear As Integer, CurYearSt As String, CurYearStb As String, curmonth As Integer, curmonthSt As String, MonthCount As Integer, LastMonthSt As String, LastMonthNum As Integer

'Define module spatial variables

Dim cellID As Integer, lastcell As Integer 
'Define input data variables

Dim avgtemp As Recordset, DewPoint As Recordset, Precip As Recordset, Soils As

Recordset, LastMonth As Recordset

Dim thismonth As Recordset, openwatercover As Recordset, avtemp As Double, dpt

As Double, ppt As Double, InitSoil As Recordset

Dim relhumid As Double, FC As Double, SCN As Double, SCNWet As Double, SCNDry As Double, scnadj As Double

Dim SnowMeltRate As Double, SnowMeltSet As Recordset, lakecover As Double, DaylightCof As Double, ForestProp As Double

Dim Geology As Recordset, GeolClass As Double

'Define output data variables

Dim ThisMonthOutput As Recordset

Dim snowpack As Double, soilmoist As Double, drunoff As Double, irunoff As

Double, trunoff As Double

Dim snowfall As Double, rainfall As Double, snowmelt As Double, raininfilt As

Double, totalinfilt As Double

Dim potevap As Double, actevap As Double, snowonlake As Double, rainsnowmelt

As Double

'Define temporary equation variables

Dim snowpct As Double, soildef As Double, soilsurp As Double, DaysMonth As

Integer

'Define tuning (calibration) variables. Note: may need to add critical melt temp to this Dim Legatescof As Double, SnowMeltCof As Double, IndirProp As Double,

PanEvapCof As Double, DecJanMult As Double

Dim snowdrunoff As String, SnowMeltTemp As Integer, Rainonsnowcof As Double, Drunoffcof As Double, GeologyProp As Double

Dim BaseFlow As String, BaseFlowSpecial As String, BaseFlowQuant As Double, BaseFlowProp As Double, tuningvars As Recordset, totalruns As Integer, currentrun As Integer

'Establish current database as the workspace.

Set $\mathrm{dbs}=$ CurrentDb()

'Set tuning (calibration) variables

'Initital Values: Legates $=1.61$, SnowMeltCof $=1$, IndirProp $=0.2$,

'PanEvap $=0.75$, snowdrunoff $=$ "n", baseflow $=$ "n"

'SnowMeltTemp $=0$, drunoffCof $=1$

'Set up progress bar and its variables

totalruns $=4$ 
currentrun $=0$

'Delete existing calibrate tables before running application

With dbs

For Each tdf In .TableDefs

If tdf.Name Like "Calibrate*" Then

deltable $=$ tdf.Name

DoCmd.DeleteObject acTable, deltable

End If

Next tdf

End With

'Loop through multiple runs for tuning purposes

'Do Until currentrun = totalruns

'currentrun = currentrun +1

'If currentrun $=1$ Then ccmodel $=$ "had2020"

'If currentrun $=2$ Then ccmodel $=$ "had2080"

'If currentrun $=3$ Then ccmodel $=" c \operatorname{cc} 2020 "$

'If currentrun $=4$ Then ccmodel $=$ "ccc2080"

ccmodel = "had2080"

currentrun $=1$

'Run batch mode to read input tuning variables and then output results for each run Set tuningvars = dbs.OpenRecordset("SELECT * FROM input_tuningvars where runcount $=1 ; "$ )

'get tuning values for this run from lookup table

Legatescof $=$ tuningvars!Legatescof 'Affects precip (snow vs. rain)

SnowMeltTemp = tuningvars!SnowMeltTemp 'Average Monthly Temperature at which snow begins to melt

SnowMeltCof $=$ tuningvars $!$ SnowMeltCof 'Rate of snow melt

Drunoffcof = tuningvars! Drunoffcof 'Multiplier of direct runoff

snowdrunoff = tuningvars! snowdrunoff 'Does direct runoff occur over snow?(if not, then rain percolates through snow pack to ground water and no rain-on-snow melting occurs)

Rainonsnowcof $=$ tuningvars!Rainonsnowcof 'If snowdrunoff $=y$, then what proportion of the $\mathrm{dr}$ melts as snow also?

PanEvapCof = tuningvars!PanEvapCof 'Estimation of ratio of potential evapotransipiration from groud/veg evapotranspiration to pan evaporation

IndirProp = tuningvars!IndirProp 'Monthly proportion of excess soil water (above field capacity) running out of basin

BaseFlow = tuningvars!BaseFlow 'Is there a lower layer groundwater baseflow that occurs year-round irrespective of the soil moisture surplus? If so, what is the amount (\% of soil moisture below field capacity)? 
BaseFlowProp = tuningvars!BaseFlowProp 'If baseflow $=y$, then what pct of the lower level base flow runs off each month (in addition to surplus indirect runoff)?

DecJanMult = tuningvars!DecJanMult 'Multiplier of direct runoff coefficient for the months of December and January, when intense rainfall events are more common

BaseFlowSpecial = tuningvars!BaseFlowSpecial 'Is base flow adjusted to increase after soil surplus is depleted and soil moisture lowers?

GeologyProp = tuningvars!GeologyProp 'Weighs the relative importance of cell geology on indirect vs. base flow $(2=$ total influence, $1=$ no influence $)$ 'enter number of cells in grid lastcell $=1264$

'On the first run, user is prompted to enter the beginning and end years that the simulation will be run for and 'checks to make sure that years are entered correctly

If currentrun $=1$ Then

status $=$ "n"

Do Until status $=$ "y"

BegYear = InputBox("Enter the first year to be run (1971-2000)")

EndYear = InputBox("Enter the last year to be run (1971-2000)")

If EndYear >= BegYear Then status $=$ " $y "$

Else

MsgBox ("First year must be earlier or the same as the ending year (click OK to continue)")

End If

Loop

status $=$ "n"

Do Until status $=" y "$ Then

If EndYear > 2000 Or EndYear < 1971 Or BegYear $>2000$ Or BegYear $<1971$

MsgBox ("Years must be between 1971 and 2000 (click OK to continue)")

BegYear = InputBox ("Enter the first year to be run (1971-2000)")

Else

EndYear = InputBox ("Enter the last year to be run (1971-2000)")

status $=" y "$

End If

Loop

End If

'Establish current database as the workspace. 
Set $\mathrm{dbs}=$ CurrentDb()

'Delete existing output tables before running application

With dbs

For Each tdf In .TableDefs

If tdf.Name Like "Output*" Then

deltable $=$ tdf.Name

DoCmd.DeleteObject acTable, deltable

End If

Next tdf

End With

'Set up progress bar and its variables

TotalCount $=($ EndYear - BegYear +1$) * 12$

CurrentCount $=0$

Progress $=0$

Prevprogress $=0$

strMsg = "Processing " \& TotalCount \& " months"

varReturn = SysCmd(acSysCmdInitMeter, strMsg, 100)

'Subtract 2 from CurYear since model works with water year, so year 1971 starts in Oct 1970 ,

'1971-2 = 1969, and 1 will be added at start of loop to equal 1970

curyear $=$ BegYear -2

'Run hydrologic model for current year'

Do Until curyear $=$ EndYear

curyear $=$ curyear +1

CurYearSt $=$ curyear

'Start model in October for first year only

If curyear $=$ BegYear -1 Then

curmonth $=9$

Else

curmonth $=0$

End If

'Set up tables to query for this year

PrecipTable = "Input_C_ppt" + CurYearSt

DewPointTable = "Input_C_dpt" + CurYearSt

TempTable = "Input_C_avtemp" + CurYearSt 
'Loop through each month of the year

Do Until curmonth $=12$ Or $($ curyear $=$ EndYear And curmonth $=9$ )

'Set up variables to show current and last month as both an integer and a string

'If the current month is January then the last month is set to December

'Month strings need to be two digits to match fields in input tables, so when

'month number is single digit, a 0 is added to the month string (ex: January is " 01 " not "1")

curmonth = curmonth +1

curmonthSt $=$ curmonth

If curmonth $<10$ Then curmonthSt $=$ " 0 " + curmonthSt

LastMonthNum $=$ curmonth -1

If curmonth $=1$ Then LastMonthNum $=12$

LastMonthSt $=$ LastMonthNum

If LastMonthNum $<10$ Then LastMonthSt $=$ "0" + LastMonthSt

'Set up table to query for last month's output data

LastMonthTable = "Output_" + CurYearSt + LastMonthSt

'If month is january, then need to look in previous year for last month's data

If curmonth $=1$ Then

CurYearStb $=$ (curyear -1$)$

LastMonthTable = "Output_" + CurYearStb + LastMonthSt

End If

'Create new table to store this month's outputs

dbs.Execute "CREATE TABLE Output_" \& CurYearSt \& curmonthSt \& " (cellID long, rainfall double, snowfall double, snowmelt double, raininfilt double, totalinfilt double, potevap double, actevap double, drunoff double, irunoff double, trunoff double, snowpack double, soilmoist double);"

ThisMonthTable $=$ "Output_" + CurYearSt + curmonthSt

Set ThisMonthOutput $=$ dbs. OpenRecordset $($ ThisMonthTable)

'******** RAINFALL/SNOWFALL COMPONENT *******
cellID $=0$

Do Until celliD = lastcell

cellID $=$ cellID +1

'Get precipitation and temperature for month 1 of this year 
Set Precip = dbs.OpenRecordset("SELECT " \& PrecipTable \& ".ppt" \& curyear \& curmonthSt \& "_MEAN AS expr1 FROM " \& PrecipTable \& " WHERE (((" \& Precip Table \& ".CellID)=" \& celliD \& "));")

'get precipitation in centimeters

ppt $=$ Precip!Expr $1 / 1000$

Set avgtemp $=$ dbs.OpenRecordset $($ "SELECT " \& TempTable \& ".avtemp" \& curyear \& curmonthSt \& ".MEAN AS exprl FROM " \& TempTable \& " WHERE (((" \& TempTable \& ".CelliD) $=$ " \& cellID \& "));")

'get temperature in degrees celsius

avtemp $=$ avgtemp!Exprl $/ 100$

'ADJUST FOR CLIMATE CHANGE ASSESSMENT:

'Dim ccmodel As String, adjclimate As Recordset, adjtemp as Double, adjppt as

Double, adjtemp2, adjppt2 as double

'Query for results from Global Climate Model for this month and period

Set adjclimate = dbs.OpenRecordset("SELECT * FROM CCAssess_" \& ccmodel \&

" WHERE ((month = " \& curmonth \& "));")

adjtemp $=$ adjclimate!temp

adjppt $=$ adjclimate!ppt

'Query for differences between 1961-1990 period (used as a baseline for GCMs) and 1971-2000 period(used in this assessment)

Set adjclimate $=$ dbs.OpenRecordset("SELECT * FROM CCAssess_6190Adjust

WHERE ((month = " \& curmonth \& "));")

adjtemp $2=$ adjclimate!temp

adjppt $2=$ adjclimate!ppt

'Adjust temperatures for climate period in this assessment

avtemp $=$ avtemp + adjtemp - adjtemp2

$\operatorname{adjppt} 2=1 /(1+\operatorname{adjppt} 2)$

'Adjusts ppt to 1961-90 period

ppt $=$ ppt $*$ adjppt 2

'Adjusts ppt to climate period in this assessment ppt $=p p t+($ adjppt * $(p p t / 100))$

'Legates Equation to determine \% of precipitation occuring as snow snowpct $=\left(\operatorname{Int}\left(100 /\left(\left(\left(1.35^{\wedge} \text { avtemp }\right)^{*}\right.\right.\right.\right.$ Legatescof $\left.\left.\left.)+1\right)\right)\right) / 100$ 
'calculate snow/rain variables

snowfall $=\mathrm{ppt}^{*}$ snowpct

rainfall $=$ ppt $*(1-$ snowpct $)$

'adjust for any snow fall that falls on open water (this is automatically converted to rainfall)

Set openwatercover $=$ dbs. OpenRecordset("SELECT

Input_CellOpenWaterPct.CellID, Input_CellOpenWaterPct.[LandCover\%] FROM

Input_CellOpenWaterPct WHERE (((Input_CellOpenWaterPct.CellID) $="$ \& cellID \& "));")

lakecover $=$ openwatercover! [landcover\%]

snowonlake $=$ lakecover $*$ snowfall

snowfall $=$ snowfall - snowonlake

rainfall $=$ rainfall + snowonlake

'query for current snowpack (if first month of simulation, then 0 because it's

October)

If CurrentCount $=0$ Then

snowpack $=0$

Else

Set LastMonth $=$ dbs.OpenRecordset("SELECT " \& LastMonthTable \&

".snowpack FROM " \& LastMonthTable \& " WHERE (((" \& LastMonthTable \&

".CelliD)=" \& celliD \& "));")

snowpack $=$ LastMonth!snowpack

End If

'update snowpack to include current snowfall

snowpack $=$ snowpack + snowfall

'concatenate varables to two decimals (detail $=1 / 100$ of centimeter)

snowfall $=$ snowfall $* 100$

snowfall $=\operatorname{Int}($ snow fall $)$

snowfall $=$ snowfall $/ 100$

rainfall $=$ rainfall $* 100$

rainfall $=$ Int(rainfall $)$

rainfall $=$ rainfall $/ 100$

snowpack $=$ snowpack $* 100$

snowpack $=\operatorname{Int}($ snowpack $)$

snowpack $=$ snowpack $/ 100$

'add new record to output table for this cell, and update snow and rain variables With ThisMonthOutput 


$$
\begin{aligned}
& \text { !cellID = celliD } \\
& \text { !snowfall = snowfall } \\
& \text { !rainfall = rainfall } \\
& \text { !snowpack = snowpack } \\
& \text {.Update }
\end{aligned}
$$

End With

'Loop rainfall/snowfall component to next cell

Loop

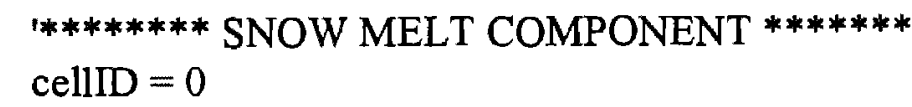

Do Until cellID $=$ lastcell

$$
\text { cellID }=\text { cellID }+1
$$

'query for current snowpack

Set thismonth = dbs.OpenRecordset("SELECT " \& ThisMonthTable \&

".snowpack, " \& ThisMonthTable \& ",rainfall FROM " \& ThisMonthTable \& "

WHERE (((" \& ThisMonthTable \& ".CellID) $="$ \& cellID \& "));")

snowpack $=$ thismonth!snowpack

rainfall $=$ thismonth!rainfall

If snowpack $=0$ Then

snowmelt $=0$

Else

'get snow melt rate for this cell

Set SnowMeltSet $=$ dbs.OpenRecordset $($ "SELECT

Input_SnowMeltRate.SnowMeltRate FROM Input_SnowMeltRate WHERE (((Input_SnowMeltRate.CellD) $="$ \& cellD \& "));")

SnowMeltRate $=$ SnowMeltSet $!$ SnowMeltRate

Next, estimate energy-driven snow melt with degree day equation:

'get temperature in degrees celsius

Set avgtemp = dbs.OpenRecordset("SELECT " \& TempTable \& ".avtemp" \& curyear \& curmonthSt \& "_MEAN AS exprl FROM " \& TempTable \& " WHERE

(((" \& TempTable \& ".CelliD) $="$ \& cellID \& "));")

avtemp $=$ avgtemp!Expr $1 / 100$

'ADJUST FOR CLIMATE CHANGE ASSESSMENT: 
'Query for results from Global Climate Model for this month and period

Set adjclimate $=$ dbs.OpenRecordset("SELECT * FROM CCAssess_" \& ccmodel \&

" WHERE $(($ month $=$ " \& curmonth \& "));")

adjtemp $=$ adjclimate!temp

'Query for differences between 1961-1990 period (used as a baseline for GCMs) and 1971-2000 period(used in this assessment)

Set adjclimate $=$ dbs.OpenRecordset("SELECT * FROM CCAssess_6190Adjust

WHERE $(($ month $=$ " \& curmonth \& "));")

adjtemp $2=$ adjclimate!temp

'Adjust temperatures for climate period in this assessment avtemp $=$ avtemp + adjtemp - adjtemp2

'Determine number of days in month

If curmonth $=1 \mathrm{Or}$ curmonth $=3$ Or curmonth $=5$ Or curmonth $=7$ Or curmonth

$=8$ Or curmonth $=10$ Or curmonth $=12$ Then

DaysMonth $=31$

Elself curmonth $=4$ Or curmonth $=6$ Or curmonth $=9$ Or curmonth $=11$ Then

DaysMonth $=30$

ElseIf curmonth $=2$ Then

DaysMonth $=28.25$

End If

'Degree day equation to determine snow melt

snowmelt $=\left(\right.$ SnowMeltRate ${ }^{*}$ SnowMeltCof $) *($ avtemp - SnowMeltTemp $) *$

DaysMonth

If snowmelt $<0$ Then

snowmelt $=0$

End If

'Subtract snow melt for month from existing snow pack

If snowmelt $>$ snowpack Then snowmelt $=$ snowpack

snowpack $=$ snowpack - snowmelt

If snowpack $<0$ Then snowpack $=0$

End If

'concatenate varables to two decimals (detail $=1 / 100$ of centimeter)

snowmelt $=$ snowmelt $* 100$

snowmelt $=\operatorname{Int}($ snowmelt $)$

snowmelt $=$ snowmelt $/ 100$

snowpack $=$ snowpack $* 100$ 
snowpack $=$ Int(snowpack $)$

snowpack $=$ snowpack $/ 100$

'update snowmelt, snowpack information here

Set ThisMonthOutput $=$ dbs. OpenRecordset $($ "SELECT CellID, Snowpack, snowmelt FROM " \& ThisMonthTable \& " WHERE ((CellID=" \& cellID \& "));")

With ThisMonthOutput

.Edit

!snowmelt $=$ snowmelt

!snowpack $=$ snowpack

.Update

End With

'Loop snowmelt component to next cell

Loop

\section{******** INFILTRATION/DIRECT RUNOFF COMPONENT}

cellID $=0$

Do Until celliD = lastcell

cellID $=$ cellID +1

'query for current snowpack and rainfall

Set thismonth $=$ dbs.OpenRecordset("SELECT " \& ThisMonthTable \& ".snowpack, " \& ThisMonthTable \& ".rainfall, " \& ThisMonthTable \& ".snowmelt FROM " \& ThisMonthTable \& " WHERE (( $" \&$ ThisMonthTable \& ".CellD)=" \& cellID \& "));")

snowpack $=$ thismonth!snowpack

rainfall $=$ thismonth!rainfall

snowmelt $=$ thismonth!snowmelt

'query for current soil moisture (if first month of simulation, then calculate based on average october 1st soil moisture)

If CurrentCount $=0$ Then

Set InitSoil = dbs.OpenRecordset("SELECT Input_InitialSoilMoisture.SoilMoist FROM Input_InitialSoilMoisture WHERE (Input_InitialSoilMoisture.CellID =" \& cellID \& ");")

soilmoist $=$ InitSoil! soilmoist

Else

Set LastMonth = dbs.OpenRecordset("SELECT " \& LastMonthTable \&

".soilmoist FROM " \& LastMonthTable \& " WHERE (((" \& LastMonthTable \&

".CellD)=" \& celliD \& "));")

soilmoist $=$ LastMonth!soilmoist

End If 
'If snowpack exists and Rain on Snow is assumed to percolate and infiltrate soil then no direct runoff occurs...

If snowpack $>0$ And snowdrunoff $=$ " $n$ " Then

raininfilt $=$ rainfall

drunoff $=0$

totalinfilt $=$ rainfall + snowmelt

End If

'Otherwise, calculate direct runoff vs. infiltration based on soil curve number

If snowpack $=0$ Or snowdrunoff $=$ " $y$ " Then

Set Soils = dbs.OpenRecordset("SELECT Input_CellSoils.SoilCurveNumber FROM Input_CellSoils WHERE ((Input_CellSoils.CellID)=" \& cellID \& ");")

$\mathrm{SCN}=$ Soils! SoilCurveNumber

'Soil Curve Numbers are also determined for wet and dry conditions

SCNDry $=(4.2 * \mathrm{SCN}) /(10-(0.058 * \mathrm{SCN}))$

$\mathrm{SCNWet}=(23 * \mathrm{SCN}) /(10+(0.13 * \mathrm{SCN}))$

'SCN adjusted based on the month of the year to estimate soil moisture conditions

Note: Took this out, cite article on august infiltration at Oregon test sites

'average soil moisture conditions:

'If CurMonth $=10$ Or CurMonth $=3$ Or CurMonth $=4$ Or CurMonth $=5$ Then scnadj $=$ SCN

'dry soil moisture conditions:

'ElseIf CurMonth $>5$ And CurMonth $<10$ Then

'scnadj $=(\mathrm{SCN}+\mathrm{SCNDry}) / 2$

'wet soil moisture conditions:

'ElseIf CurMonth $=11$ Or CurMonth $=12$ Or CurMonth $=1$ Or CurMonth $=2$ Then

'scnadj $=(\mathrm{SCN}+\mathrm{SCNWet}) / 2$

'End If

'temporarily convert precipitation to inches for the equation rainfall $=$ rainfall $/ 2.54$

'Old Soil Curve Number Equation 'drunoff $=(($ rainfall $-(0.2 *(1000 /$ SCNAdj $))) *($ rainfall $-(0.2 *(1000 /$ SCNAdj $))) /($ rainfall $+(0.8 *(1000 /$ SCNAdj $)))$ 
'Adjust for Tim Lake cell that isn't counted in results

If $\operatorname{scnadj}=100$ Then scnadj $=99$

'Ferguson Soil Curve Number Equation

'drunoff $=-0.095+(0.208 *$ rainfall $) /\left(((1000 / \text { scnadj })-10)^{\wedge} 0.66\right)$

drunoff $=(-0.095+(0.208 *$ rainfall $)) /\left(((1000 / \text { scnadj })-10)^{\wedge} 0.66\right)$

'** March edits begin here

1***Adjust direct runoff proportion during the months of December and January, when high intensity precipitation events are more common

If curmonth $=12$ Or curmonth $=1$ Then Drunoffcof $=$ Drunoffcof $*$ DecJanMult

'Optionally, adjust direct runoff by tuning coefficient as long as this 'doesn't increase it greater than the incoming rainfall

If rainfall $>$ (drunoff * Drunoffcof) Then

drunoff $=$ drunoff $*$ Drunoffcof

Else

drunoff $=$ rainfall

End If

'Reset drunoffcof

If curmonth $=12$ Or curmonth $=1$ Then Drunoffcof $=$ Drunoffcof $/$ DecJanMult

'convert direct runoff and rainfall back to centimeters

drunoff $=$ drunoff $* 2.54$

rainfall $=$ rainfall $* 2.54$

'reset variable

rainsnowmelt $=0$

If drunoff $<0$ Then drunoff $=0$

'If snowpack exists then additional direct runoff comes out of the snow

'because of rain-on-snow melting. This is assumed to be an additional $100 \%$ of the total direct runoff.

'This is included as snowmelt but does not infiltrate the soil because it runs off 'as part of the direct runoff.

If snowpack $>0$ Then

If (Rainonsnowcof* drunoff) < snowpack Then rainsnowmelt $=$ drunoff $*$ Rainonsnowcof

Else rainsnowmelt $=$ snowpack 


$$
\begin{aligned}
& \quad \text { End If } \\
& \text { Else } \\
& \text { rainsnowmelt }=0 \\
& \text { End If } \\
& \text { snowmelt }=\text { snowmelt }+ \text { rainsnowmelt } \\
& \text { snowpack = snowpack }- \text { rainsnowmelt } \\
& \text { raininfilt }=\text { rainfall }- \text { drunoff } \\
& \text { totalinfilt }=\text { raininfilt }+ \text { snowmelt }- \text { rainsnowmelt } \\
& \text { drunoff }=\text { drunoff }+ \text { rainsnowmelt }
\end{aligned}
$$

End If

'** March edits end here

'concatenate varables to two decimals (detail $=1 / 100$ of centimeter)

$$
\begin{aligned}
& \text { drunoff }=\text { drunoff } * 100 \\
& \text { drunoff }=\text { Int }(\text { drunoff }) \\
& \text { drunoff }=\text { drunoff } / 100 \\
& \text { raininfilt }=\text { raininfilt } * 100 \\
& \text { raininfilt }=\text { Int }(\text { raininfilt }) \\
& \text { raininfilt }=\text { raininfilt } / 100 \\
& \text { totalinfilt }=\text { totalinfilt } * 100 \\
& \text { totalinfilt }=\text { Int (totalinfilt }) \\
& \text { totalinfilt }=\text { totalinfilt } / 100
\end{aligned}
$$

'Update direct runoff and infiltration calculations to output table Set ThisMonthOutput = dbs. OpenRecordset("SELECT CellID, soilmoist, snowpack, snowmelt, drunoff, raininfilt, totalinfilt FROM " \& ThisMonthTable \& " WHERE ((CellID=" \& cellID \& "));")

With ThisMonthOutput

$$
\text { .Edit }
$$$$
\text { !drunoff = drunoff }
$$$$
\text { !raininfilt }=\text { raininfilt }
$$$$
\text { !totalinfilt }=\text { totalinfilt }
$$$$
\text { !soilmoist }=\text { soilmoist }+ \text { totalinfilt }
$$$$
\text { !snowpack }=\text { snowpack }
$$$$
\text { !snowmelt }=\text { snowmelt }
$$$$
\text { .Update }
$$

End With

'Loop infiltration/direct runoff component to next cell Loop 
******** POTENTIAL/ACTUAL EVAPORATION COMPONENT

cellID $=0$

Do Until celliD = lastcell

cellID $=$ cellID +1

'Potential Evaporation is determined with the Ivanov equation:

'get temperature in degrees celsius

Set avgtemp = dbs.OpenRecordset("SELECT " \& TempTable \& ".avtemp" \& curyear \& curmonthSt \& ".MEAN AS expr1 FROM " \& TempTable \& " WHERE $(((" \&$ TempTable \& ".CelliD $)="$ \& cellID \& "));")

avtemp $=$ avgtemp!Expr $1 / 100$

\section{'ADJUST FOR CLIMATE CHANGE ASSESSMENT:}

'Query for results from Global Climate Model for this month and period Set adjclimate $=$ dbs.OpenRecordset("SELECT * FROM CCAssess_" \& ccmodel \&

" WHERE ((month = " \& curmonth \& "));")

adjtemp $=$ adjclimate!temp

'Query for differences between 1961-1990 period (used as a baseline for GCMs) and 1971-2000 period(used in this assessment)

Set adjclimate $=$ dbs.OpenRecordset("SELECT * FROM CCAssess_6190Adjust WHERE $(($ month $=$ " \& curmonth \& "));")

adjtemp2 $=$ adjclimate!temp

'Adjust temperatures for climate period in this assessment avtemp $=$ avtemp + adjtemp - adjtemp2

'get dew point in degrees celsius

Set DewPoint $=$ dbs.OpenRecordset("SELECT " \& DewPointTable \& ".dpt" \& curyear \& curmonthSt \& ".MEAN AS exprl FROM " \& DewPointTable \& " WHERE (((" \& DewPoint Table \& ".CellID $)="$ \& cellID \& "));") $\mathrm{dpt}=$ DewPoint $!$ Expr $1 / 100$

'calculate relative humidity based on average temperature and dew point relhumid $=(6.112 * \operatorname{Exp}((17.67 * \mathrm{dpt}) /(\mathrm{dpt}+243.5))) /(6.112 * \operatorname{Exp}((17.67 *$ avtemp) /(avtemp +243.5$))$ )

relhumid $=$ relhumid $* 100$ 
'Ivanov Equation (calculates $\mathrm{PE}$ as $\mathrm{mm} / \mathrm{month}$, then convert to $\mathrm{cm} / \mathrm{month}$ ): potevap $=-0.0018 *($ relhumid -100$) *($ avtemp +25$) *($ avtemp +25$)$

potevap $=$ potevap $/ 10$

'Adjust potential evaporation for pan and vegetation coefficients potevap $=$ potevap $*$ PanEvapCof

'Get proportion of this cell that is forested for transpiration estimation

Set SnowMeltSet $=$ dbs. OpenRecordset("SELECT Input_SnowMeltRate.ForestProp FROM Input_SnowMeltRate WHERE (((Input_SnowMeltRate.CellID)=" \& cellID \& "));")

ForestProp $=$ SnowMeltSet!ForestProp

Note assumption made here is that evapotranspiration in forested areas will be $25 \%$ higher

'on average than non-forested areas ( 1 vs. .8). No citation available yet but may 'look at article on effects of clear-cuts on flow for this and adjust. Total proportion 'should work out to be slightly less than Pan coefficient ( $90 \%$ of study area is forested)

'Several factors complicate these assumptions (forests increase transpiration, but higher

'forest albedos decrease evaporation, interception increases evaporation, especially as snow,

but trees can increase precipitation through fog drip effect...

'Adjust potential transpiration for monthly fraction of annual hours of daylight (from table

'in Dunne and Leopold on p. 141)

If curmonth $=1$ Then DaylightCof $=0.762$

If curmonth $=2$ Then DaylightCof $=0.774$

If curmonth $=3$ Then DaylightCof $=0.984$

If curmonth $=4$ Then DaylightCof $=1.086$

If curmonth $=5$ Then DaylightCof $=1.236$

If curmonth $=6$ Then DaylightCof $=1.254$

If curmonth $=7$ Then DaylightCof $=1.266$

If curmonth $=8$ Then DaylightCof $=1.164$

If curmonth $=9$ Then DaylightCof $=1.008$

If curmonth $=10$ Then DaylightCof $=0.912$

If curmonth $=11$ Then DaylightCof $=0.768$

If curmonth $=12$ Then DaylightCof $=0.786$

'Evapotranspiration equals \%forested * monthly ET rate + \%nonforested * .8 potevap $=$ potevap $*(($ ForestProp $*$ DaylightCof $)+((1-$ ForestProp $) * 0.8))$ 
'Actual Evaporation is determined with the Thornthwaite Soil Water Balance Method

'Query for field capacity of soil

Set Soils = dbs.OpenRecordset("SELECT Input_CellSoils.fieldcapacity_cm FROM Input_CellSoils WHERE ((Input_CellSoils.CellD) $=$ " \& cellID \& ");")

$\mathrm{FC}=$ Soils $!$ fieldcapacity_cm

'One cell falls in Timothy Lake and will not be used for output but needs to be calculated...

If $\mathrm{FC}=0$ Then $\mathrm{FC}=0.1$

'Query for current soil moisture

Set thismonth = dbs.OpenRecordset("SELECT " \& ThisMonthTable \& ".soilmoist FROM " \& ThisMonthTable \& " WHERE (((" \& ThisMonthTable \& ".CellID)=" \& cellID \& "));")

soilmoist $=$ thismonth!soilmoist

'Calculate soil moisture surplus/deficit

soilsurp = soilmoist $-\mathrm{FC}$

soildef $=$ FC - soilmoist

'If soilmoist $>=F C$ then $\mathrm{AE}=\mathrm{PE}$

'If soilmoist $<\mathrm{FC}$ then $\mathrm{AE}=\mathrm{PE}(\mathrm{SM} / \mathrm{FC})$

If soilsurp $>=0$ Then

'soil moisture surplus exists

'All potential evaporation occurs

actevap $=$ potevap

Else

'soil moisture deficit exists actevap $=$ potevap $*($ soilmoist $/ \mathrm{FC})$

End If

If actevap $<0$ Then actevap $=0$

If actevap $>$ soilmoist Then actevap $=$ soilmoist

soilmoist $=$ soilmoist - actevap

'concatenate varables to two decimals (detail $=1 / 100$ of centimeter)

soilmoist $=$ soilmoist $* 100$

soilmoist $=\operatorname{Int}($ soilmoist $)$

soilmoist $=$ soilmoist $/ 100$

potevap $=$ potevap $* 100$

potevap $=$ Int(potevap)

potevap $=$ potevap $/ 100$

actevap $=$ actevap $* 100$ 


$$
\begin{aligned}
& \text { actevap }=\operatorname{Int}(\text { actevap }) \\
& \text { actevap }=\text { actevap } / 100
\end{aligned}
$$

'Update soil moisture, potevap, and actevap to output table

Set ThisMonthOutput = dbs.OpenRecordset("SELECT CellID, soilmoist, drunoff, actevap, potevap FROM " \& ThisMonthTable \& " WHERE ((CellID=" \& cellID \& "));")

$$
\begin{aligned}
& \text { With ThisMonthOutput } \\
& \text {.Edit } \\
& \text { !soilmoist = soilmoist } \\
& \text { !potevap = potevap } \\
& \text { !actevap = actevap } \\
& \text {.Update } \\
& \text { End With }
\end{aligned}
$$

'Loop potential/actual evaporation component to next cell Loop

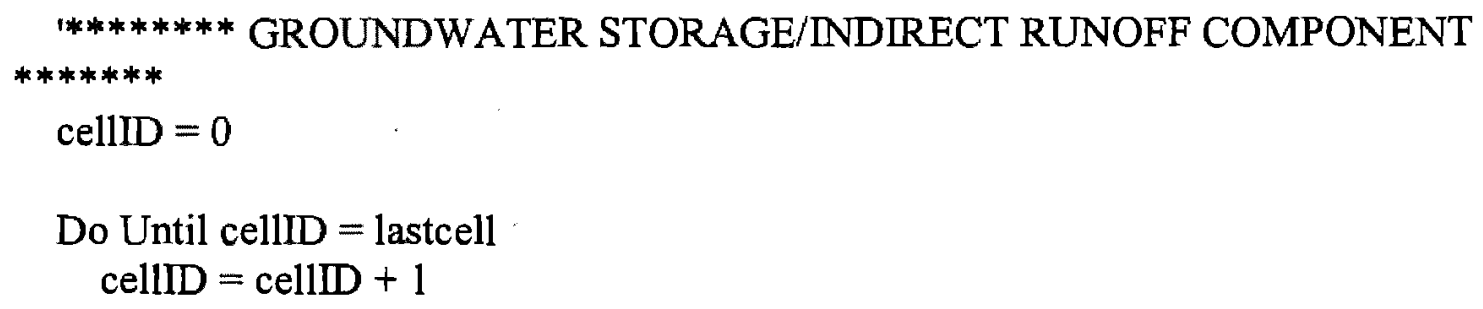

'Query for field capacity of soil

Set Soils = dbs.OpenRecordset("SELECT Input_CellSoils.fieldcapacity_cm FROM Input_CellSoils WHERE ((Input_CellSoils.CellID)=" \& cellID \& ");")

$\mathrm{FC}=$ Soils!fieldcapacity_cm

'Query for current soil moisture and previous direct runoff

Set thismonth = dbs.OpenRecordset("SELECT " \& ThisMonthTable \& ".soilmoist," \& ThisMonthTable \& ".drunoff FROM " \& ThisMonthTable \& " WHERE (((" \& ThisMonthTable \& ".CellID)=" \& cellID \& "));")

soilmoist $=$ thismonth!soilmoist

drunoff $=$ thismonth!drunoff

'Calculate soil moisture surplus/deficit

soilsurp = soilmoist - FC

soildef $=$ FC - soilmoist 
'Added modifications here based on cell geology. If cell geology is high cascade, then BaseFlow Prop is more important,

'if cell geology is western cascade, then IndirProp is more important. Rationale is that high cascade geology

'aquifers are more permeable and affect flow more, whereas western cascades aquifers are not, and are of less

'importance to river flow. A coefficient (geologyprop) is used to determine the relative influence, where $1=$

'no difference and $2=$ absolute difference.

'importance of these two factors.

'Dim Geology As Recordset, GeolClass As Integer

Set Geology = dbs.OpenRecordset("SELECT GeolClass FROM Input_CellGeology WHERE CellD = " \& cellID \& ";")

GeolClass $=$ Geology $!$ GeolClass

'Calculate Indirect Runoff from soil moisture excess:

'in this case indirect runoff includes both baseflow from ground water and 'delayed movement of surface water through the basin

If soilsurp $>0$ Then

'soilmoisture surplus exists and is available for runoff

inunoff $=$ soilsurp * IndirProp

'next two lines added for geology influence

If GeolClass $=1$ Then inunoff $=$ irunoff * $(2-$ GeologyProp $)$

If GeolClass $=0$ Then irunoff $=$ irunoff $*$ GeologyProp

If irunoff $>$ soilmoist Then irunoff $=(0.5 *$ soilmoist $)$

trunoff $=$ irunoff + drunoff

soilmoist $=$ soilmoist - irunoff

Else

irunoff $=0$.

trunoff $=$ drunoff

End If

'Optionally, if baseflow is included in model then calculate this as a proportion of field capacity (or total soil moisture if below FC), by

'representing a continuous flow from lower level ground water that isn't influenced

'excess soil moisture near surface

'Version 7: Optionally modified this to try to more closely symbolize aquifer recharge processes

'BaseFlowprop varies across a 10 point range, increasing as the soil moisture supply falls below field capacity

'to simulate the summer compensation of base flow from aquifers (vs. the winter recharge of aquifers) 


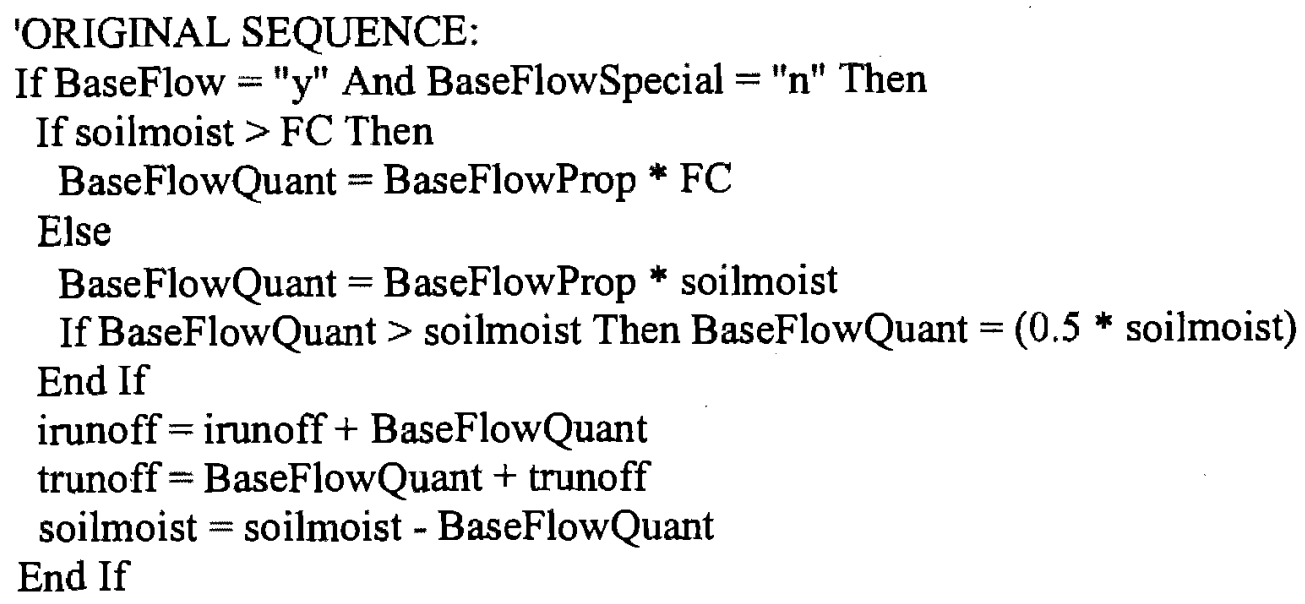

Update indirect runoff and total runoff to output table

Set ThisMonthOutput $=$ dbs. OpenRecordset("SELECT CellID, irunoff, trunoff, soilmoist FROM " \& ThisMonthTable \& " WHERE ((CellD=" \& cellID \& "));") 


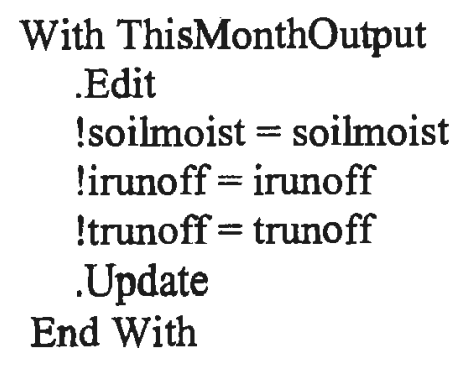

'Loop groundwater storage/indirect runoff component to next cell Loop

'Check to see if progress bar should be updated

CurrentCount $=$ CurrentCount +1

Progress $=($ CurrentCount $/$ TotalCount $) * 100$

If Progress $>$ Prevprogress Then

'Progress has been made so status bar should be updated varReturn $=$ SysCmd(acSysCmdUpdateMeter, Progress)

Prevprogress $=$ Progress

'Repaint the screen

DoCmd.RepaintObject acDefault

End If

'Loop to next month

Loop

'Loop to next year

Loop

Exit Function

End Function 